DEPARTMENT UF THE INTERIOR

UNITED STATES GEOLOGICAL SURVEY

CBARLEY 10. WALCOTT, ITRECTOE:

\title{
DESTRUCTIVE FLOODS IN THE UNITED STATES IN 1903
}

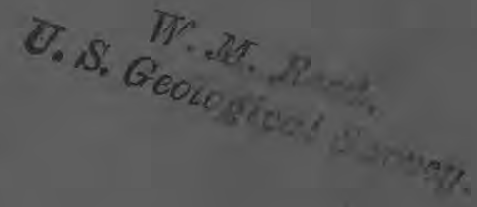

E. C. MURPHY

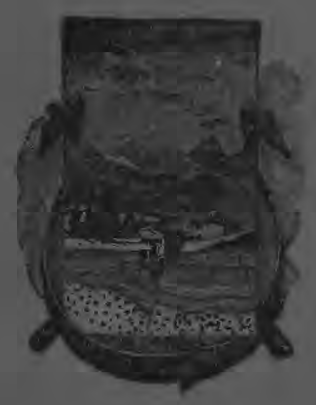

WASIINGTON

GOVERNMENT PRINTING OFFICE

1904

- TRÄNSFER CASE 


\section{PUBLICATIONS OF UNITED STATES GEOLOGICAL SURVEY.}

The publications of the United States Geological Survey consist of (1) Anmual Reports; (2) Monographs: (3) Professional Papers; (4) Bullotins; (5) Mineral Resources; (6) Water-Supply and Irrigation Papers; (n) Topogrsphic Atlas of United States, folios and separate sheots thereof; (8) Geologic Atlas of the United States, folios thereof. The classes numbered 2, 7, and 8 are sold at cost of publication; the others are distributed free. A circular giving complete lists may bes had on application.

The Professional Papers, Bulletins, and Water-supply Papers treat of a varioty of aubjects, and the total number issued is large. They have therefore been classifed into the following series: A, Deconomie geology; B, Deseriptive geology; C, Systernatic geology and paleontology; D, Petrography and mineralogy; E, Chemistry and physics; F, Geography; G. Miscellaneons; H, Forestry; I, Irrigation; J, Water storage; K, Pumping water; L, Quality of water; IF, General hydrographic investigations; $N$, Water power; $O$, Underground waters; $P$, Hydrographic progress reports.

The following Water-Supply Papers are out of stock, and can no longer be supplied: Nos. 1-16, 19, 20, $22,29-34,36,39,40,43,46,57-65,75$. Complete lists of pajers relating to water supply and allied subjects follow. (PP/=Professional Paper; $\mathrm{B}=\mathrm{Bullotin;}$ WS=Water-Supply Paper.)

\section{SERMES I-ITRLGATIOK.}

WS 2. Irrigation near Pheanix, Ariz., by A. P. Daris, 1897. 98 pg., 31 pls, and maps. WS 5. Irrigation praetics on the Great Plains, by E. B. Cowgill. 1897 . 39 pp., 11 pls.

WS 9. Irrigation near Groeley, Colo, by 1 avid Boyd. $189 \%$. 90 pp., 21 pls.

WS 10. Irrigation in Mesilla Valley, New Mexico, by F. C. Barkex. 1898 al pp., 11 pls.

WS 13. Irrigation system in Texas, by W. F. Hutson. 1898.68 pp., 10 pls.

WS 17. Irrigation neax Bakersfield, Cal., by C. E. Grumsky. 1899. 96 pp., 16 pls.

WS 18. Irrigation near Fresno, Cal., by C. E. Arunsky. 1898.94 pp., 14 pls.

WS 19. Irrigation near Merced, Cal., by C. E. Grunsky. 1899. $59 \mathrm{pp}$, 11 pls.

WS 23. Weter-right problems of Bighorn Mowntains, by Elwood Mead. 1899. 62 pp., 7 pls.

WS 3ะ. Water resources of Porto Rico, by H. M. Wilson. 1899.48 pp.y 17 pls. and maps.

WS 43. Conveyanes of water in irrigation canals, fiumes, and pipes, by Samuel Fortier. 1001. $86 \mathrm{pp}, 15 \mathrm{pls}$.

WS 70. Geology and water resources of the Patrick and Gashen Fole quadrangles, Wyoming, by G. I. Adams. $1962.50 \mathrm{pp}, 11 \mathrm{pls.}$

WS 71. Irxigatiun systoms of Texas, by T. U, Taylor. 1002. $12 \%$ pp. 9 pls

WS 74. Weter resources of the State of Colnrado, by A. I Fellows. 1902.151 pp., 14 pls.

WS 87. Irrigation in India (second edjtion), by H. M. Wilson. 1903.223 pp., 27 pls.

WS 93. Procendings of first conference of engineers of the reclamation service, with accompanying papers, compiled by F. H, Newell, chief engineer. 1004 . - pp.

The following papers also relate especially to irrigation: Irrigation in India, by H. M. Wilson, in Twelfth Annual, Pt. If; two papers on irrigation engineering, by H. M. Wilson, in Thirteenth Annual, Pt. III.

\section{SERIES J-WATER STORAGE.}

WS 33. Storage of wafer on Gila River, Arizona, by J. B. Lippincott. 1900. 08 pp, 33 pls. WS 40. The Austin dam, by Thomas U. Taylor, $1900.51 \mathrm{pp}, 16 \mathrm{pls}$.

WS 45. Water storage on Cache Creok, California, by A. E. Chandler. 1901. 48 pp., 10 pls.

WS 48. Physical chriateriatics of Kern River, California, by F. F. Olmsted, and Reconnaissance of Yuba River, California, by Marsden Manson. 1901. 57 pp., 8 pls.

WS 58. Storage of Water on Kings River, California, by J. B. Lippincott $1902.1(\mathrm{x}) \mathrm{pp}, 32 \mathrm{pls}$.

W' 68 . Water storage in Truckee Basin, California-Nevadn, by L. F. Taylor. 1202, 90 pp, 8 pls.

WS 73. Water storage on Salt River, Arizona, by A. P. Davis. 1902.54 pp., 25 pls.

WS 86. Storage repervoirs on Stony Creek, California, by Burt Cole. $190 \%$. 62 pp., 16 pls.

WS 89. Water recoureng of Salinas Valley, California, by Homer Hamlin. 1904, g1 pD., 12pls.

WS 13. Proceedings of first conference of engineers of tho reclamation gervice, with accompenying papers, compiled by F. H. Newell, chiof engineer. 1904. -pp.

The following paper alsa should be noted under this heading: Reservoirg for irrigation, by J. D. Schuyler, in Fighteenth Annual, Pt. IV.

IRA $96-9$

[Continued on third page of cover.] 


\title{
DESTRUCTIVE FLOODS IN THE UNITED STATES IN 1903
}

BY

\author{
E. O. MURPH Y
}

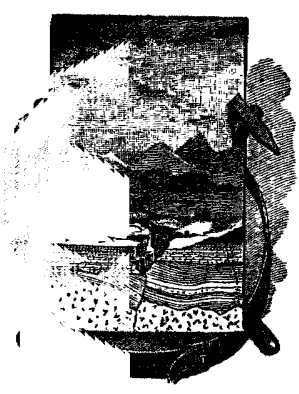

W ASHIN G T ON

GOVERNMENT PRINTING OFFICE 


\section{ONTENTS.}

Letter of transmittal

Introduction ....................

The Heppner, Oreg., flood ...

Character of stream and country $\ldots$

Sources of information . 10

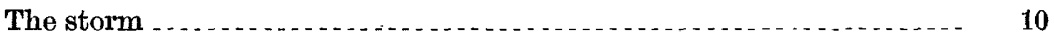

The flood $\ldots \ldots \ldots$

Effect of the flood

Lessons taught by tho flood $\ldots \ldots \ldots \ldots \ldots \ldots \ldots \ldots$

- The South Carolina flood. . . . .

Character of country and streams

The storm . . 13

The flood

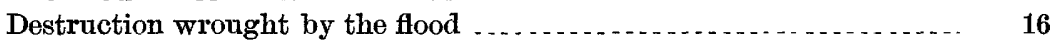

Lessons tanght by the flood ............... 18

Notes on early floods in the Mississippi Valley . $\ldots \ldots$

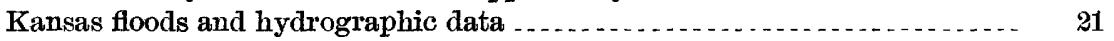

The flood of $1903 \ldots$

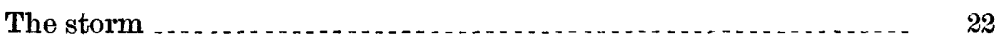

Duration, extent, and depth of rainfall ................... 22

Rainfall during storm and during May compared _........ 24

Character of watershed flooded .

Location, extent, and topography

Description of Kansas River....

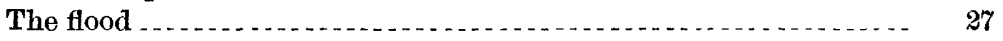

Reason for magnitude of flood .

Flood in vicinity of Topeka. ...

Flood in vicinity of Kansas City ............ 28

Flood in vicinity of Lawrence.

Flood in vicinity of St. Louis.

Destruction wrought by flood ............

By drowning or wetting ............ 30

By pressure and transportation

By scouring action

Hydrographic data of Kansas rivers . .

Method of obtaining data

Description of stations and discharge tables.

Kansas River at Lawrence and Lecompton, Kans . . . . . . $\quad 37$

Blue River near Manhattan, Kans...................... 43

Republican River at Junction, Kans................. 47

Republican River near Superior, Nebr................... 52

Republican River near Benkelman, Nebr ........ 55 
Kansas floods and hydrographic data-Continued.

Hydrographic data of Kansas rivers-Continued.

Page.

Description of stations and discharge tables-Continued.

Solomon River at Beloit and near Niles, I.ans. . . . . . . . . . . 56

Saline River at Beverly and near Salina, Kans . . . . . . . . 60

Smoky Hill River at Ellsworth, Kans.................. 65

Comparison of flood and ordinary data $\ldots \ldots \ldots$

Methods for preventing damage by future floods . . . . . . . . .

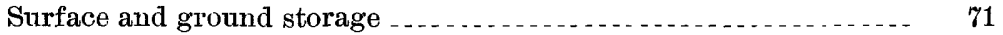

Effect of ground storage on flow of streams

Artificial storage .................... 73

Rapid removal of water

Cut-offs and overflow channels _.................... 75

Lummary 


\section{IL LUSTRA T I O N S.}

Plate I. $A$, View of the damaged portion of Pacolet mill No. 3; $B$, View of wreckage of Pacolet mills Nos. 2 and 3 .

Page.

II. Views of Pacolet: $A$, Before the flood; $B$, During the flood . . . . . .

III. Views of Clifton: $A$, Before the flood; $B$, After the flood ........

IV. Map of Kansas and adjacent States . . . . . . . . . . . . . . . . . .

V. A, View of "Flow-line" bridge as repaired with suspension span; $B$, View showing Missouri Pacific Railway bridge at Kansas City after the flood.

VI. Map of Kansas City showing flooded area ....................

VII. A, View of Twelfth street bridge, Argentine, Kans., after the flood; $B$, View of Kansas City Southern Railway bridge, Kansas City, after the flood

VIII. $A$, View showing bridge at Lawrence, Kans.; $B$, View showing bridge and gage at Lecompton, Kans

IX. A. View of Kansas River during flood, taken from the top of the National Bank, Lawrence, Kans.; $B$, View showing "Mad Waters " at Lawrence, Kans., during flood

$\mathrm{X}$. $A$, View showing an undermined section of the railroad near Lawrence, Kans.; $B$, View showing railroad track on top of coal car near Lawrence, Kans

XI. A, View of Bridge street, North Lawrence, Kans., during the flood; $B$, View of pile driver constructing temporary bridge over new north channel, Lawrence, Kans . . . . . . . . . . . . . . . . . . .

XII. A, Hydrograph of Kansas River at Lawrence and Lecompton, Kans.; $B$, Hydrograph of Blue River near Manhattan, Kans.; $C$, Hydrograph of Republican river at Junction, Kans ........ -

XIII. A, Hydrograph of Saline River near Salina, Kans.; $B$, Hydrograph of Solomon River at Niles, Kans.; $C$, Hydrograph of Smoky Hill River at Ellsworth, Kans

FIr. 1. Map showing distribution of Weather Bureau stations, etc . . . . . . .

2. Mean annual rainfall lines over Kansas. ......................... 


\title{
LETTER OF TRANSMITTAL.
}

\author{
DEPARTMENT OF THE INTERIOR, . \\ United States Geological SuRvey, \\ DIVISION OF HYDROGRAPHY, \\ Washington, D. C., January 9, 1904.
}

SIR: I have the honor to transmit herewith a manuseript prepared by E. C. Murphy, entitled "Destructive Floods in the United States in 1903," and request that it be published as a water-supply paper.

This paper treats of three of the destructive floods that occurred in the United States in 1903.

Very respectfully,

Hon. Charles D. Walcott, F. H. NEWELL, Hydrographer in Charge.

Director United States Geological Survey.

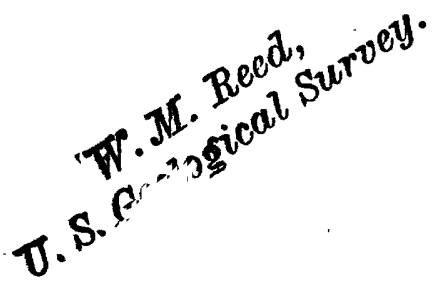




\title{
DESTRUCTIVE FLOODS IN THE UNITED STATES IN $1903 .{ }^{a}$
}

\author{
By E. C. Murphy.
}

\section{INTRODUCTION.}

Experience has shown that in the area of the United States great variations from normal elimatic conditions must be expected; the temperature, or the wind velocity, or the precipitation, or all three combined, may vary from the normal by a considerable amount at any place and in any season of the year.

The year 1903 will long be remembered for its extreme local variations from normal climatic conditions. A cloud-burst at Heppner, Oreg., on June 14, caused the loss of 200 lives and a quarter of a million dollars' worth of property; a tornado and an excessive rainfall at Gainesville, Ga., caused a loss of 100 lives and of property valued at half a million dollars; the excessive rainfall of June 6 in South Carolina devastated Pacolet, Clifton, and Glendale, causing the loss of many lives and of property valued at $\$ 3,000,000$, and tornadoes and excessive rainfall of the upper-central Mississippi Valley and lower Missouri Valley from May 16 to 30 resulted in the destruction of much property.

Nearly coincident in time with these extremes was the other extreme of small precipitation, with cold, backward spring, retarded growth of vegetation, forest fires, and very small flow of streams in New York and the New England States.

\section{THE HEPPNER, OREG., FLOOD.}

The flood of Willow Creek, Morrow County, Oreg., commonly spoken of as the "Heppner disaster," occurred on Sunday evening, June 14. It was due to one of those very heavy storms of short duration covering a very small area, so peculiar to the arid region, and popularly called a "cloud-burst." Such a storm is almost like the tornado in its suddenness, destructibility, and limited extent. The duration of this storm was only half an hour, and the resulting flood lasted

\footnotetext{
aThe writer desires herewith to express his thanks to Mr. F. H. Newell, hydrographer in charge, and Mr.J. C. Hoyt, computer, for valuable suggestions and assistance in the preparation of this paper, and to Messrs. J. T. Whistler, B. S. Drane, and W. G. Russell for their reports on the floods in their respective districts.
} 
less than one hour, yet in that short time one-third of the town of Heppner was entirely swept away, one-quarter of a million dollars' worth of property destroyed, and over 200 persons, from a total population of 1,400 , were drowned.

Character of stream and country.-Willow Creek rises in the southeastern part of Morrow County in the west spur of the Blue Mountains, and flows northwest into Columbia River. The distance in a straight line from its source to its mouth is about 100 miles. Its three principal tributaries are Balm Creek, which enters a short distance above Heppner; Hinton Creek, which enters a short distance below Heppner; and Wilson Creek, the mouth of which is about 25 miles below Heppner. At its mouth Willow Creek has an elevation of about 220 feet, and at Heppner, 45 miles by rail above its mouth, it is 1,920 feet above sea level. The mean slope is, therefore, 37.8 feet per mile. The channel at Heppner has a width of 30 to 40 feet, and the banks are from 10 to 15 feet in height. The valley is a fertile strip of cultivated land, 500 to 1,500 feet in width. Back from the valley the country on both sides has barren rocky soil, with steep slopes, and the precipitation passes off very rapidly.

Sources of information.-Unfortunately there were no measurements of rainfall and gage heights in the watershed of Willow Creek, and the extent of the storm and the volume of run-off can not be determined. All the data on which are based the estimates of run-off, duration of storm, and height and duration of flood were obtained from persons who saw the flood at various points along Willow Creek.

On the fourth day after the flood Mr. John T. Whistler, engineer of the United States Geological Survey, visited Heppner and made a thorough study of the situation. From his description, published in Engineering News of July 16, and from additional facts obtained from personal conversation with him, this report has been prepared.

The storm.-The storm came on suddenly between 4 and 5 p. m., and had entirely passed -away in less than half an hour. Authentic accounts agree that it started in the foothills of the Blue Mountains, on Balm Creek, about 8 or 10 miles north of Heppner, and moved north, down Balm Creek, to some distance beyond Willow Creek. It is estimated that the storm area was from 2 to 4 miles in width and from 8 to 10 miles in length and affected an area of perhaps 20 square miles.

The storm was accompanied by a very heavy fall of hail, the depth of which can not definitely be ascertained, but an idea of its amount can be formed from the fact that five days after the storm some bodies were found in drifts of hail in a nearly perfect state of preservation. Some of the hailstones are said to have measn red $1 \frac{1}{4}$ inches in diameter. Five days after the storm some that measured five-eighths of an inch by seven-sixteenths of an inch were removed from a house buried under silt and brush. Nearly all of this hail was of clear ice; 
unlike the usual hailstones, which are more or less opaque and built up from a nucleus by successive layers.

The flood.-The height of the flood may easily be determined from the high-water marks, though these are often deceiving to the unpracticed eye, as marks are frequently found in places where the water did not reach. Bark is knocked off trees by floating bodies that project a considerable distance out of the water; small trees are often bent over and light drift deposited on them, and when the water pressure is removed and the tree straightens up this material is lifted high above the water level. But the rings of silt left on trees, all at approximately the same level, show the true water line. These watermarks show that the flood plane at Heppner was about 5 feet above the general road level and had a width of about 500 feet. The maximum depth of the flood at the center of the creek was from 15 to 20 feet.

The crest of the flood wave is said to have been almost simultaneous with the first water as far down the creek as Lexington; so that if a person had been standing on a structure 40 feet in height above the center of the creek bed at Heppner he would have seen flowing down the creek a bank of water 20 to 25 feet in height and having a face slope of about $30^{\circ}$ with the horizontal. The force of a bank of water of this height moving down a slope of 38 feet to the mile, sweeping everything before it, can readily be imagined. At Ione, 8 miles below Lexington, the crest of flood was one-half hour behind first water, and at Cecils, 14 miles above the month, it was several hours behind.

At Heppner the creek is said to have returned to its normal flow in one and one-half hours after the passage of the crest of the flood. The crest is said to have reached the mouth of the creek about twenty hours after passing Heppner, the speed of erest thus averaging from 5 to 6 miles an hour.

The discharge on Balm Creek near its mouth was computed from the formula:

$$
v=C \sqrt{s r}
$$

$s$ being the slope, $r$ the hydraulic depth, $C$ a coefficient, and $v$ the mean velocity.

Two sections 2,200 feet apart gave a slope of 0.025 ; area, 1,700 square feet; wet perimeter, 260 feet. With these data and the value of 0.040 for the coefficient of roughness, the maximum discharge is found to be 36,000 second-feet. As the flood lasted less than one hour, the total flood volume was probably not more than the maximum flow for one-third of an hour. On this assumption the total volume of the flood at this point amounted to about 1,000 acre-feet.

The discharge of Willow Creek at Heppner and at Lexington has been computed. In these computations the mean velocity was assumed to be 6 miles per hour at Heppner and 4 miles per hour at Lexington. The total volume of flow was also assumed to be the maximum flow 
for one-third of the time. The total flood volume at Heppner was found to be 1,100 acre-feet, and at Lexington 800 acre-feet.

The increased discharge at Heppner over that in Balm Creek was due principally to the water which enters Willow Creek below the mouth of Balm Creek, but partly to a small amount from shore. The flood volume near the mouth of Willow Creek was also computed and found to be 750 acre-feet.

It is very likely that the storm area was at least 20 square miles. Assuming that two-thirds of the rainfall reached Heppner, the total precipitation was approximately 1,600 acre-feet, which amounts to $1 \frac{1}{2}$ inches in depth over this area, a rate of rainfall of about 3 inches per hour.

The flood water was very heavily laden with silt and in color is said to have resembled molasses.

Effect of the flood.-As a result of the flood one-third of the town of Heppner was entirely destroyed, and about 200 lives were lost. It seems almost incredible that a flood of a depth of only 5 feet above the general road level of the town should cause such a loss of life. The explanation lies in the peculiar construction of the houses. Nearly all of the houses simply rested on posts or open foundations of stone. The water freely passed underneath, but could not so rapidly get to the inside of the houses, so they were lifted off their foundations and floated away like boats. The rapid velocity soon drove them against trees or other objects and erushed them to pieces. In such a swift current and among such masses of timber it was almost impossible for a person to get ashore.

The duration of the flood was so short that the only considerable scouring effect observed was at the mouth of Balm Creek, where the flood crossed Willow Creek and struck the opposite shore. At this point a new channel was formed.

In 1888 a similar flood, possibly a larger one, came down Hinton Creek, but did little damage, as there were only a few houses there at that time. In 1883 there was a large flood in Willow Creek, but reliable records are not available for the comparison of these floods with the one of 1903.

Lessons taught by the flood.-Storms of great violence, short duration, and affecting comparatively small areas are to be expected occasionally in all parts of the arid and semiarid region, as the bare, steep, nonabsorbent surface causes the resulting floods to be large, sudden, and very destructive. All streams should have an ample waterway under bridges and through towns, and all buildings should be out of reach of the flood. No building that can be lifted from its foundation and swept away should be allowed in the area of a possible flood. Buildings in the line of a flood, such as mills, warehouses, pumping stations, etc., should be protected from drift during high water. 


\section{THE SOUTH CAROLINA FLOOD. $a$}

A destructive flood occurred in Spartanburg County, S. C., on June 6,1903 . Considering the small area affected by the storm, the precipitation was very large and the loss of life and property great.

Character of country and streams. - In the twenty-fonr hours of the storm there was a rainfall of from $3 \frac{1}{2}$ to 5 inches in the counties of Cherokee, Spartanburg, Greenville, and the eastern half of Pickens, in South Carolina; and in the southern part of Rutherford, Polk, and Henderson counties, in North Carolina-a total area of 2,300 to 2,500 square miles. This region is situated on the southern slope of the Saluda Mountains. It does not extend up into the mountains, but includes the foothills and rolling country. About half of it is covered with timber; the remainder is cultivated and pasture land. The surface slopes are such that the water runs off rapidly and there is very little storage.

The streams that drain this area are Pacolet, North, South, and Middle Tiger, and Enoree rivers. These are tributaries of Broad River and enter it from the west. The upper tributaries of Saluda River, which flow to the west, rose to an unusual height, but little damage was done on them. Practically all the damage was confined to Spartanburg County, S. C.

The streams mentioned rise within a comparatively short distance of each other. North Fork of the Pacolet heads in Polk County, N. C.; all the others head in Greenville County, S. C. They are characterized by deep, narrow channels, with rapid fall. The Pacolet is said to have a fall of 500 feet from its head to Pacolet mills, a distance of 35 miles. There are no ponds or wide bottom lands to hold back the water in time of flood. The ground was soaked almost to saturation just previous to the flood, so that there was very little ground storage.

The storm.-During the week preceding this flood there was rain over this area almost daily; not hard rains, but gentle, penetrating showers, that nearly saturated the soil. On Friday, June 5 , 1903, rains fell almost incessantly. 'In the evening the rain became more violent and continued until $4 \mathrm{a}$. m. without interruption. 
The precipitation for the first six days of June, as reported to the United States Weather Bureau, is given in the following table:

Daily rainfall reported from Weather Bureau stations in and surrounding area of South Carolina flood for the first six days in June, 1903.

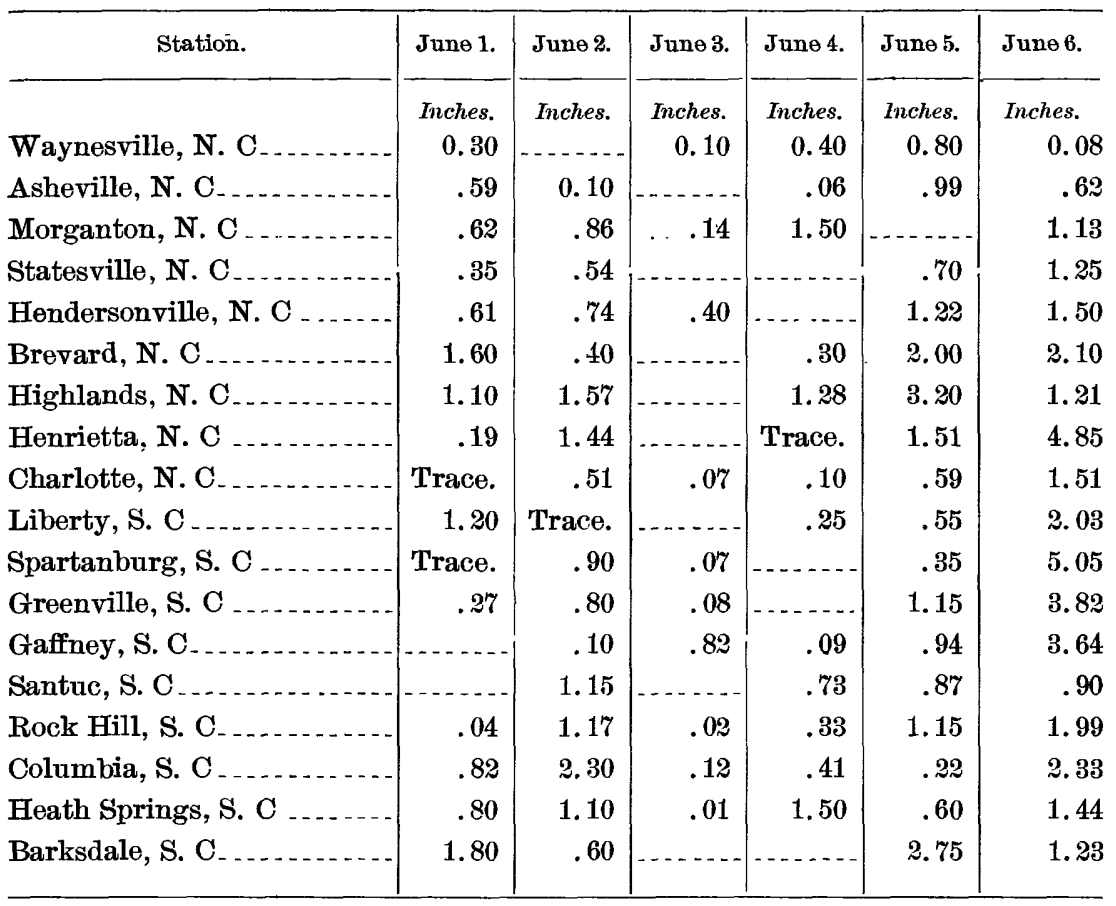

Fig. 1 shows the location of some of these stations and the depth of rainfall reported at each on the morning of June 6, 1903. It is seen that the greatest precipitation in the twenty-four hours was at Spartanburg, diminishing in amount in every direction from that place, rapidly to the northwest and southeast and gradually to the northeast and southwest.

The precipitation northwest of Spartanburg was considerably. greater than 5 inches. The washouts, landslides, and gullies cut by the flowing water indicate that the precipitation over the rain area was probably from 7 to 11 inches in the twenty-four hours preceding the morning of June 6, 1903. This region is included in an area that Prof. A. J. Henry, of the United States Weather Bureau, states is second in precipitation in the United States. The people who live in that region are accustomed to very heavy rains; and their estimates confirm the figures given above of the precipitation. 
U. S. GEOLOGICAL SURVEY

WATER-SUPPLY PAPER NO. 96 PL I

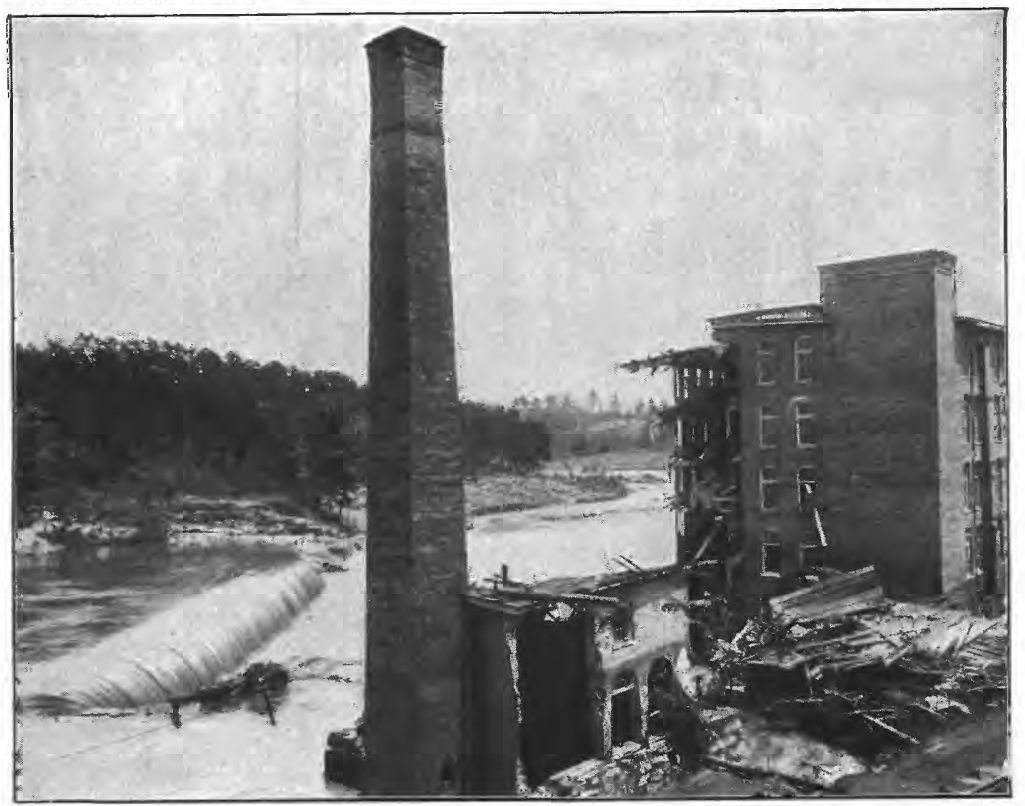

A. VIEW OF DAMAGED PORTION OF PACOLET MILL, NO. 3.

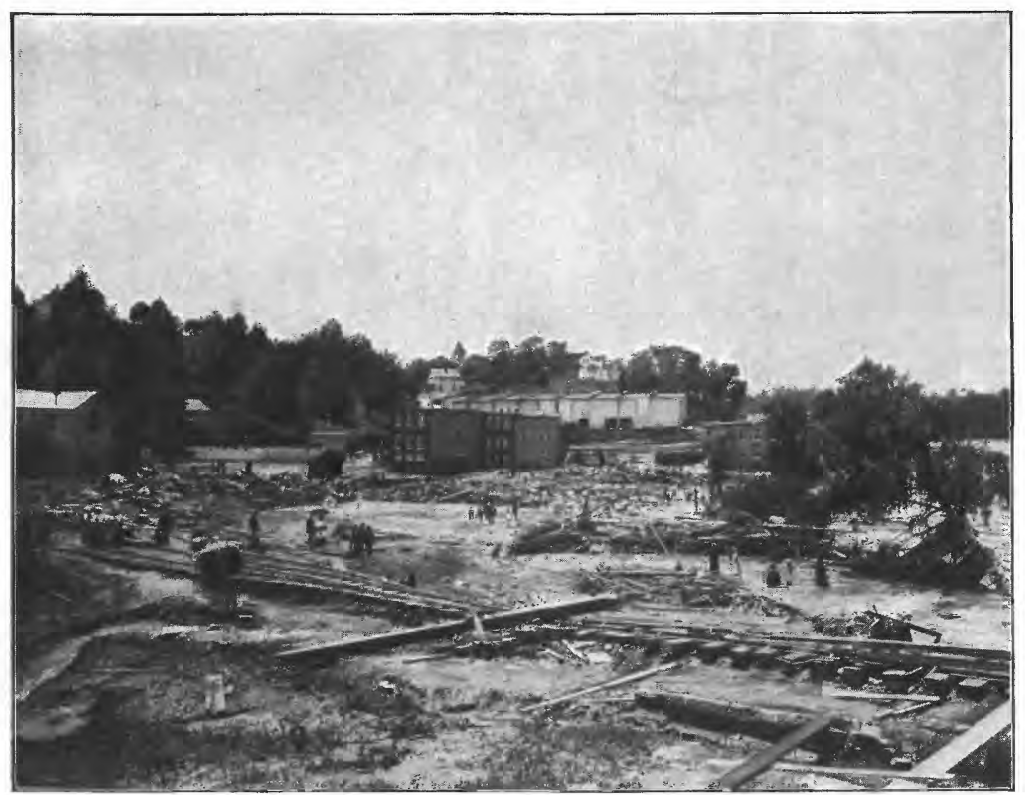

B. VIEW OF WRECKAGE OF PACOLET MILLS, NOS. 2 AND 3. 
The flood.-There are no gaging stations on the streams on which the damage was done by this flood. For about seven years the United States Geological Survey has maintained gaging stations on Broad

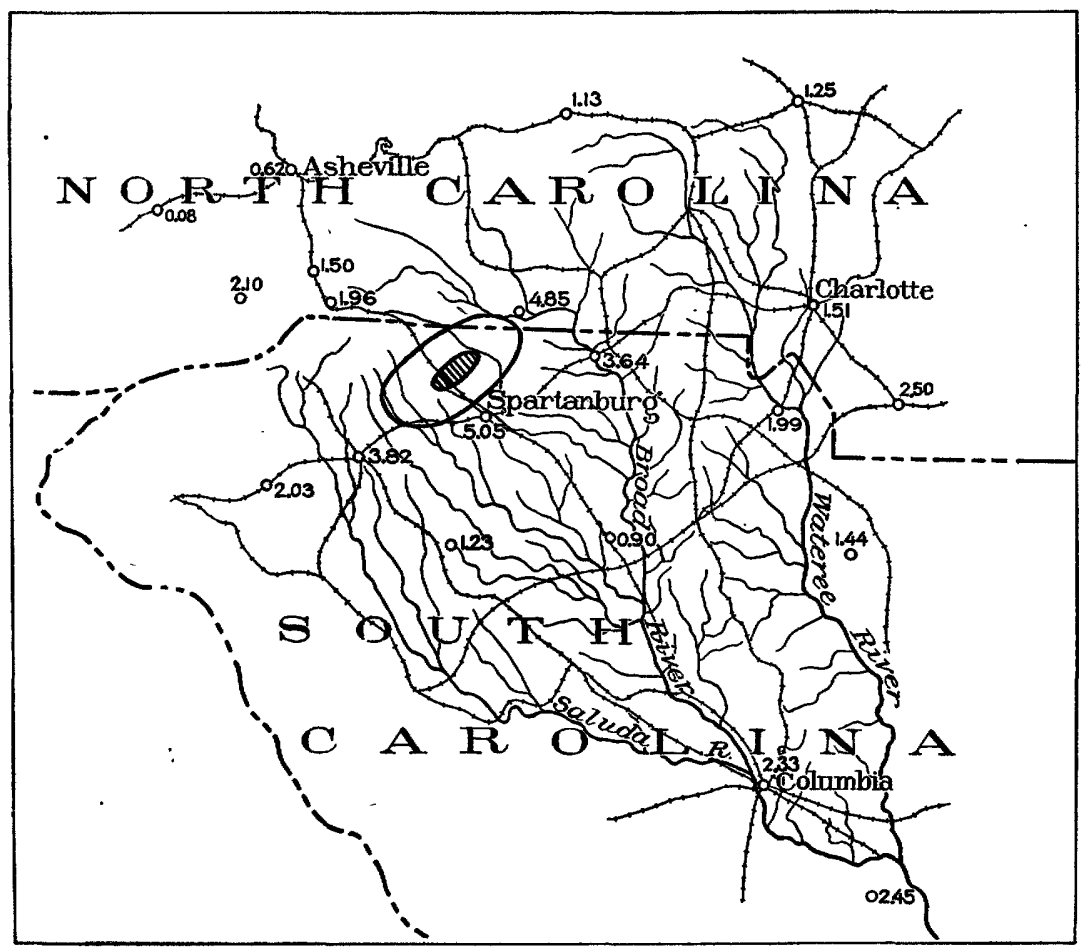

FIa. 1.-Map showing distribution of Weather Bureau stations, etc.

River at Alston, about 75 miles below Pacolet, and on the Saluda near Waterloo. The mean daily gage heights at each of these places from June 1 to 10 are given in the following table:

Mean daily gage heights, in feet, June 1 to 10, 1908.

\begin{tabular}{|c|c|c|c|c|c|c|c|c|c|c|}
\hline Place. & 1. & 2. & 3. & 4. & 5. & 6. & 7. & 8. & 9. & 10. \\
\hline Broad River at Alston, S. C . . & 5.60 & 7.55 & 8.70 & 6.65 & 7.30 & 13.60 & 27.20 & 26.70 & 17.30 & \\
\hline Saluda River at Waterloo, S. C & 9.85 & 10.40 & 8.40 & 7.75 & 12.15 & 14 & 19.25 & 22.35 & 14.45 & 10.30 \\
\hline
\end{tabular}

The highest water previous to this flood at these stations during these seven years was in 1901. At Alston, S. C., the maximnm on June 7, 1903, was 29 feet, which is $5 \frac{1}{2}$ feet higher than in 1901. At Waterloo the maximum was 23.15 feet, which is $2 \frac{1}{4}$ feet higher than in 1901.

These figures, while they convey some idea of the magnitude of this flood, are not definite, becanse these stations are far below where the 
storm occurred and where the damage was done. Had there been a gaging station on Pacolet River near its mouth it would have shown a much greater difference between the flood readings of 1901 and 1903 than do the figures at the Alston station.

A few flood marks of the flood of 1852 still remain at points on these streams. At Fingerville the new mark is 3.7 feet higher than the old one. At Whitneys mill, on Lawsons Fork near Spartanburg, the new mark is 9.9 feet higher than the old one. On the main Pacolet and Middle Tiger rivers the new marks are about 10 feet higher than the old ones. On Enoree River the new mark is $1 \frac{1}{2}$ feet lower than the one of 1852 .

For computing the discharge a section was taken above the dam at Pacolet. The pond at this point is shallow and the section rather narrow, and it is therefore believed that the current was fairly uniform. On the right bank the high-water mark was found in a garden, and is undoubtedly reliable. This gives a difference in elevation between high and low water of 24.4 feet and a flood section of 6,150 square feet. At gaging stations during floods, when the section was similar and the slope similar or not so great, the mean velocity has been observed to be as much as 5.78 feet per second. Assuming this velocity and using the area of section given above, the discharge at this place is $35,5+7$ second-feet. 'The drainage area of the Pacolet at this place is about 400 square miles. The estimated discharge is equivalent to a run-ofi of 88.9 second-feet per square mile.

The flood of Catawba River of May, 1901, which caused great destruction of farming land, had an estimated run-off per square mile of 51.8 second-feet at the Catawba, N. C., station, and of 44.4 secondfeet at the Rockhill, S. C., station. The estimated run-off at Pacolet during the 1903 flood is seen to exceed that of 1901 at the Catawba by 70 per cent and at Rockhill by 100 per cent. It is possible, however, that the estimated run-off at Pacolet is too great. The method of obtaining the mean velocity was not very reliable.

Destruction vorought by the flood.-There was some destruction of property on Tiger River, but the largest amount was on Pacolet River, at Clifton mills and Pacolet mills. The destruction of the Clifton mills is thus described in the report of Mr. B. S. Drane:

Clifton mill No. 3, known as " Converse mill," stood just above the bridge over which the main line of the Sonthern Railway crosses Pacolet River. It was built in 1890 and 1895 , and as completed was a four-story mill 496 feet long and 100 feet wide. It was valued at $\$ 1,000,000$ and contained 50,100 spindles.

The river was noticed to be about 8 feet above low water at midnight, but did not appear to be rising, and caused no anxiety. At 3.30 a. m. Mr. Kirby, master machinist of the mill, upon going down, saw that the water was beginning to rise into the wheelhouse. Getting assistance, he began to remove belts and ropes, but before any headway had been made the water forced him to leave. By 4.30 the rise was beginning to be rapil, and in a few minutes the water was flowing over the right end of the dam and breaking on the boiler houses and shops. These were wrecked before 5 o'clock. A little after 5 the brick stack, 137 feet high, was washed down with the part of the dam immediately behind it; it fell 


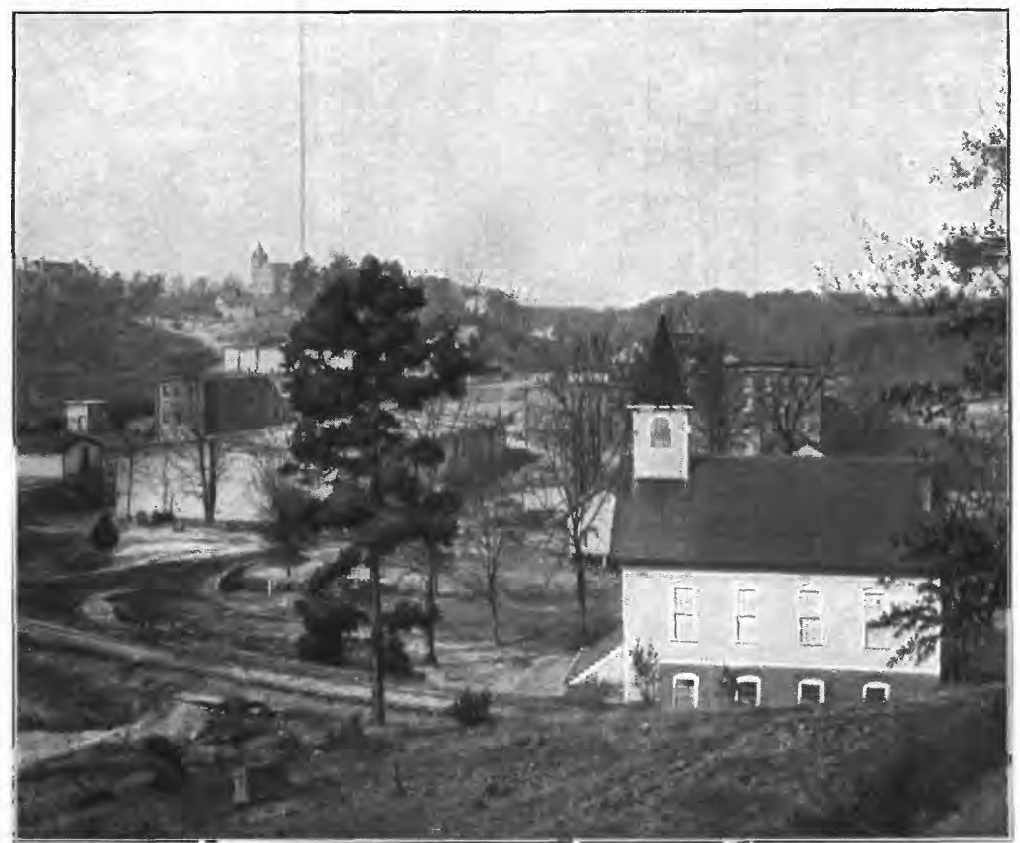

A. PACOLET BEFURE THE FLOOD OF 1903.

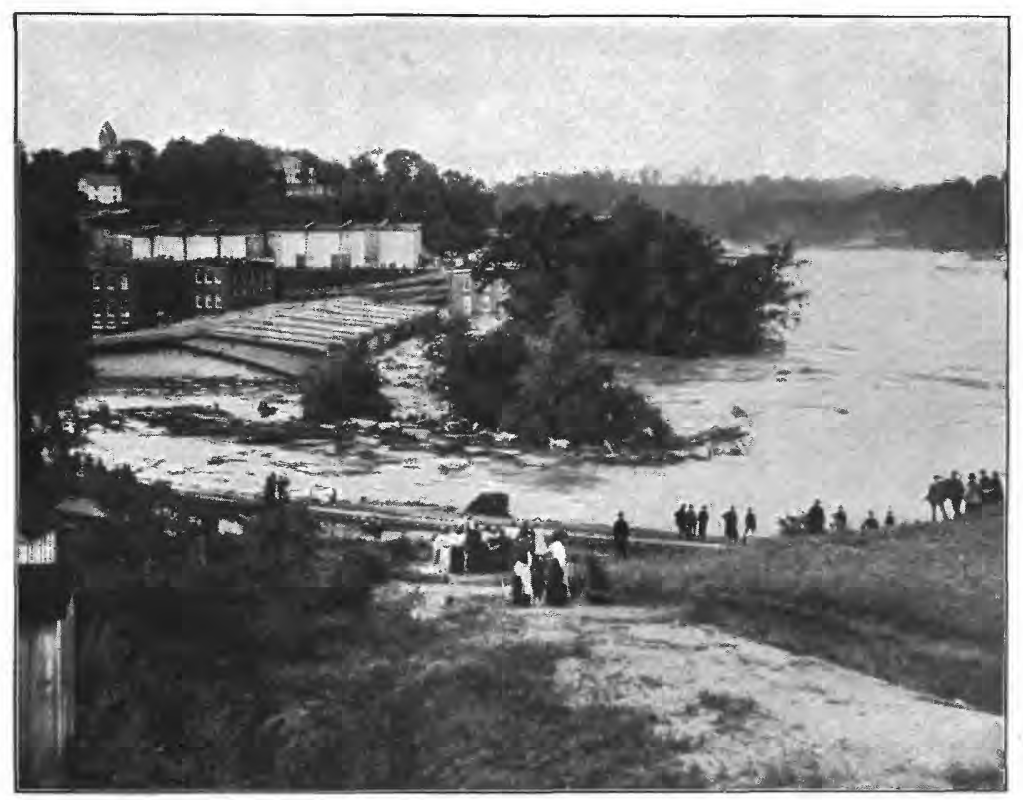

B. PACOLET DURING THE FLOOD OF 1903. 
on the corner of the mill. The mill began to wash down immediately, and the wreck was practically complete by $60^{\circ}$ clock. The mill was washed entirely away, except for the three-story picker room. Shops, boiler houses, wheelhouse, and 16 cottages were also carried away.

The dam here had a section of 27 feet height, $2 r$ feet base. and 11 feet crest. The construction was said to have been hasty and of materials much inferior to those usual on this riter. The crest was broken off irregularly to a depth averaging 10 feet for 100 feet from the right bank, and to a depth of $r$ feet for the next 40 feet. One footbridge and one county bridge, of wood, were carried away from just below the mill.

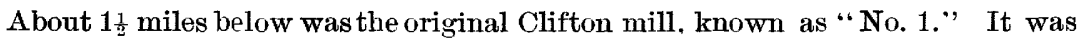
built in 1880 , and had 27,500 spindles. At this point the rise was not alarming at $2 o^{\prime}$ clock a. $\mathrm{m}$. The rapid rise began at some time between half 1 ast 4 and 5 . Just after 5 the water rose 2 feet in ten minutes. according to the assistant superintendent. The first thing to be carried away was a large hall. This floated off at about 5.45 and was hurled down into the upper corner of the mill, which stood out into the stream. The blow broke in part of the corner of the mill, but the destruction of the mill did not begin until the wreckage from above began to come down thickly, a little after 6 o'clock. Large timber's were then dashed into the projecting corner and the mill began to settle down gradnally, little by little, beginning at this end. Altogether about 110 feet of the main building and the wheelhouse were totally wrecked. The machinery on the two lower floors was severely damaged throughont the length of the mill by the water, mud, and drift. The dam was uninjured, except for the tearing off of the wooden apron. Fifteen cottages were carried away from this mill village. About 8 o'clock the water began very slowly to fall.

Clifton mill No. 2. known as " Dexter mill," was a little over a mile from Clifton, was built in 1888 , and had 30,500 spindles.

This mill stood on a point on the left bank. Just opposite the mill the right bank is steep and high, while on the left bank a ridge extends out on the point almost to the mill. Above the mill, on either side of the river, the hills open out, and there the greater part of the mill village stood. 'Also on the point on the left bank below the mill were many cottages.

The rise here began to alarm the watchman at $3 \mathrm{a} . \mathrm{m}$., and at 3.30 it began to be rapid. One of the watchmen noticed that the rise was 1 font in five minutes at about 4 o'clock. The alarm was sent out among the operatives at once. Most of them refused to realize that they were in any danger and would not make any effort to save themselves and their property until the water surrounded them. There were many narrow escapes, but at least 52 persons were lost here, most of them women and children. There was a deep deposit of sand and silt over the point below the mill where most of the lives were lost. Toward the end of the week following the disaster this began to crack as it dried. Searching parties kept watch of these cracks, and wherever flies were seen to crawl down them they dug. Several human bodies were found in this way.

At about twenty. minutes past 4 the covered wooden highway bridge was washed down. The cotton warehouses and some of the cottages began to go about 6 o'clock, but the mill stood until $\%$. At that time the wreckage was coming down thickly from the upper mills. Exactly as at the Clifton mill above, the onter upstream corner was torn down. This mill was L-shaped, a wing extending shoreward from the lower end. When the mill was surrounded by the flood the heavy wreckage from above was hurled into this extension, tearing down the middle of it and practically filling the whole with driftwood. The machinery throughout the two lower floors of this mill was largely destroyed by the sand and drift thrown into it. All the cotton and cloth warehouses here were washed IRR $96-04 \longrightarrow 2$ 
away; 42 of the company's cottages and 6 belonging to outsiders were wrecked and carried away.

After bending to the left about the point on which the mill stands the river formerly bent to the right again around a low point on the right bank: During this flood the water overflowed this low point and cut a new channel over it, abandoning the old one. The crescent-shaped island left is about 400 yards long and 100 wide.

Several lines of the Southern Railway were tied up for about a week. The main line from Charlotte, N. C., to Atlanta, Ga., passing through Spartanburg, was broken by the washing away of a bridge over Lawsons Fork of Pacolet River. The Charleston and Western Carolina Railway, also entering Spartanburg, lost its bridge over Tiger River.

What purports to be a very conservative estimate of the financial loss due to the freshet is given as follows:

Estimate of losses caused by South Carolina flood.

Clifton mills, Nos. 1, 2, and 3 $\$ 1,750,000$

Pacolet mills, Nos. 1, 2, and 3 $1,250,000$

Glendale mills 30,000

Mary Louise mills 18,000

Whitney mills 5,000

Fingerville mills

Tucapau mills 10,000

Tiger mills 8,000

Two other mills. 20,000

Bridges 15,000

Spartanburg Electric Railway Company

Southern Railway Company

300,000

Not included above (lands and crops ruined, etc.), at least 6,000

Total

$3,450,000$

These figures do not include the loss due to the interruption of railway traffic, the stoppage of large industries throwing thousands of operatives out of employment, the loss to the various trades and commercial enterprises, and, worst of all, the loss of over 50 lives.

Lessons taught by the flood.-Very heavy storms, covering small or large areas, are to be expected on the southern and eastern slopes of the Appalachian Mountains. Floods much greater and more destructive than ordinary result from these storms.

Ample unobstructed waterway must be provided for streams through towns. Usually the greater part of the destruction wrought is due to the failure of a temporary dam formed by drift in front of a bridge. Drift of all kinds collecting in front of a bridge forms a dam, raises the water several feet higher than it would have been without the obstruction, finally the pressure on the obstruction becomes so great that it is swept away, and the resulting wave destroys other bridges and buildings that otherwise would nothave been injured. The washing out of a dam by the water cutting a channel around one end of it 


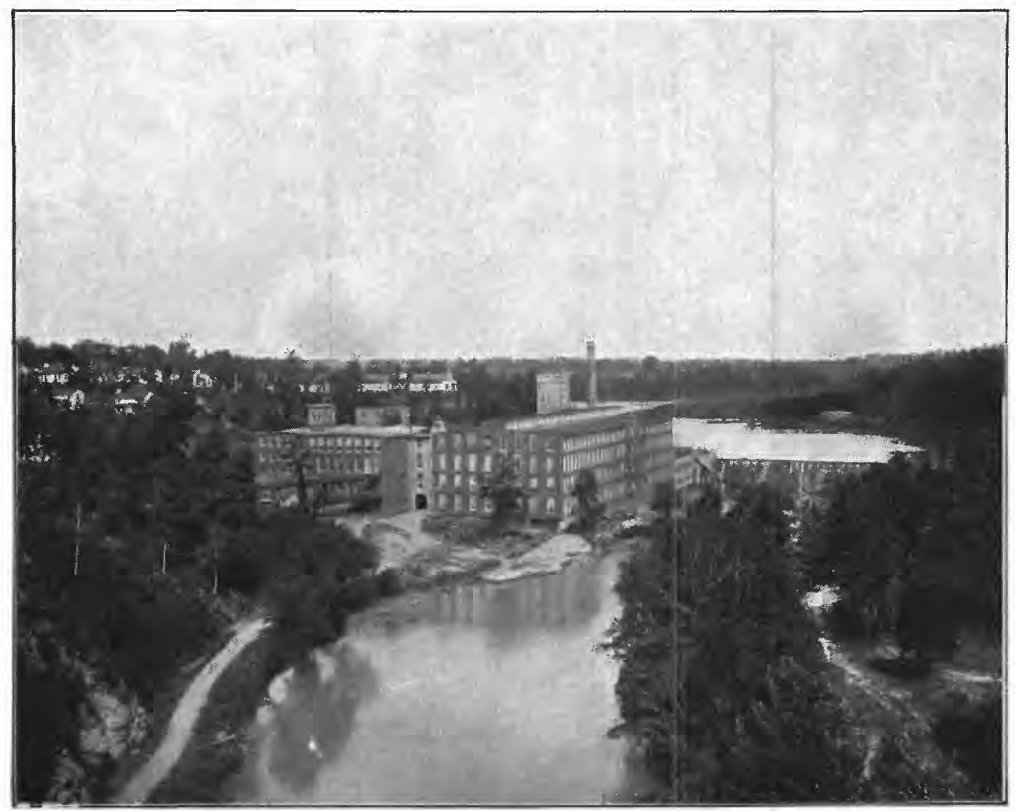

A. CLIFTON BEFORE THE FLOOD OF 1903.

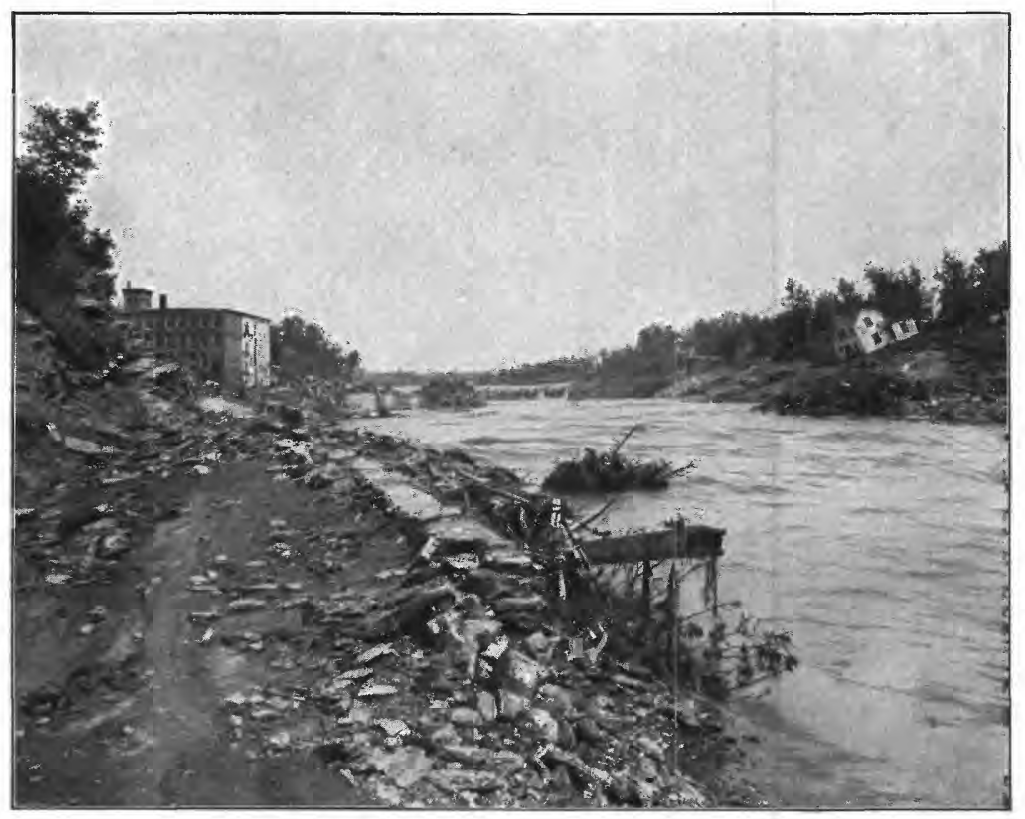

B. CLIFTON AFTER THE FLOOD OF 1903. 
is often the canse of a great wave that sweeps away bridges and buildings below that otherwise would not have been injured.

Buildings that can be lifted from their foundations and swept away should not be allowed in the path of a possible flood.

Mills, power stations, and other buildings on the banks of streams should be protected from the destructive action of drift during high water.

\section{NOTES ON FARLY FLOODS IN MISSISSIPPI VALLEY.}

Data on the floods of the Mississippi River basin prior to 1798 are very meager. Since that date a record of the fluctuation of the surface has been kept at one or more points along the river. At Natchez a record was kept by Governor Winthrop Sargeant from 1798 to 1819 , by Samuel Davis from 1819 to 1841, and by Professor Forshey from $18+1$ to 1848 . From 1848 to 1851 a record was kept at Carrollton by Professor Forshey. From 1851 to 1860 a very comprehensive study of the lower basin was made by Humphrey and Abbott. From 1851 to the present time several gaging stations have been maintained by the United States engineers, and for several years the United States Weather Bureau has also measured surface fluctuations at several places in this basin. From the available data the following tables have been prepared.

The following table, ${ }^{a}$ from the records of Dr. George Englemann, shows the date of each flood on the Mississippi River at St. Louis from 1785 to 1865 and the height of the highest water above a datum plane:

Statistics of floods at St. Louis, Mo., 1755 to 1865.

\begin{tabular}{|c|c|c|c|}
\hline Date. & $\begin{array}{c}\text { High } \\
\text { water. }\end{array}$ & Date. & $\begin{array}{c}\text { High } \\
\text { water. }\end{array}$ \\
\hline April, 1785 & $\begin{array}{l}\text { Feet. } \\
42.0\end{array}$ & May 20,1852 & $\begin{array}{l}\text { Feet. } \\
\quad 28.0\end{array}$ \\
\hline March, $1828 \ldots$ & 33.6 & May 7, $1853 \ldots$ & 30.0 \\
\hline May 8,1833 & 27.0 & May 9,1856 & 27.4 \\
\hline May 28,1838 & 27.4 & June $14,1858 \ldots$ & 37.0 \\
\hline May 2,1843 & $2 \pi .2$ & May $15,1861 \ldots$ & 25.3 \\
\hline June 27,1844 & 41.0 & April 26, 1862 & 31.3 \\
\hline June $27,1845 \ldots$ & 32.4 & May $4,1863 \ldots$ & 18.0 \\
\hline May 10,1846 & 25.0 & May $14,1864 \ldots$ & 24.3 \\
\hline March 10, 1849 & $2 \pi .4$ & July $28,1865 \ldots$ & 26.7 \\
\hline June 10, 1851 . & $2 \% .0$ & & \\
\hline
\end{tabular}

According to these records the highest water at St. Louis, Mo., was in April, 1785, when the gage read 1 foot higher than in 1844 and 4 feet higher than in June, 1903. Very little is known of the flood of

$\alpha$ Russell, T. Stages of Mississippı River and its principal trubutaries. U. S. Weather Bureau, Washington, D. C., 1891. 
1785. The 1844 flood is well remembered by persons still living in this section of the country: In 1858 high water at St. Louis came within 4 feet of that of 1844 , and the flood of 1845 was within about 9 feet of that of 1844. The following table gives the dates of highest water on the Mississippi at St. Louis, Mo., and on the Missouri at Kansas City, Mo., for each year from 1872 to 1903 ; also the gage reading:

Statisties of floods at St. Louis, Mo., and Kansas City, Mo.

\begin{tabular}{|c|c|c|c|c|}
\hline \multirow{2}{*}{ Year. } & \multicolumn{2}{|l|}{ St. Louis, Mo. } & \multicolumn{2}{|l|}{ Kansas City, Mo. } \\
\hline & Date. & $\begin{array}{c}\text { Gage } \\
\text { height. }\end{array}$ & Date. & $\begin{array}{c}\text { Gage } \\
\text { height. }\end{array}$ \\
\hline $18 \% 2$ & June 12-14 & $\begin{array}{l}\text { Feet. } \\
23 . \%\end{array}$ & & Feet. \\
\hline 1873 & April 11... & 26.7 & July $5 \ldots \ldots$ & 19.3 \\
\hline 1874 & June 19-20 .. & 19.1 & June $17-19$ & 16.2 \\
\hline 1875 & August $3 \ldots$ & 30.5 & April $30 \ldots$ & 17.8 \\
\hline 1876 & May $10_{\ldots} \ldots$ & 33.7 & June $16 \ldots$ & 18.0 \\
\hline $18 \% 7$ & June $14 \ldots$ & 25.3 & June $10 \ldots$ & 22.2 \\
\hline 1878 & June $15 \ldots$ & 26.5 & July $3 \ldots \ldots$ & 19.8 \\
\hline 1879 & July $3 . \ldots$. & 21.9 & June $30 \ldots$ & 19.2 \\
\hline 1880 & July $2 \ldots \ldots$ & 26.2 & July 10-12 . . & 16.7 \\
\hline 1881 & May $6 \ldots$ & 34.3 & April $30 \ldots$ & 26.3 \\
\hline 1882 & July $5 \ldots$ & 33.1 & July $3 \ldots$ & 19.2 \\
\hline $1883 a$ & June $26 \ldots$ & 35.5 & June $26 \ldots$ & 23.8 \\
\hline 1884 & April 9-10 & 28.8 & $\ldots$ & $\cdots$ \\
\hline 1885 & June $17 \ldots$ & 27.8 & June $19 \ldots$ & 19.1 \\
\hline 1886 & May $13 \ldots$ & 27.7 & April 1i.... & 15.8 \\
\hline 1887 & April $3 \ldots$ & 21.4 & July $3 \ldots$ & 18.9 \\
\hline 1888 & June $4 \ldots .$. & 30.1 & 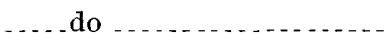 & 20.4 \\
\hline 1889 & June $1 \ldots \ldots$ & 25.3 & August 14_... & 13.9 \\
\hline 1890 & - _ do ......... & 21.3 & June $11 \ldots \ldots$ & 17.2 \\
\hline 1891 & July $4 \ldots \ldots$ & 24.4 & July $1 \ldots \ldots$ & 23.1 \\
\hline 1892 & May $19 \ldots \ldots$ & $36 . \tau$ & May $21 \ldots$ & 24.9 \\
\hline $1893^{-}$ & May $3 \ldots . .$. & 32.3 & April $13 \ldots$ & $17 . \tau$ \\
\hline 1894 & May $11 \ldots$ & 24.1 & June $21 \ldots$ & 20.1 \\
\hline 1895 & July $8 \ldots \ldots$ & 17.8 & June $12 \ldots .$. & 16.9 \\
\hline 1896 & May $26-28 \ldots \ldots$ & 28.4 & May $22 \ldots$ & 19.2 \\
\hline 1897 & May $2 \ldots \ldots \ldots$ & 31.7 & April $20 \ldots$ & 22.6 \\
\hline 1898 & May $23 \ldots \ldots \ldots$ & $2 \pi .2$ & June 12 .... & 21.5 \\
\hline 1899 & April $27 \ldots \ldots \ldots$ & 25.6 & July $9 \ldots \ldots$ & 22.2 \\
\hline 1900 & March 16 & 23.4 & June $20 \ldots$ & 17.8 \\
\hline 1901 & April $18-19 \ldots \ldots$ & 22.4 & June $24-25 \ldots$ & 19.4 \\
\hline 1902 & July $26 \ldots \ldots \ldots$ & 26.9 & July $15 \ldots \ldots$ & 23.2 \\
\hline 1903 & June $10 \ldots \ldots$ & 38.0 & June $1 \ldots \ldots$ & 35.0 \\
\hline
\end{tabular}


It is seen that at no time during the fifty-nine years from 1844 to 1903 has the highest water been within 3 feet of the stage it reached on June 27, 1844. Seven times, however, it approached within about 8 feet of it. The records of the Kansas City station on Missouri River cover a period of thirty years; the flood of 1903 exceeded in height by about 9 feet that of any year during this period; only nine times in the thirty years was the highest water at this place within 15 feet of its height in 1903.

The years of greatest flood at St. Louis are usually years of greatest flood in the lower basin of Mississippi River, but this is not always the case. Very frequently the lower Mississippi is very high while at St. Louis the stage is considerably below that of the great flood. This is due to a large part of the discharge of the lower basin coming from Ohio and Arkansas rivers, which enter the Mississippi below St. Louis. The frequency of floods and their magnitude increases with the distance down the river. Floods are the exception at Kansas City; they are the rule below Memphis.

\section{KANSAS FLOODS AND HYDROGRAPHIC DATA.}

\section{THE FLOOD OF 1903.}

The Kansas flood of 1903 is, with the exception of the flood of 1844 , the largest one on record in the upper-central Mississippi and lower Missouri river valleys. In loss of property and life the flood of 1903 was vastly more destructive than that of 1844 , on account of the country now being much more thickly settled and improved. Although the loss of.property in the aggregate is large-estimated at $\$ 22,000,000$ in Kansas and Kansas City, Mo., alone-it is not large when one considers the great value of the property in the path of the flood. The loss of life is surprisingly small considering the population driven from their homes and the rapirl approach and vastness of the flood. The following table (p. 22) gives flood data of Kansas River taken at Lawrence and Lecompton. 
Flood data, Kansas River, 1881 to 1903.

\begin{tabular}{|c|c|c|c|c|}
\hline Year. & Place. & Date. & $\begin{array}{l}\text { Gage } \\
\text { reading. }\end{array}$ & Discharge. \\
\hline & & & Feet. & Sec. ft. \\
\hline 1881 & Lawrence, Kans_ & Mar. $\tau$ & 4.2 & - \\
\hline 1882 & do & Apr. 10 & 4.3 & $\ldots$ \\
\hline 1883 & . do . & June 25 & 4.3 & - \\
\hline 1884 & . do & May 5 & 3.8 & $\cdots$ \\
\hline 1885 & $\ldots$ do & Apr. 27 & 3.7 & $-\ldots-$ \\
\hline 1886 & ....do ... & May 10 & 4.3 & $19,3 \% 0$ \\
\hline 1887 & . do ... & May 23 & 2.5 & 8,840 \\
\hline 1888 & $\ldots$ do . . & June 25 & 3.5 & 14,290 \\
\hline 1889 & ...do. & $\begin{cases}\text { May } & 13 \\
\text { July } & 22\end{cases}$ & 5.0 & 24,340 \\
\hline 1890 & $\ldots$ do $\ldots .$. & Jan. 13 & 2.8 & 10,370 \\
\hline 1891 & .... do & June 1 & 6.0 & a 35,598 \\
\hline 1892 & $\ldots$ do .... & May 16 & 8.8 & $\alpha 67,718$ \\
\hline 1893 & ....do & $\begin{cases}\text { June } & 5 \\
\text { July } & 3\end{cases}$ & 4.3 & 19,370 \\
\hline 1894 & $\ldots$ do .... & June 25 & 5.3 & 26,620 \\
\hline 1895 & .... do & $\begin{cases}\text { June } & 10 \\
\text { Aug. } & 19\end{cases}$ & 4.0 & 17,390 \\
\hline 1896 & $\ldots$ do & July 20 & 7.7 & $\alpha_{53}, 308$ \\
\hline 1897 & $\ldots$.... do ... & Apr. $\quad 26$ & 8.8 & ${ }^{a} 67,718$ \\
\hline 1898 & . do _ . . _ . & June 10 & 5.6 & 28,990 \\
\hline 1899 & Lecompton, Kans - & July 8 & 11.0 & 30,250 \\
\hline 1900 & . & Mar. 10 & 10.2 & 24,898 \\
\hline .1901 & $\ldots$......... & Apr. 14 & 10.0 & 25,000 \\
\hline 1902 & do _ . . . . & July 15 & $1 \% .6$ & 81,400 \\
\hline 1903 & ..... do _... & May 31 & 29.5 & $233,0 \% 0$ \\
\hline
\end{tabular}

a Computed from rating table for period May 15 to Aug. 31, 1896.

From this table it is seen that Kansas River at Lecompton was 12 feet higher during this flood than at any time during the twenty-two years covered by the record. The gage reading at this place ordinarily varies from 4 to 12 feet, but on May 31 it read $29 \frac{1}{2}$ feet, or $17 \frac{1}{2}$ feet higher than ordinary high water. The volume of water flowing in Kansas River on May 31 was nearly three times greater than at any other time during these twenty-two years.

\section{THE STORM.}

-Duration, extent, and depth of rainfall.-The period of excessive rainfall dates from May 16 to 31; the temperature during this time was abnormally high, the pressure was low, and a strong wind was 
blowing from the south, which developed tornadoes in parts of Iowa, Nebraska, and Kansas, killing 50 persons, injuring about 60 others, and destroying many thousands of dollars' worth of property. The daily rainfall during this period is shown in the following table, which is condensed from a table taken from the Monthly Weather Review for May, 1903:

Daily rainfall at Weather Bureau stations, May 16-31, 1903.

\begin{tabular}{|c|c|c|c|c|c|c|c|c|c|}
\hline Station. & 16. & 17. & 18. & 19. & 20. & 21. & 22. & 23. & 24. \\
\hline Williston, N. Dak & 0.16 & 0.08 & 0.34 & $\mathrm{~T}$. & T. & 0.94 & 1.49 & 0.12 & 0.02 \\
\hline Bismarck, N. Dak. & $\cdots$ & $\mathrm{T}$ & .86 & $\mathbf{T}$. & & .47 & 1.06 & & $\ldots$ \\
\hline Pierre, S. Dak & $\ldots$ & .26 & $-\ldots$ & $\ldots$ & 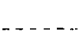 & .14 & .62 & 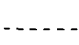 & .19 \\
\hline Rapid, S. Dak...- & .02 & .14 & .30 & 0.16 & - & .14 & .18 & & T. \\
\hline Huron, S. Dak & & & & $\mathrm{T}$. & & .16 & .50 & .34 & .24 \\
\hline Yankton, S. Dak.. & & 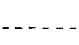 & . & .03 & T. & .39 & .76 & .68 & 1.00 \\
\hline St. Paul, Minn ... & 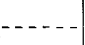 & T. & $\ldots$ & .10 & . & $\ldots$. & .01 & .64 & T. \\
\hline Moorhead, Minn & -- & .04 & .30 & .60 & & .24 & .42 & 1.50 & $\ldots$ \\
\hline Valentine, Nebr - & $\cdots$ & -1 & $\ldots \ldots$ & -1 & & .26 & .24 & T. & .10 \\
\hline North Platte. Nebr. . & T. & & & $\ldots$ & & .18 & .02 & & .02 \\
\hline Lincoln, Nebr ..... & . & $.0 \%$ & $\mathrm{~T}$ & .24 & & .56 & .79 & .28 & \\
\hline Omaha, Nebr .... & $\cdots$ & .16 & $\cdots$ & .04 & .10 & .64 & .80 & .01 & \\
\hline Concordiä, Kans & .30 & .14 & .78 & .04 & & .18 & 1.10 & .94 & $\ldots$ \\
\hline Topeka, Kans & T. & 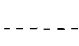 & $\cdots$ & .05 & & .50 & .04 & .64 & .85 \\
\hline Wichita, Kans. - & .01 & - & .98 & .10 & & 2.24 & .04 & 1.29 & $\mathbf{T}$ \\
\hline Dodge, Kans. & .14 & .10 & & & .10 & .58 & .06 & & \\
\hline Denver, Colo & $\mathbf{T}$ & T. & .01 & & & T. & T. & T. & $\ldots$ \\
\hline Pueblo, Colo ..... & & & $\cdots$ & & & $\cdots-$ & $\cdots$ & & $\ldots$ \\
\hline Cheyenne, Wyo... & .10 & .06 & .10 & - & & $\mathrm{T}$ & .01 & & $\mathbf{T}$ \\
\hline Oklahoma, Okla . & .58 & T. & .01 & T. & & .02 & 1.25 & T. & 4.06 \\
\hline Fort Worth, Tex. & $\mathbf{T}$ & .01 & - & $\ldots$ & & T. & $\ldots$ & $\mathbf{T}$. & $\mathrm{T}$. \\
\hline Dubuque, Iowa ... & & .08 & $\mathbf{T}$. & $\mathrm{T}$. & .01 & .06 & .50 & .02 & $\ldots$ \\
\hline Davenport, Iowa & & & $\mathbf{T}$. & T. & & .48 & .08 & .20 & .05 \\
\hline Des Moines, Iowa & & $.30 \cdot$ & T. & .04 & .02 & .06 & 1.38 & .12 & $\ldots .$. \\
\hline Keokuk, Iowa.... & & T. & .06 & T. & & .76 & .04 & .06 & 1.40 \\
\hline Sioux City, Iowa. & & .02 & .72 & 1.08 & & & .88 & .24 & .02 \\
\hline Kansas City, Mo . & & .02 & $\cdots$ & .06 & $\mathrm{~T}$ & .70 & .34 & .74 & .26 \\
\hline St. Louis, Mo .... & & $\ldots$. & .16 & .04 & .40 & .06 & & & T. \\
\hline Springfield, Mo ...... & T. & .04 & .02 &.$\tau 0$ & 1.06 & .35 & & & .06 \\
\hline Hannibal, Mo ....... & $\cdots$ & T. & .17 & .02 & & .49 & & .04 & 1.93 \\
\hline Fort Smith, Ark ..... & $\mathbf{T}$. & .08 & $\mathrm{~T}$ & 1.36 & T. & & $\mathbf{T}$ & & \\
\hline Little Rock, Ark .... & $\mathbf{T}$. & T. & T. & .54 & T. & & & & $\ldots$ \\
\hline
\end{tabular}


Daily rainfall at Weather Bureau stations, Inay 16-31, 1903-Continued.

\begin{tabular}{|c|c|c|c|c|c|c|c|c|}
\hline Station. & 25. & 26. & $2 t$. & 28. & 29. & 30. & 31. & Total. \\
\hline Williston, N. Dak & & 0.08 & & 0.60 & 0.04 & & & 3.87 \\
\hline Bismarck, N. Dak _ & & .20 & & & & & 0.50 & 3.09 \\
\hline Pierre, S. Dak . . . & & .04 & & & .46 & $\mathbf{T}$. & 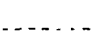 & 1.71 \\
\hline Rapid, S. Dak - - & 0.02 & $\ldots$ & 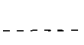 & $\mathbf{T}$. & .12 & 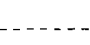 & .16 & $1 .{ }^{\circ} 4$ \\
\hline Huron, S. Dak & .08 & .24 & 0.01 & $\ldots$ & 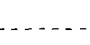 & $\ldots$ & $\ldots$ & 1.57 \\
\hline Yankton, S. Dak & $\ldots$ & .39 & -.39 & .43 & .40 & 0.10 & .03 & 4.55 \\
\hline St. Paul, Minnn . . . . & .62 & 1.04 & .24 & & & & & 2.65 \\
\hline Moorhead, Minn & & . & . & & $\ldots$ & -1 & . & 3.10 \\
\hline Valentine, Nebr .. & .04 & .50 & & $\ldots$ & .32 & .02 & $\ldots$ & 1.48 \\
\hline North Platte, Nebr.. & .08 & .18 & $\cdots$ & .01 & .43 & .06 & $\cdots$ & .98 \\
\hline Linc ln, Nebr.... & 1.37 & 1.03 & .43 & .15 & 1.94 & 1.13 & .10 & 8.09 \\
\hline Omaha, Nebr.... & .95 & .93 & .56 & $\mathrm{~T}$ & .52 & .40 & .10 & 5.21 \\
\hline Concordia, Kans_. & .16 & .96 & & 1.64 & 3.68 & .25 & .42 & 10.59 \\
\hline Topeka, Kans ... & .22 & .21 & .28 & .24 & 1.71 & .26 & .91 & 5.41 \\
\hline Wichita, Kans & $\ldots$ & .22 & $\ldots$ & .22 & .82 & .02 & .26 & 6.17 \\
\hline Dodge, Kans .... & $\cdots$ & .30 & .26 & .28 & .03 & .04 & ..... & 1.89 \\
\hline Denver, Colo _... . & .01 & T. & & .01 & .03 & & .28 & .34 \\
\hline Pueblo, Colo ... & $\ldots$ & .06 & 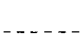 & .22 & $\mathrm{~T}$. & & & .28 \\
\hline Cheyenne, Wyo _- & $\ldots$ & $\mathbf{T}$ & $\ldots$ & .12 & T: & $\ldots$ & $\cdots$ & .39 \\
\hline Oklahoma, Okla & & T. & & .18 & 3.26 & .02 & $\mathbf{T}$. & 9.38 \\
\hline Fort Worth, Tex & & T. & & .68 & .46 & $\mathbf{T}$. & & 1.15 \\
\hline Dubuque, Iowa & .10 & 1.40 & 1.11 & .02 & $\mathrm{~T}$. & .34 & .12 & 3.76 \\
\hline Davenport, Iowa & .08 & $.8 \%$ & .42 & .38 & .32 & 2.02 & .46 & 5.36 \\
\hline Des Moines, Iowa & .18 & 2.08 & 1.38 & .06 & .94 & 2.52 & .30 & 9.38 \\
\hline Keokuk, Iowa & .52 & & .06 & & T. & $\mathbf{T}$ & .38 & 3.28 \\
\hline Sionx City, Iowa . & .01 & .47 & . & $\ldots$ & 2.27 & .42 & .08 & 6.21 \\
\hline Kansas City, Mo - & .22 & $\mathbf{T}$ & .76 & .01 & .23 & .68 & 1.03 & 5.10 \\
\hline St. Louis, Mo ... & .01 & T. & .12 & $\ldots-$ & .40 & T. & .42 & 1.61 \\
\hline Springfield, Mo ... & $\cdots$ & $\mathbf{T}$. & $\mathbf{T}$ & .20 & .80 & 1.54 & 1.66 & 6.43 \\
\hline Hannibal, Mo ..... & .06 & $\mathbf{T}$. & .04 & $\ldots$ & .28 & .32 & 1.61 & 3.96 \\
\hline Fort Smith, Ark & & $\mathbf{T}$. & .22 & .02 & 1.96 & .12 & .44 & 4.15 \\
\hline Little Rock, Ark ... & & & $\mathbf{T}$. & 1.14 & .68 & .91 & $\mathbf{T}$. & 3.27 \\
\hline
\end{tabular}

In the northeast-central part of Kansas in the vicinity of Concordia, where the precipitation was greatest, it rained daily for fifteen days, a total of about 10 inches in depth.

Rainfull during storm and during May compared.-The rainfall for the first half of May was considered above the normal for this month; the streams were carrying more than their normal amount, as can be seen from the gage readings in the table on pages 35,36 , and the ground storage available was small. It was this lack of surface and 


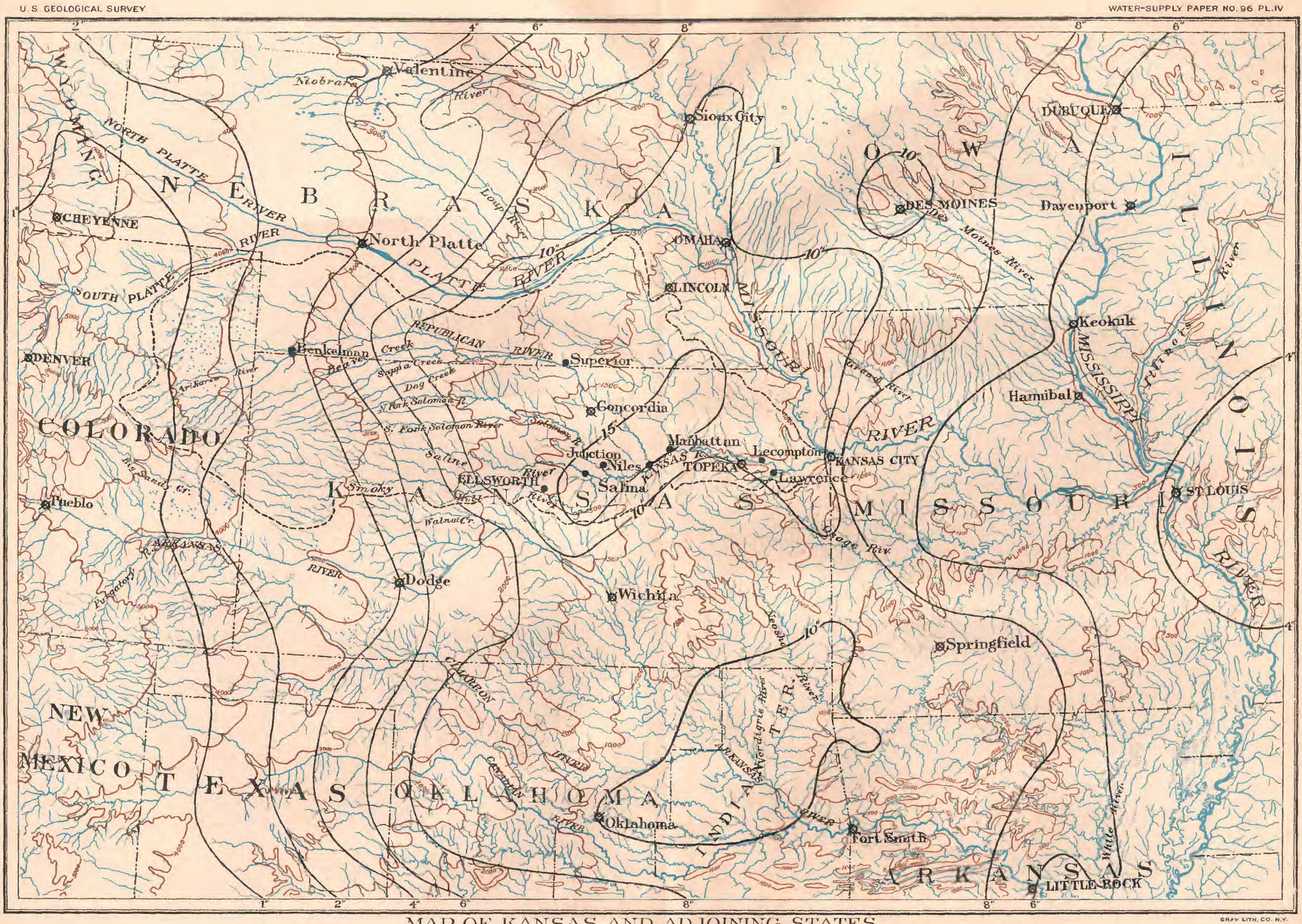

SHOWING THE WATERSHEDS OF THE KANSAS FNER AND OTHER STREAMS AFFECTED BY THE KANSAS FLOOD OF 1903

ALSO LINES OF EQI AT RAINFALL FOR MAY, AND THE LOCATION OF U.S. GEOLOGLCAL SURVEY GAGING STATIONS

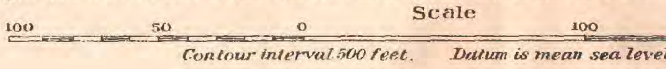


ground storage at the beginning of the flood period that made the flood of such exceptional magnitude.

The rainfall for May was over 17 inches at some stations. It was 17.34 inches at Salina, Kans.; 17.22 inches at Bradshaw, Nebr.; 15.45 inches at Thurman, Iowa; 17.29 inches at Blackburn, Okla. The area having a depth of 8 to 17 inches of rainfall during May covers the eastern two-thirds of Kansas, northern Indian Territory and Oklahoma, western Arkansas and Missouri, eastern two-thirds of Nebraska, western half of Iowa, and small parts of southern Wisconsin and southeastern Minnesota.' The storm was more nearly central over Kansas River and tributary watersheds than over any other watershed of this area, hence the Kansas River flood was greater than that of any other stream. On the accompanying map (Pl. IV) are shown the watersheds affected, the lines of equal rainfall for May, and the location of the United States Geological Survey gaging stations.

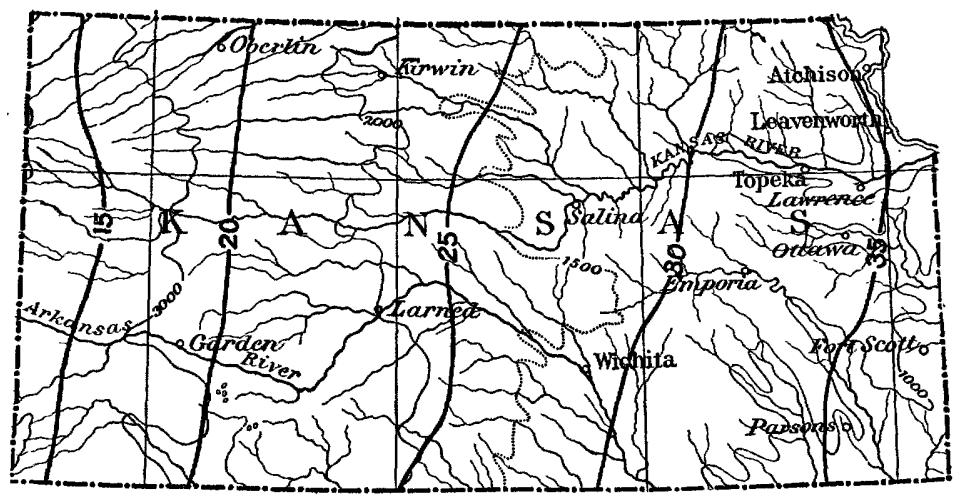

FrG. 2.-Mean annual rainfall lines over Kansas.

Curves of annual rainfall and rainfall during May compared.Fig. 2 shows the lines of mean annual rainfall over Kansas. This mean annual rainfall is seen to decrease from about 35 inches in the eastern part of the Kansas River watershed to about 12 inches in the western part. More than half, therefore, of the ordinary mean annual rainfall over the eastern half of the Kansas River watershed fell during May, 1903, whereas, ordinarily, only about 14 per cent of this falls during that month.

\section{CHARACTER OF WATERSHED FLOODED.}

Location, extent, and topography.-Kansas River and its tributaries (Blue, Republican, Solomon, Saline, and Smoky Hill rivers), along which the greatest amount of damage was done by this flood, drain a long, comparatively narrow strip of country lying between Platte River on the north and Arkansas River on the south, and extending from Missouri River on the east to the foothills of the 
Rocky Mountains in Colorado on the west. The length from east to west is 485 miles, and the width varies from 140 to 190 miles; the total

- area drained is 61,440 square miles-?,459 square miles in Colorado, 17,455 square miles in Nebraska, and 34,526 square miles in Kansas. This country is rolling prairie, with little timber except narrow strips along the streams in the eastern half of the State; the soil is very productive, especially in the river bottoms, and is mostly under cultivation where the rainfall is sufficient to mature crops. The eastern third of this area is covered with a tough buffalo-grass sod. The altitude on Gannett's contour map of the United States varies from 750 feet at Kansas City to 5,000 feet in the western part in Colorado. The 500-foot contonr lines are shown in Pl. IV. The surface is seen to rise at a gradually increasing rate from east to west; the valleys are wide and comparatively shallow, with very little opportunity for storage of water.

Description of Kansas River.-Kansas River differs greatly from both the Platte on the north and the Arkansas on the south, in that it is wholly within the plains area and has no mountain drainage; its entire water supply comes from rain falling on the plains within its drainage area. The surface storage is very small, there being no lakes, ponds, or swamps to hold back the flow, and no mountains to hold back the winter precipitation. The minimum flow is, therefore, very small and the flood flow very large. The term "Kansas" is applied to this stream only after the Smoky Hill joins the Republican near Manhattan; the Solomon and the Saline are tributaries of the Smoky Hill. The principal tributaries of the Kansas are the Blue and the Delaware on the north and the Wakarusa on the sonth. The areas drained by these streams in the different states are given in the table below:

Drainage areas in Kansas River basin.

\begin{tabular}{|c|c|c|c|c|}
\hline Basin. & $\begin{array}{l}\text { Total } \\
\text { area. }\end{array}$ & $\begin{array}{l}\text { Area in } \\
\text { Kansas. }\end{array}$ & $\begin{array}{c}\text { Area in } \\
\text { Ne- } \\
\text { braska. }\end{array}$ & $\begin{array}{l}\text { Area in } \\
\text { Colorado. }\end{array}$ \\
\hline Kansas River entire $\ldots \ldots \ldots$ & $\begin{array}{c}s q . \text { miles. } \\
61,440\end{array}$ & $\begin{array}{c}s q . \text { miles. } \\
34,526\end{array}$ & $\begin{array}{c}s q . \text { miles. } \\
17,455\end{array}$ & $\begin{array}{r}\text { Sq. mites. } \\
9,459\end{array}$ \\
\hline Kansas River above Laẉrence. . & 59,841 & $33,92 \pi$ & 17,455 & 9,459 \\
\hline Kansas River above Lecompton .... . . . . & 58,550 & 31,636 & 17,455 & 9,459 \\
\hline Blue River above Manhattan ...... & 9,490 & 2,450 & 7,040 & \\
\hline Republican River entire . . . . . . . . & 25,837 & 7,496 & 10.415 & 7,926 \\
\hline Republican River above Superior & $22,34 i$ & & & \\
\hline Smoky Hill River entire.......... & 20,428 & 18,895 & & 1,533 \\
\hline Smoky Hill River above Ellsworth. . & 7,980 & 6,447 & & \\
\hline Saline River entire $\ldots \ldots \ldots$ & 3,311 & 3,311 & & 1,533 \\
\hline Solomon River entire $\ldots . . . . . .$. & 6,882 & 6,882 & & \\
\hline Solomon River above gaging station & 6,815 & & & \\
\hline Kansas River (proper) above Lecompton ... & 5,123 & & & \\
\hline
\end{tabular}


Kansas River above Lawrence meanders through the bottom land, crossing and recrossing it, but as a rule being closer to the south border than to the north. This bottom land, which includes the land adjacent to the river and not more than 20 feet in elevation above it, is inainly alluvial matter and varies in width from 1 to 4 miles. The bed is mainly shifting, saudy, alluvial material, though in a few places it is rocky. The banks as a rule are not more than 10 feet in height except where the river runs near the bluffs, where they are from 30 to 40 feet high. They are easily eroded by the current, and frequently a new channel is formed and a considerable amount of land washed away.

\section{THE FLOOD.}

Reasons for magnitude of flood.- The unprecedented rainfall of 5 to 10 inches in sixteen days, falling on a watershed with practically no surface storage, and at a time when the flow of. the streams was considerably above their normal and the ground well saturated with water, was sure to produce an enormous flood. The Kansas daily newspapers of the 24 th to 27 th report heavy rain and wind storms, with loss of life and property.

Flood in vicinity of Topela.-On the 27th the Topeka Capital reports " 200 homeless in Salina, Kans., from flood due to rain the previous night;" also several tornadoes in Kansas and Iowa, in which a number of persons were killed. The mean reading of the United States Geological Survey gage near Salina, on Saline River, for the 27th, was 32.6 feet, only about 1 foot less than the maximum during this flood. On the 28th the same paper reports the streams in Missouri, Iowa, Nebraska, and Oklahoma out of their banks. The mean daily gage reading at Lecompton for this date is 18 feet, about 1 foot higher than at any time during the.previous twenty-two years. On May 29 the same paper reported "the worst flood situation that has ever confronted Kansas for many years; bridges and tracks under water; many families driven from their homes; thousands of acres of corn ruined, and greater floods expected on account of continued heavy rain." The mean daily gage reading at Lecompton for this date was 21.1 feet, which is $3 \frac{1}{2}$ feet higher than the highest in the twenty-two years' record. On the 30th the same paper reports "practically all of North Topeka submerged; 4,000 North Topeka persons driven from their homes, and 1,500 houses partly submerged." The mean daily gage height at Lecompton for this date is 24 feet, which is 6.4 feet higher than the highest reading in the twenty-two years' record. On Sunday, May 31, the flood in Kansas River reached its maximum height. The mean reading of the Lecompton gage for this date was 28.75 feet and the maximum 29.50 , which is about 12 feet higher than the highest gage reading at this place in twenty-two years. The Topeka Capital of this date states that over the highest part of North Topeka the river was flowing 5 feet deep. The water had reached the eaves of many houses supposed to be above high water. 
Flood in the vicinity of Kansas City.-Missouri River at Kansas City reached danger line-21 feet gage height-on the 27th of May. On the morning of the 31st it reached $27 \frac{1}{2}$ feet, and on June 1 it reached its highest point- 35 feet-which is 14 feet above danger line and only 2 feet below the highest point reached by the great flood of June $90,18 \pm 4$.

The Kansas City Times of June 1 described the condition in Kansas City as follows:

Kansas City passed yesterday the most disastrous day in its history; and to-day an emergency confronts its people greater than they have ever known before; problems, too, that affect the welfare of all of the city are to be met, and they must be met promptly. All Saturday night and all yesterday the torrents swept down the Missouri and Kansas until the valleys of the Kansas and Missouri were a solid mass of raging water from bluff to bluff. On the Union Depot platform there were 6 feet in depth of water, and all over the west bottoms, the center of the heavy wholesale and manufacturing business of the city, there was an equal or greater depth. Several lives it is known have been lost, and many more it is feared have perished. Hundreds were ressued from impending death, but late last night people standing on the west bluff could hear the agonizing cries for help from men and women in houses ont on the wide expanse of water, but what the loss of life has been can not bə accurately known until the water recedes. Early yesterday frame and other nnstable structures in Argentine and Armourdale, that had been partly submerged for several days. began to leave their foundations and float away, thus a great mass of wreckage collected; it swept down on the bridges that spanned the Kansas. First the Kansas City Belt Line bridge above the stock yards went ont, later the bridges at the stock yards and the Union Pacific Railroad bridge. The mass of wreckage grew. Soon it was joined by the great oil tank that had floated down from the Armonrdale oil plant. which surged against the double-deck Central Avenue bridge, which carried the electric railway across to Kansas City, and the bridge went down as if made of paper. Five more bridges between this point and the mouth of the Kansas wera swept away, and worst of all the bridge which carried the flow line of the Kansas City waterworks went down, carrying with it the 36 -inch pipe which furnishes 200,000 people with their water supply.

In the Kansas City Times of June 10 is the following statement of the Erecutive Relief Committee of Kansas City, Kans:

Two entire wards and parts of two others, comprising, by the official census of March, 1903, at least 23,000 out of the population of 60,000 in the whole city, are made homeless and destitute. Hundreds of their houses have been swept away, and those that remain have been under 10 to 20 feet of water, and left with a deposit of silt both inside and out from 1 to 3 feet in depth. In most instances persons were able to save only the clothing they wore. Their household goods and clothing have been swept away or destroyed by the water and mud.

Flood in vicinity of Laurence.-Some idea of the magnitude of the flood and its effect in the vicinity of Lawrence, Kans., can be gathered from the following notes taken from the Lawrence Daily Journal:

At 3 a. m., May 29, the pumping plant which supplies the city with water was compelled to shut down on account of the very high water, and it could not resume pumping again until June 6 . At 8 a. $\mathrm{m}$. the electric-light.plant was 
compelled to shut down. At noon the water broke through the Union Pacific embankment, flooding North Lawrence. The Santa Fe trains could not pass Lake View, 4 miles west of Lawrence, on the main line.

At 9 a. m., May 30. Congressman Bowersock's flouring mill was swept off from its foundation, and in a few minutes not a vestige of it was left. The flume also was destroyed, but the dam was practically uninjured.

Six hundred feet of the Eudora highway bridge was swept away this morning.

* * * The water is running over the Lecompton highway bridge, and the floor is being taken up to save the structure being swept away. *** During the day 50 buildings were counted as they passed over the dam.

June 1: The scene in North Lawrence is one of destruction and desolation. There is probably not a building standing on its foundation west of Bridge street, save the few structures north of the Usher block, and there is hardly a habitation of any kind for man or beast in that part of the city. The part north of the Union Pacific depot has also been swept, and numerous houses there have been carried from their foundations down the streets. The Griffin ice houses and their contents, the transfer barns and their equipment, including several head of horses, the Union Pacific freight depot, and many of the larger frame stores were carried down by the strean, while the foundations of brick and stone structures softened, and the crumbling ruins are all that is left to tell the story of their existence.

There was very little furniture or personal property saved. No opportunity was afforded to get live stock on higher ground. * * * At 5.30 Sunday evening the north span of the Lawrence highway bridge was swept from its piers by the house of Mr. William Parsons striking it as it was being swept away by the raging torrent. This house had only been cleserted by Mr. Parsons and his family on Friday, and contained all of its furniture. If it had not been for the forethought of the authorities in uncoupling this bridge span from the others in anticipation of such an accident, the damage to the bridge might have been much greater.

Flood in vicinity of St. Louis.-At St. Louis the highest stage of the river was 38 feet, or half a foot higher than the flood of 1858 and 3.4 feet below the flood stage of 1844 .

The Journal of Agriculture for June contains the following:

The great flood of 1844 , although it reached a higher point, did comparatively little damage, as the localities covered by it were almost uninhabited at that time. Kansas City, with its great railroad and packing industries, was not even dreamed of and was bare prairie land. East. St. Louis, which is now a big city engulfed in the flood, had no existence, but was simply an entrance' to St. Louis. * * * So the former floods, however high their waters, could inflict but small loss compared with that now deluging so many thousand miles of fertile country and cities teeming with large population. The money loss involved is simply enormous, but the most lamentable feature is the loss of life. *** The damage inflicted by these periodic inundations seems to be irremediable. The ingenuity of man has not yet been able to suggest any plan by which the excessive rainfall which causes floods can be subjected to control. To anyone. who saw the mighty Missouri at its highest flood near the junction with the Mississippi the bare idea of storage reservoirs and dams is absurd. Its volume is so vast that probably no valley in our country could contain it, even if it were at all possible to restrain it by dams and bari iers. The Missouri River defies restraint. and all that can possibly be done to mitigate its ravages when on the rampage is to be prepared for it generally and by building railroads and dwellings in future higher than its recorded heights. 


\section{DESTRUCTION WROUGHT BY THE FLOOD.}

The destruction wrought by the flood may be treated under three headings: First, drowning and wetting by the water; second; pressure and transportation by the water; third, scouring by the water.

By drouning and wetting.-It is seen from table on page 22 that for eleven successive days (May 28 to June 7) Kansas River was higher than it had been in the previous twenty-two years covered by the record. The height of the water above previous high-water mark was $6 \frac{1}{2}$ feet for six consecutive days, 8.7 feet for four consecutive days, and 9.6 feet for two days. When it is remembered that the slope of the country at right angles to the river is very gentle, it will readily be seen why a very large part of this river bottom was submerged for several days. Over a considerable part of the area the velocity was such as to cause much damage by its scour; over the remainder of it the damage was due mainly to the drowning or soaking action. Farmers report the loss of much stock, and at the packing houses in Kansas City a large number were lost. All crops covered by the water were a total loss; young orchards surrounded by water were ruined; many thousand barrels of corn stored in cribs, and household furniture and clothing were destroyed. Several business houses in North Topeka and Kansas City suffered heavily, as goods in basements and first stories of buildings were soaked with the muddy water for several days. The very high water flooded pumping plants, electriclight stations, gas plants, and small power plants, leaving eities without water for drinking purposes and without light, and depriving manufacturing industries of power.

By pressure and transportation.--Much property was destroyed by the transporting power of the water. Many wooden buildings in Lawrence, Topekit, and Kansas City were taken from their fcundations and swept bodily down with the current or dashed to pieces against trees or other buildings. Some buildings not thus entirely lost were moved some distance from their foundations and badly damaged; several feet of sand was piled around some of them, while large holes were scoured around others. Some brick buildings were undermined and left uninhabitable. A large quantity of this floating material was swept down the river and collected against bridges, which were subjected to tremendous strain, as they acted as dams. Many of the railroad companies, anticipating the flood, had loaded their bridges with engines and flat cars. The water passed over the tops of these cars and the drift formed a dam against them. Of the 16 bridges spanning Kansas River from Armourdale to its mouth, all except one, the Missouri Pacific Railway bridge (shown in Pl. V, $B$ ), were in part or wholly destroyed. The location of this bridge is shown on the map (Pl. VI, p. 32). Within two hours 16 bridges, within a distance of only 4 miles, were swept away. The Missouri 


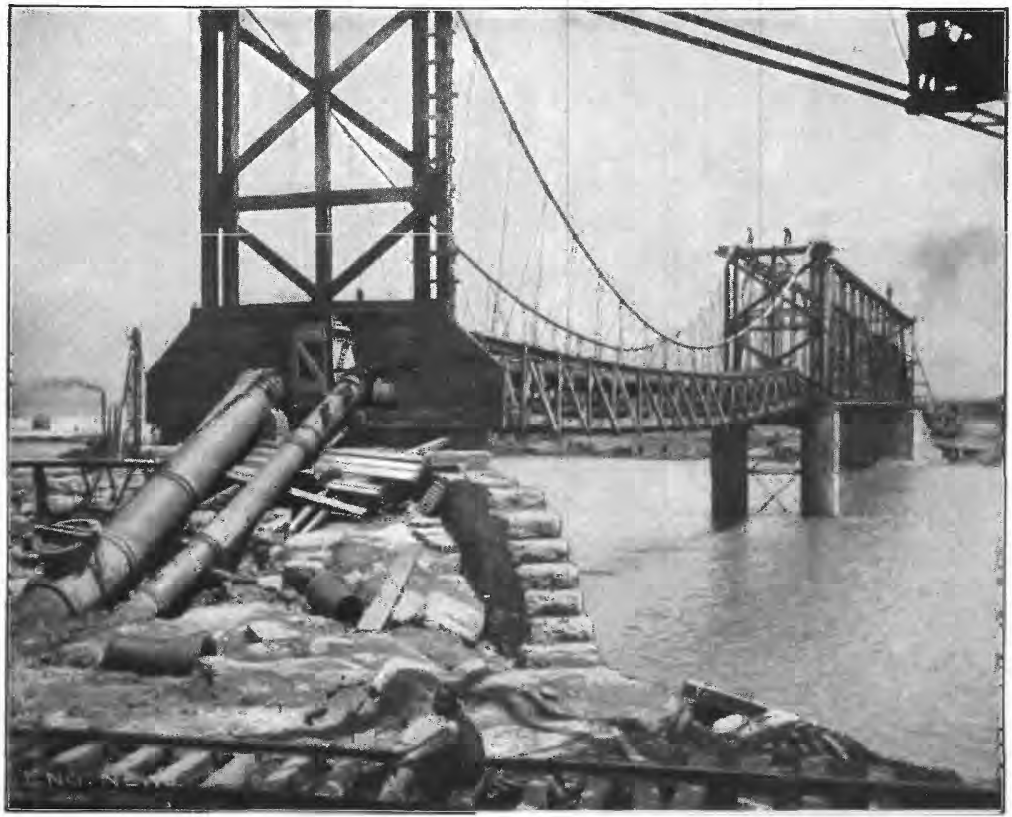

A. VIEW OF "FLOW-LINE" BRIDGE, REPAIRED WITH SUSPENSION SPAN.

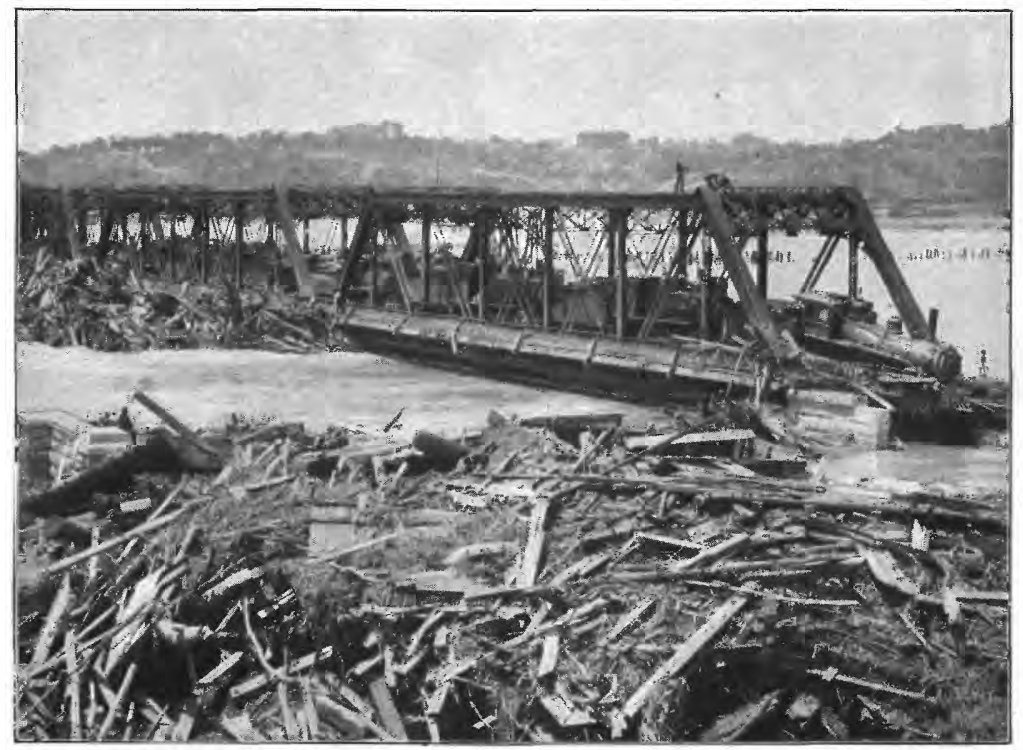

B. VIEW OF MISSOURI PACIFIC RAILROAD BRIDGE AT KANSAS CITY AFTER THE FLOOD. 
Pacific bridge, which withstood the flood, is a very heavy, double-track bridge, and was loaded from end to end with locomotives. Some idea can be formed of the débris which came down the river from the amonnt which was lodged against the piers and abutments of this bridge. (See Pl. V, B.) The damaged bridges were nearly all steel structures of about 200 feet span, resting on masonry or metal piers. Several of them were double-track structures. The cost of replacing them is estimated to be from one and a quarter to one and a half million dollars. One of the bridges destroyed carried a 36-inch watersupply pipe for supplying Kansas City, Mo., and a part of Kansas City, Kans., with water. As a result of its failure, the whole city was without water for twelve days, and the electric-light company, gas company, and street railways were compelled to shut down for lack of water.

The highway bridge at Eudora was partly washed away. The highway bridge at Lawrence had one span washed away. The river at this point made a new ehannel around the north end of the bridge, washing away the Union Pacific freight station and several other structures. In September the total flow of the river was passing through this new channel.

The highway bridge at Lecompton was uninjured, but a channel was scoured around the north end of it. All the bridges across the Kansas at Topeka were destroyed except the Melan arch bridge, and the approaches of that were so badly damaged that for several days the only means of access between the north and south parts of the city was by boat.

By scouring action.- The damage due to the scouring action of the flood was very great, the railroad companies being the heaviest losers in this respect. Many miles of railway track located near Kansas River were washed away or badly undermined.

It can be shown mathematically that the increase in the scouring action of water and its transporting power is proportional to the sixth power of the velocity. If, for example, the velocity along the bed of a stream at a given point is 2 feet per second at ordinary stage, and during the flood the velocity is found to be 4 feet per second, then the cutting or scouring action of the water for the 4 feet velocity during flood is sixty-four times that of the 2 feet velocity at ordinary stage, and bowlders will be carried along during the flood that are sixty-four times as heavy as those carried at ordinary stage.

However, the power of a stream in flood to cut river banks and make new channels, as compared with its action at ordinary flow, varies at a much larger rate than as the sixth power of its velocity, because the toughness of a bank of alluvial material and its ability to resist scour decreases very rapidly from the bottom toward the top. Take, for example, the case of a stream flowing in a channel with banks 10 feet high. When the water is 2 feet deep it comes in contact 
with only the lower 2 feet of the bank, which is tough and firm. When the river rises 3 feet, the water flows more rapidly and comes in contact with a part of the bank which is 5 feet up from the bed, and which is less tough and more readily scoured. When water rises to 8 feet or more, the velocity is several times greater than at the shallow depth and the water comes in contact with a part of the bank much more easily eroded than the portion near the bottom; hence the wear is very rapid during a flood, and in a few hours deep channels are cut and acres of land washed away. This cutting action is greatest just below a bend in the stream. Here water tends to continue moving in a straight course, and hence strikes the concave surface of the bank just below the bend. When, as during the recent flood, the river rises high above its banks, it takes a straight course, regardless of its banks, and often does much damage where it was supposed the water could never reach. The new channel through North Lawrence around the dam is 200 feet wide and so deep that the whole flow of the river passes through it. The bed of the Kansas at Lecompton Bridge was scoured to a depth of from 3 to 6 feet during the flood; a depth of several feet was scoured also for several hundred feet in width north of the north abutment. A large amount of material was scoured from the left bank of Republican River at the gaging station at Junction, and, in fact, in many places along the stream there is evidence of a very considerable amount of material having been carried away. In many places material has been deposited as well. Some of this deposit is fine silt which will enrich the land, but often it is sand which will injure it to a considerable extent.

\section{HYDROGRA PHIC DATA OF KANSAS RIVERS.}

\section{METHOD OF OBTAINING DATA.}

The United States Geological Survey has at present eight gaging stations in the Kansas River basin. Four of these are in the Republican River basin, two at Benkelman, Nebr., one at Superior, Nebr., near the State line, and one at the mouth of the river near Junction, Kans. There is one on the Smoky Hill River at Ellsworth, one on the Saline near its mouth, one on the Solomon near its mouth, one on the Blue near its mouth, and one on the Kansas at Lecompton. Six of these stations have been in operation about eight years. At each of these stations there is a gage for measuring the rise and fall of the water surface. This gage is read twice a day by a person living near by, and a copy of the reading is sent at the end of each week to a resident hydrographer who has charge of all the stations in that State. The resident hydrographer visits each station several times a year to measure the volume of water flowing and inspect the station. He measures the depth at 5-foot intervals across the stream and computes the area of the prism of water flowing. 


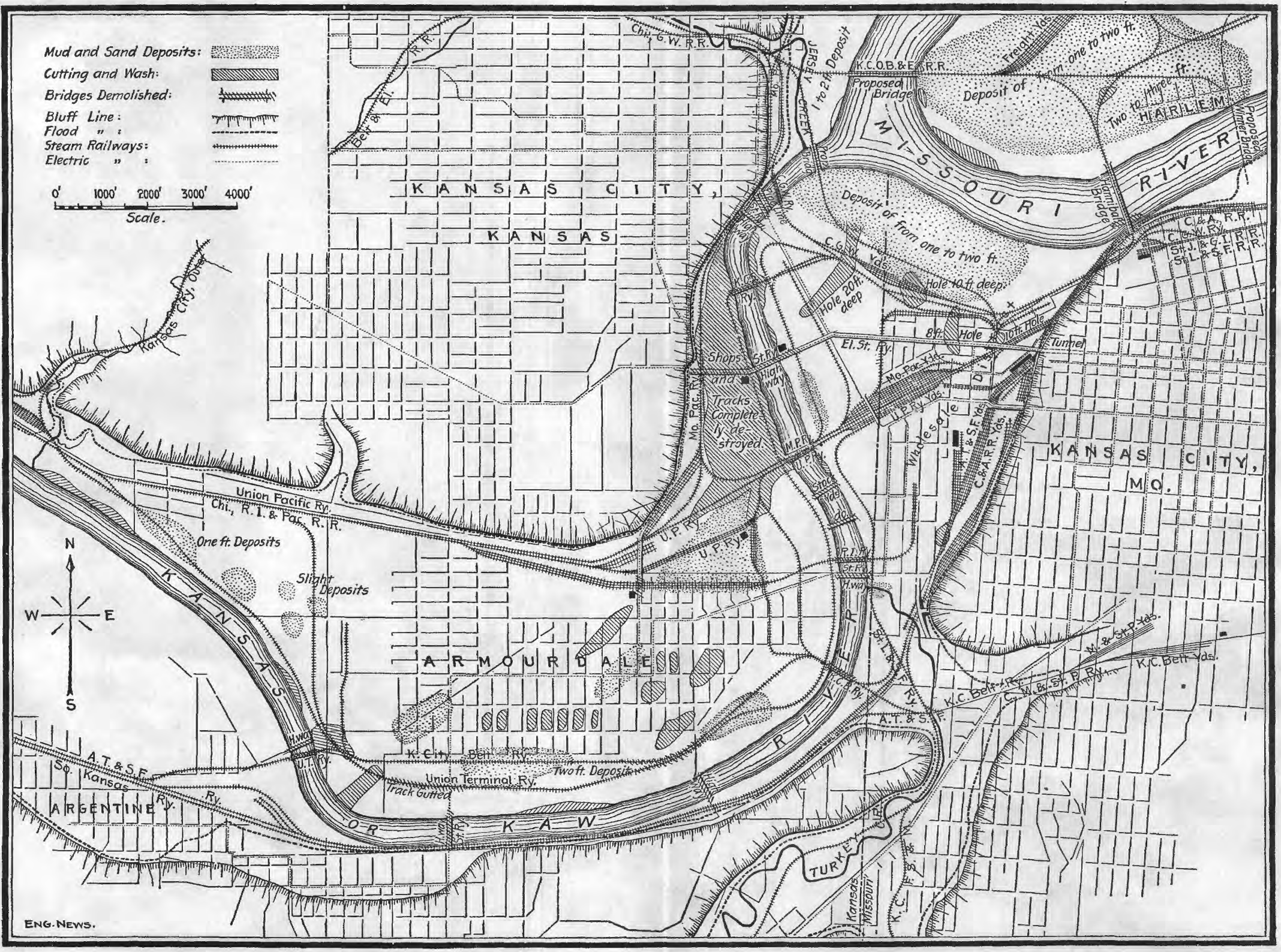

MAP OF KANSAS CITY, SHOWING FLOODED AREA. 
He also measures the velocity at a sufficient number of points in the cross section to enable him to compute the mean velocity of the prism of flowing water. From the cross section and mean velocity he computes the volume passing down the stream for that particular gage height and stream stage. After he has obtained the volume of flow for all stages, he prepares a station rating table which gives the volume of flow for each gage reading. The mean volume flowing per day is then taken from this table, using as a gage reading the mean of the gage readings of the morning and evening. Having the mean daily flow, the monthly and yearly flow are easily computed. The tables (pp. 37-68) give the maximum and minimum monthly flow, as well as the mean, for purposes of comparison; they give the total flow in acre-feet, for purposes of storage; the run-off per square mile, to show the number of square miles necessary to yield a given flow per second, also the depth in inches of run-off, for the purpose of showing the proportion of rainfall that is flowing in the stream.

The table on pages 35,36 gives the mean daily gage heights and corresponding estimated discharges for May and June, 1903, at seven of the gaging stations in the Kansas River basin. These flood discharges are very difficult to measure, or even to estimate. In fact, it was impossible to measure the velocity, or even to visit some of the stations during this flood. During floods there is always more or less back water, and consequent retarding of velocity, so that usually the volume of water flowing is much less than the flooded land indicates; much of the overflow water has very little velocity, so that flood estimates made by eye are, as a rule, too large. In computing the discharges in the table the station-rating table has been extended to the greatest gage height, assuming that the banks were not overflowed, and a certain percentage of the discharge has been added, depending on the magnitude of the overflow and the velocity as shown by the scour. The difficulty of computing accurately the discharge during this flood is further complicated by the change in the bed of the stream during the flood. The station-rating curve for 1902 can not be used for computing the discharge for 1903, and the discharge measurements made in 1903 are too few to enable a good station-rating table to be prepared. At the Lecompton and Junction stations the river bed was scoured, so that the discharge after the flood was greater than before it for a given gage reading. At Salina, Niles, and Ellsworth the channel was filled in to such an extent at some point below the station that the discharge is less for a given gage reading since the flood than before it. The bed of the stream at the Manhattan station changed very little during this flood. The results given in the table are believed to be under- rather than over-estimates.

This table is arranged so as to show the increase in flow from the western part of the drainage basin to the eastern part. The run-off per square mile in May increases from 0.30 second-foot at Ellsworth IRR $96-04-3$ 
in the western part to 2.01 second-feet at Manhattan, and in June increases from 0.12 second-foot at Ellsworth to 1.73 second-feet at Manhattan.

Among the many interesting facts shown by the table the following may be noted: (1) The great volume of flood flow as compared with the ordinary flow. (2) The sudden changes in stream stage-as, for example, the change from 3.30 feet gage height on May 27, at Ellsworth to 15.40 feet on the 28th. (3) The large range of stage of stream-as, for example, the change from 5.90 to 36.50 feet at the station on Blue River.

It is seen from the Ellsworth record that this flood extended only a short distance west of Ellsworth, Kans., that is, it did not extend beyond the eastern two-thirds of the State of Kansas. 


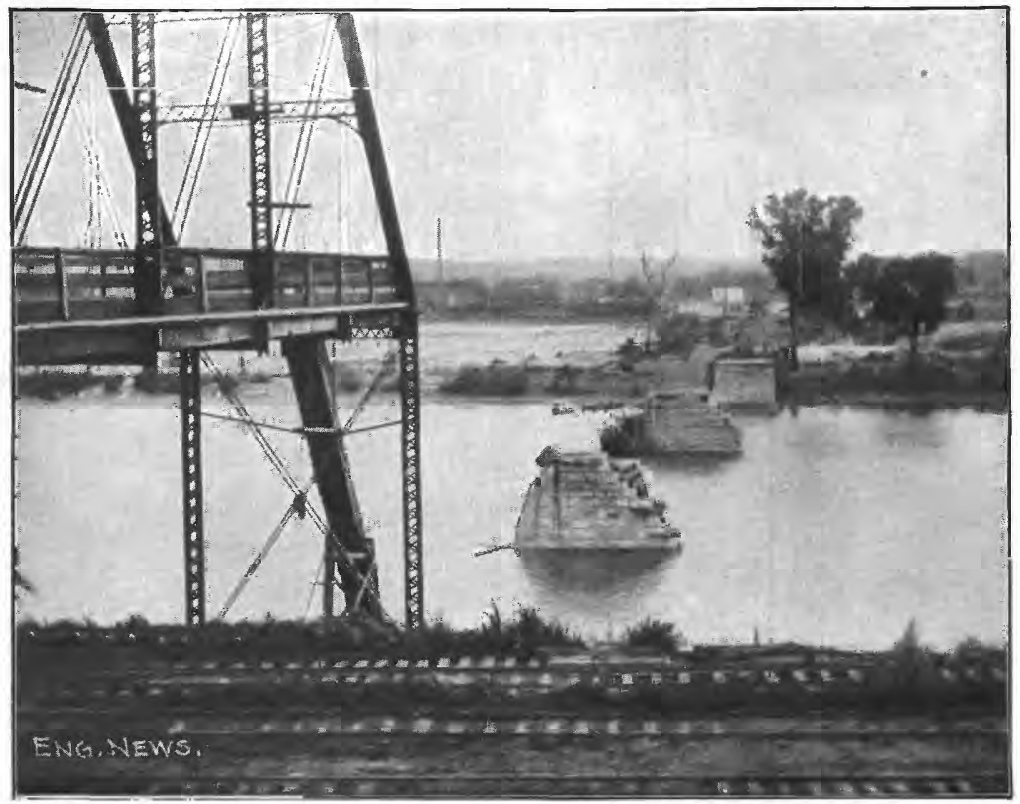

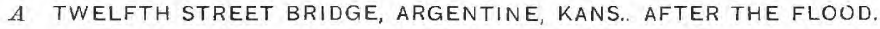

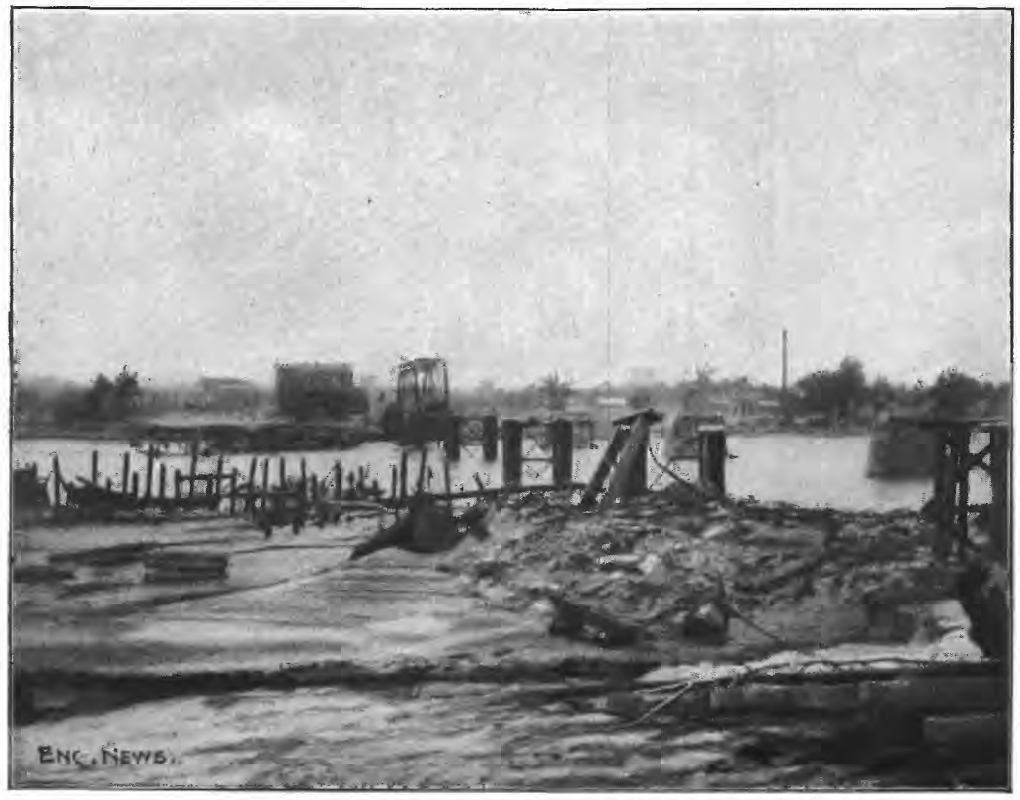

B. KANSAS CITY SOUTHERN RAILROAD BRIDGE, KANSAS CITY, AFTER THE FLOOD. 


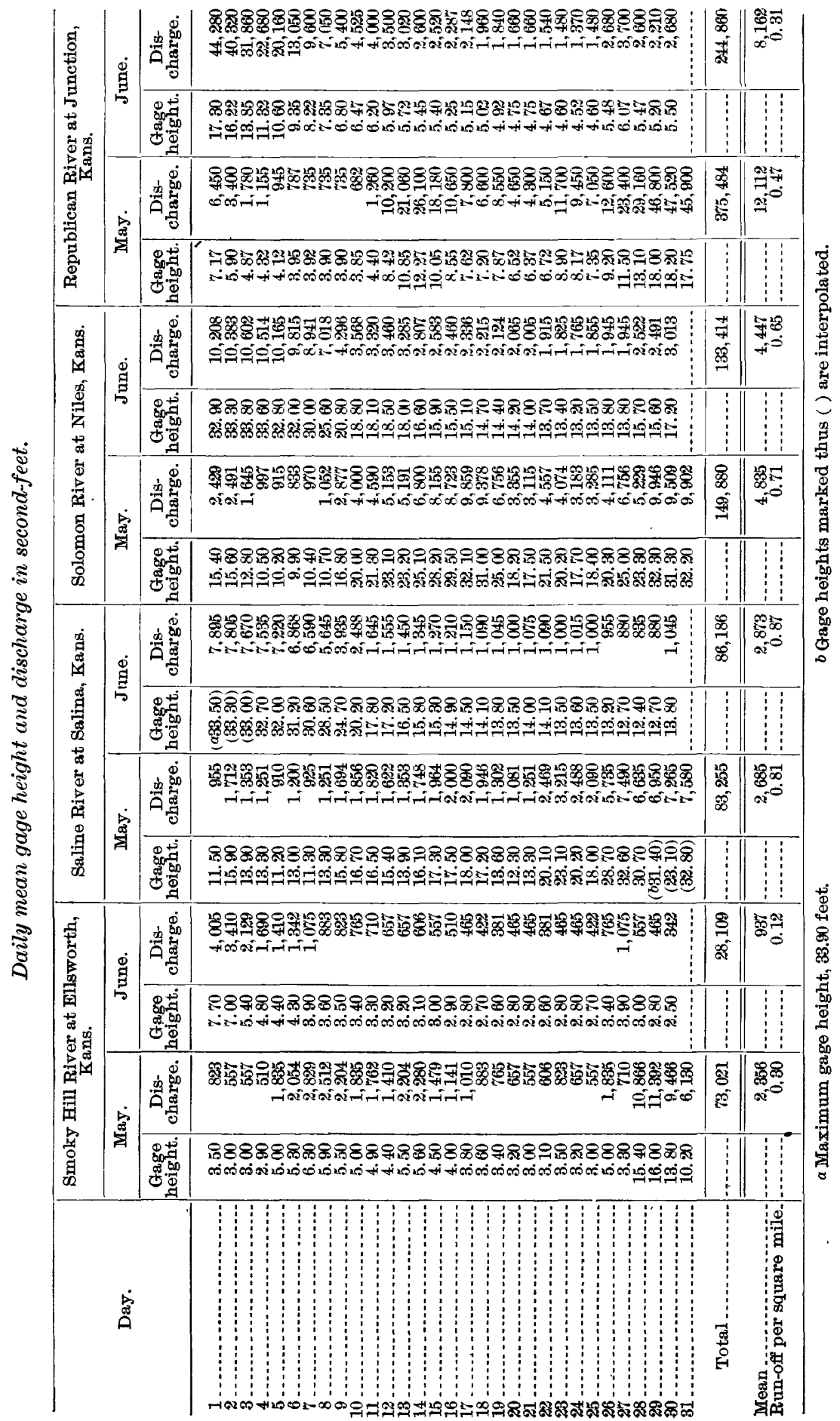




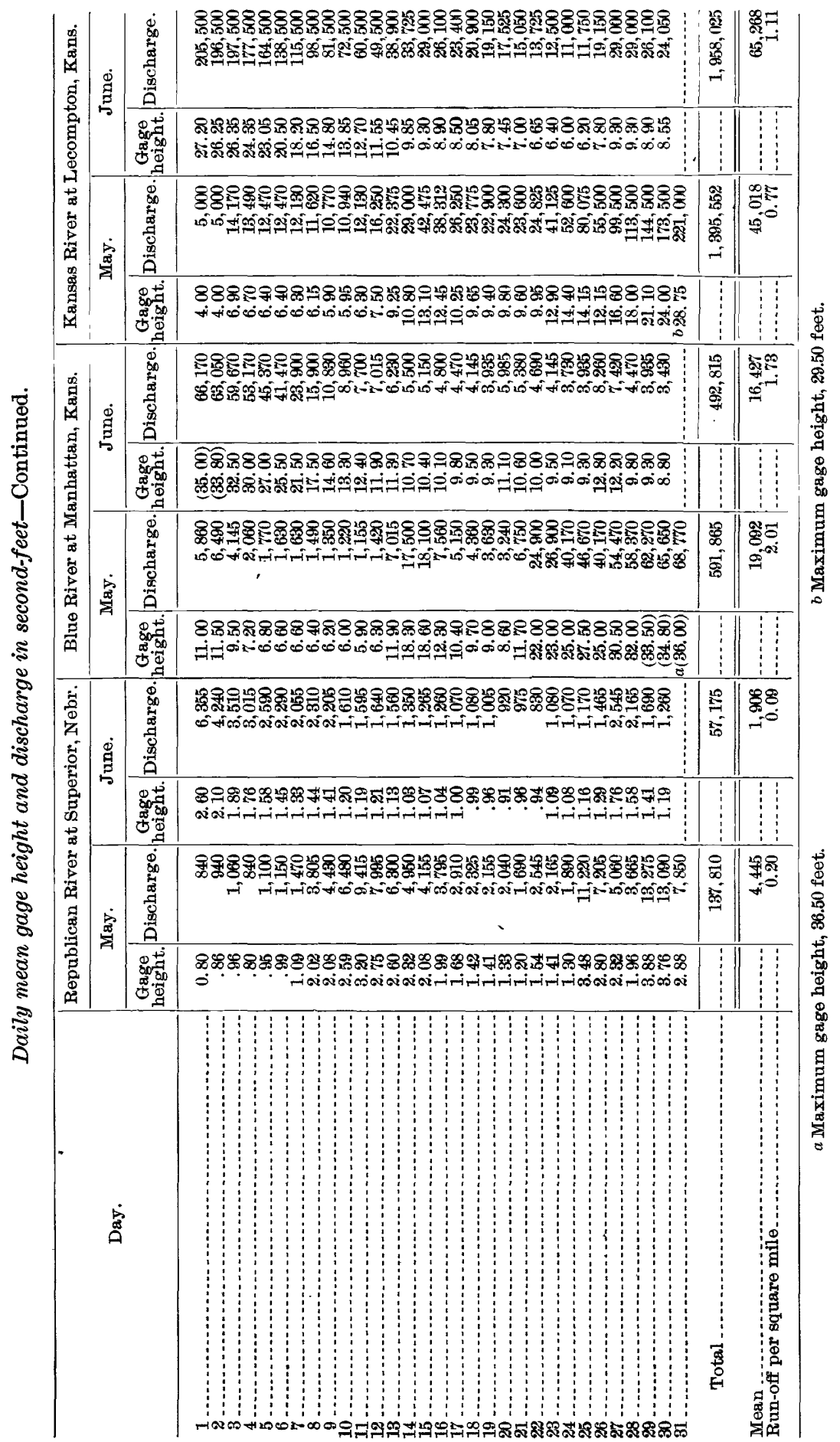




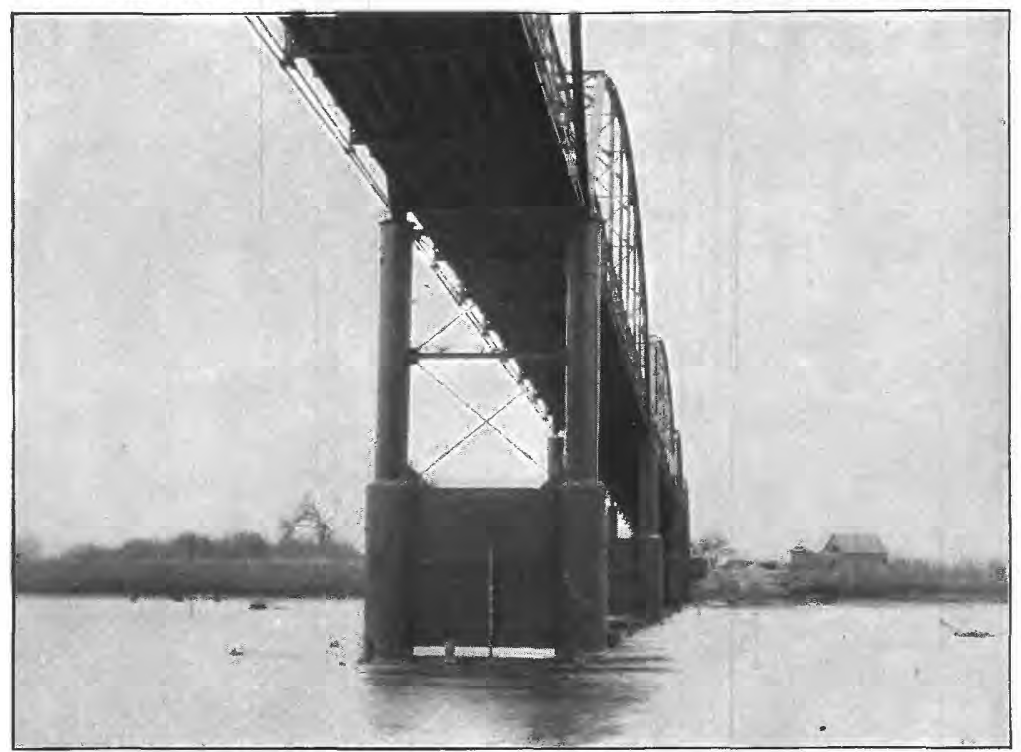

A. BRIDGE AT LAWRENCE, KANS.

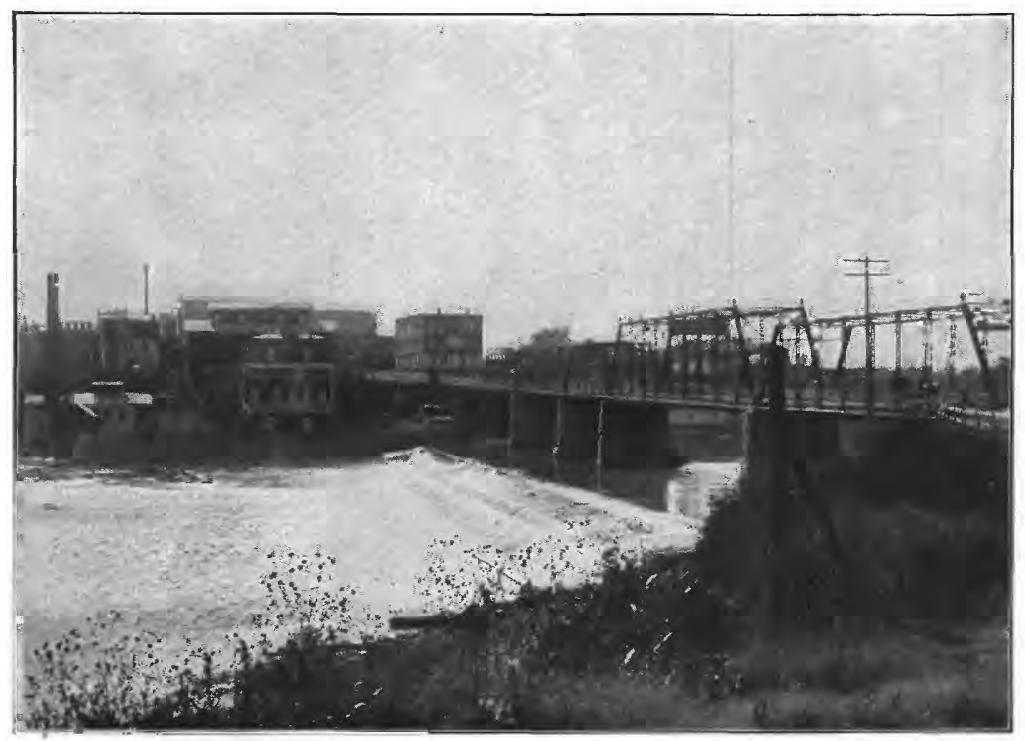

B. BRIDGE AND GAGE, LECOMPTON, KANS. 
DESCRIPTION OF STATIONS AND DISCHARGE TABLES.

KANSAS RIVER AT LAWRENCE AND LECOMPTON, KANS.

The first gaging station on Kansas River was established in 1880 by Mr. J. D. Bowersock at the highway bridge at Lawrence, Kans. The gage consisted of a vertical timber marked to feet and inches and fastened to the lower side of the pier adjacent to the right bank. This gage was read daily, or oftener, and the readings recorded whenever there was any material change in them until August, 1895, when this place was selected as a United States Geological Survey gaging station. From this date to April 16, 1899, gage readings were taken twice daily, a station-rating curve prepared, and the run-off computed. On account of the sluggish flow at this place during low stages it was deemed advisable to move this station to the highway bridge at Lecompton. This bridge and the gage are shown in Pl. VII, B, p. 34 . The channel at this place is about 800 feet wide, broken by four metal piers. The bridge is only a short distance from a bend and is somewhat oblique to the course of the stream. The bed is mainly sand and was scoured out a considerable amount during the recent flood. The gage is a 2 by 4 inch timber bolted to the metal pier adjacent to the right bank. The pier on the right bank is marked to half feet for high-water gage readings. The low-water flow is practically the same at Lecompton as at Lawrence, but during high stages Delaware River contributes a considerable amount between these places.

The following tables give run-off at Lawrence and Lecompton:

Estimated monthly discharge of Kansas River at Lawrence, Kans.

[Drainage area 59,841 square miles.]

\begin{tabular}{|c|c|c|c|c|c|c|}
\hline \multirow[b]{2}{*}{ Month. } & \multicolumn{3}{|c|}{ Discharge in second-feet. } & \multirow[b]{2}{*}{$\begin{array}{c}\text { Total in acre- } \\
\text { feet. }\end{array}$} & \multicolumn{2}{|c|}{ Run-off. } \\
\hline & $\begin{array}{l}\text { Maxi- } \\
\text { mum. }\end{array}$ & $\begin{array}{l}\text { Mini- } \\
\text { mum. }\end{array}$ & Mean. & & $\begin{array}{c}\text { Second- } \\
\text { feet per } \\
\text { square } \\
\text { mile. }\end{array}$ & $\begin{array}{l}\text { Depth in } \\
\text { inches. }\end{array}$ \\
\hline $1891 . a$ & & & & & & \\
\hline January $\ldots \ldots$ & 2,123 & 967 & 1,445 & 88,850 & 0.02 & 0.02 \\
\hline February & 7,400 & 1,098 & 3,538 & 196,491 & .06 & .06 \\
\hline March . . . & 11,440 & 1,437 & 6,144 & 377,780 & .10 & .12 \\
\hline April & 12,550 & 5,207 & 8,455 & 503,107 & .14 & .16 \\
\hline May - - & 32,290 & 4,037 & 10,560 & 649,309 & .18 & .21 \\
\hline June . . & 35,750 & 13,120 & 23,102 & $1,374,664$ & .39 & .44 \\
\hline July ... & 19,370 & 9,440 & 13,846 & 851,357 & .23 & .26 \\
\hline August . & 9,440 & 3,673 & 5,444 & 334,739 & .09 & .10 \\
\hline September & 6,490 & 1,255 & 2,768 & 164,707 & .05 & .60 \\
\hline October ... & 10,900 & 2,687 & 5,925 & 364,314 & .10 & .12 \\
\hline
\end{tabular}

aBull. U. S. Geol. Survey No. 140, 1896, pp. 151-152. 
Estimated monthly discharge of Kansas River at Lawrence, Kans.-Continued.

\begin{tabular}{|c|c|c|c|c|c|c|}
\hline \multirow[b]{2}{*}{ Month. } & \multicolumn{3}{|c|}{ Discharge in second-feet. } & \multirow[b]{2}{*}{$\underset{\text { Total in acre- }}{\text { feet. }}$} & \multicolumn{2}{|c|}{ Run-off. } \\
\hline & $\begin{array}{l}\text { Maxi- } \\
\text { mum. }\end{array}$ & $\begin{array}{l}\text { Mini- } \\
\text { mum. }\end{array}$ & Mean. & & $\begin{array}{l}\text { Second- } \\
\text { feet per } \\
\text { square } \\
\text { mile. }\end{array}$ & $\begin{array}{l}\text { Depth in } \\
\text { inohes. }\end{array}$ \\
\hline 1891. & & & & & & \\
\hline November .... & 2,998 & 1,872 & 2,382 & 141,739 & 0.04 & 0.04 \\
\hline December $\ldots . . . . . .$. & 4,803 & 1,870 & 3,129 & 192,395 & .05 & .06 \\
\hline The year - & 35,750 & 967 & 7,228 & $5,289,452$ & .12 & 2.19 \\
\hline $1892 . a$ & & & & & & \\
\hline January .... . . & 2,395 & 1,255 & 1,669 & 102,623 & .03 & .08 \\
\hline February -. & 8,350 & 2,395 & 5,292 & 304,399 & .09 & .09 \\
\hline March ....... & 23,600 & 6,940 & 12,581 & 773,576 & .21 & .24 \\
\hline April ...... & 17,390 & 7,870 & 12,712 & 756,417 & .21 & .23 \\
\hline May ........ & …... & 14,890 & 37,005 & $2,275,348$ & .61 & .70 \\
\hline June ........ & 14,890 & 2,687 & $8, \dot{1} 34$ & 484,007 & .10 & .11 \\
\hline July ..... & 2,687 & 1,437 & 2,059 & 126,603 & .03 & .03 \\
\hline August. . . . . . & 3,673 & 1,255 & 2,010 & 123,590 & .03 & .08 \\
\hline September ..... & 2,998 & 787 & 1,448 & 86,262 & .02 & .02 \\
\hline October . . . . . & 1,643 & 787 & 1,042 & 64,070 & .02 & .02 \\
\hline November..... & 1,872 & 1,098 & 1,487 & 88,483 & .02 & .02 \\
\hline December .... . . & 1,643 & 787 & 1,225 & 75,322 & .02 & .02 \\
\hline The year - & & 787 & 7,222 & $5,260,700$ & .12 & 1.54 \\
\hline $1893 . a$ & & & & & & \\
\hline January . . . . . & 1,437 & 1,098 & 1,278 & 78,581 & .02 & .02 \\
\hline February $\ldots . .$. & 6,490 & 1,255 & 3,650 & 202,711 & .06 & .06 \\
\hline March ....... & 2,123 & 1,098 & 1,339 & 82,332 & .02 & .02 \\
\hline April ..... & 2,998 & 1,255 & 2,011 & 119,663 & .03 & .03 \\
\hline May .......... & 5,207 & 1,643 & 3,209 & 197,314 & .05 & .06 \\
\hline June . . . . . . . & 21,440 & 3,327 & 9,284 & 553,031 & .16 & .18 \\
\hline July . . . . . & 21,440 & 3,327 & 8,474 & 521,046 & .14 & .16 \\
\hline August . . . . . & 15,500 & 1,643 & 5,980 & 368,311 & .10 & .12 \\
\hline September ... & 6,940 & 787 & 2,072 & 123,293 & .03 & .03 \\
\hline October ....... & 10,900 & 1,098 & 3,663 & 225,844 & .06 & .07 \\
\hline November..... & 1,872 & 1,098 & 1,426 & 84,853 & .02 & .02 \\
\hline December ..... & 1,872 & 787 & 1,021 & 62,779 & .02 & .02 \\
\hline The year - & 21,440 & 787 & 3,617 & $2,619,758$ & .06 & .79 \\
\hline $1894 . a$ & & & & & & \\
\hline January $\ldots \ldots$ & 1,643 & 787 & 1,230 & 75,630 & .02 & .02 \\
\hline February $\ldots \ldots \ldots$ & 2,123 & 863 & 1,315 & 78,248 & .02 & .02 \\
\hline
\end{tabular}

$a$ Bull. U. S. Geol. Survey No. 140, 1896, pp. 151-152. 
Estimated monthly discharge of Kansas River at Lawrence, Kans.-Continued.

\begin{tabular}{|c|c|c|c|c|c|c|}
\hline \multirow[b]{2}{*}{ Month. } & \multicolumn{3}{|c|}{ Discharge in second-feet. } & \multirow[b]{2}{*}{$\begin{array}{l}\text { Total in acre- } \\
\text { feet. }\end{array}$} & \multicolumn{2}{|c|}{ Run-off. } \\
\hline & $\begin{array}{l}\text { Maxi- } \\
\text { muny. }\end{array}$ & $\begin{array}{l}\text { Mini- } \\
\text { mum. }\end{array}$ & Mean. & & $\begin{array}{c}\text { Second- } \\
\text { feet per } \\
\text { square } \\
\text { mile. }\end{array}$ & $\begin{array}{l}\text { Depth in } \\
\text { inches. }\end{array}$ \\
\hline 1894. & & & & & & \\
\hline March & 4,035 & 1,255 & 2,134 & 131,215 & 0.04 & 0.04 \\
\hline April & 7,400 & 1,437 & 2,903 & 172,741 & .06 & .05 \\
\hline May . - & 2,123 & 787 & 1,208 & 74,277 & .02 & .02 \\
\hline June _. & 28,990 & 1,255 & 9,044 & 538,155 & .17 & .15 \\
\hline July _... & 11,990 & 1,437 & 4,740 & 291,451 & .09 & .08 \\
\hline August .... & 2,687 & 787 & 1,478 & 90,879 & .03 & .08 \\
\hline September -. & 2,123 & .967 & 1,445 & 85,984 & .02 & .02 \\
\hline October .... & 3,327 & 787 & 1,189 & 73,109 & .02 & .02 \\
\hline November $a$ & - & & 787 & 46,830 & .01 & .01 \\
\hline December $a_{\ldots}$ & $\ldots \ldots$ & $\ldots$ & 550 & 33,818 & .01 & .01 \\
\hline The year & $\ldots .$. & $-\ldots$ & 2,326 & $1,692,337$ & .51 & .04 \\
\hline $1895 . b$ & & & & & & \\
\hline January $a$ & $\cdots$ & $\ldots$ & 500 & 33,818 & .01 & .01 \\
\hline February $a$ & 1,098 & 550 & 680 & 37,765 & .01 & .01 \\
\hline March .... & 1,643 & 967 & 1,364 & 83,869 & .02 & .02 \\
\hline April .. & 1,872 & 967 & 1,372 & 81,640 & .02 & .02 \\
\hline May -. & 1,437 & 787 & 1,074 & 66,038 & .02 & .02 \\
\hline June & 20,050 & 967 & 5,927 & 352,681 & .10 & .11 \\
\hline July .. & 10,370 & 2,395 & 5,666 & 348,389 & .10 & .12 \\
\hline August & 28,190 & 3,163 & 11,318 & 695,917 & .19 & .22 \\
\hline September. . - & 20,050 & 1,255 & 5,088 & 302,757 & .09 & .10 \\
\hline October & 1,346 & 967 & 1,090 & 67,022 & .02 & .02 \\
\hline November... & 1,346 & 863 & 1,044 & 62,122 & .02 & .02 \\
\hline December .... & 1,255 & 863 & 926 & 56,938 & .02 & .02 \\
\hline The year & & $\ldots$ & 3,008 & $2,188,956$ & $i^{05}$ & .69 \\
\hline $1896 . c$ & & & & & & \\
\hline January . . . . . . & 1,540 & 698 & 973 & 59,827 & .016 & .018 \\
\hline February & 1,540 & 1,255 & 1,400 & 80,529 & .023 & .025 \\
\hline March ... & 1,437 & 825 & 1,230 & 75,630 & .021 & .024 \\
\hline April .- & 12,550 & 1,176 & 4,447 & 264,615 & .074 & .082 \\
\hline May - & 34,158 & 4,223 & 13,944 & 857,389 & .230 & .260 \\
\hline June . & 38,583 & 5,546 & 14,$8 ; 9$ & 882,980 & .250 & .280 \\
\hline July .... & 53,308 & 5,546 & 23,408 & $1,439,311$ & .390 & .450 \\
\hline August - & 22,688 & 3,956 & 8,935 & 549,395 & .150 & .170 \\
\hline
\end{tabular}

a Approximate.

$b$ Bull U. S. Geol. Survey No. 140, 1896, pp. 151-159.

$c$ Eighteenth Ann. Rept. U. S. Geol. Survey, pt. 4, 1897, p. 222. 
Estimated monthly discharge of Kansas River at Laurence, Kans.-Continued.

\begin{tabular}{|c|c|c|c|c|c|c|}
\hline \multirow[b]{2}{*}{ Month. } & \multicolumn{3}{|c|}{ Discharge in second-feet. } & \multirow[b]{2}{*}{$\begin{array}{l}\text { Total in acre- } \\
\text { feet. }\end{array}$} & \multicolumn{2}{|c|}{ Run-off. } \\
\hline & $\begin{array}{l}\text { Maxi- } \\
\text { mum. }\end{array}$ & $\begin{array}{l}\text { Mini- } \\
\text { mum. }\end{array}$ & Mean. & & $\begin{array}{l}\text { Second- } \\
\text { feet per } \\
\text { square } \\
\text { mile. }\end{array}$ & $\begin{array}{l}\text { Depth in } \\
\text { inches. }\end{array}$ \\
\hline 1896 & & & & & & \\
\hline September & 12,550 & 2,123 & 4,436 & 263,960 & 0.074 & 0.082 \\
\hline October .... & 7,170 & 1,437 & 1,960 & 120,516 & .033 & .038 \\
\hline November & 11,440 & 2,123 & 3,724 & 221,593 & .062 & .069 \\
\hline December & 3,327 & 2,123 & 2,477 & 152,306 & .041 & .047 \\
\hline The year & 53,308 & 825 & 6,814 & $4,968,051$ & .114 & 1.545 \\
\hline $1897 . a$ & & & & & & \\
\hline January ...... & 2,687 & 967 & 2,137 & 131,399 & .035 & .040 \\
\hline February & 11,440 & 1,643 & 4,720 & 262,136 & .079 & .082 \\
\hline March ... & 5,837 & 2,687 & 3,515 & 216,130 & .059 & .068 \\
\hline April - & 58,000 & 4,035 & 13,782 & 820,085 & .230 & .256 \\
\hline May ... & 14,890 & 3,327 & 5,907 & 363.200 & .099 & .114 \\
\hline June . ....... & 32,290 & 2,395 & 7,321 & 435,630 & .122 & .136 \\
\hline July $\ldots \ldots$ & 39,000 & 2,998 & 10,420 & 640,700 & .174 & .201 \\
\hline August ...... & 5,623 & 897 & 2,904 & 178,560 & .049 & .056 \\
\hline September - - & 1,255 & 715 & 969 & 57,660 & .016 & .018 \\
\hline October ...... & 1,872 & 787 & 1,156 & 71,080 & .019 & .022 \\
\hline November... & 2,687 & 662 & 1,927 & 114,664 & .032 & .036 \\
\hline December ..... & 1,255 & 562 & 775 & 47,652 & .013 & .015 \\
\hline The year & 58,000 & 562 & 4,628 & $3,338,896$ & .077 & 1.044 \\
\hline $1898 . b$ & & & & & & \\
\hline January & 1,255 & 863 & 1,125 & 69,174 & .02 & .02 \\
\hline February .... & 6,490 & 692 & 2,700 & 149,950 & .05 & .05 \\
\hline March ...... & 6,490 & 1,643 & 2,412 & 148,309 & .04 & .04 \\
\hline April & 6,490 & 1,643 & 3,497 & 208,085 & .06 & .07 \\
\hline May ..... & 26,235 & 5,207 & 14,555 & 894,958 & .24 & .28 \\
\hline June . . . . . & 28,990 & 4,803 & 13,684 & 814,253 & .23 & .26 \\
\hline July ......... & 4,803 & 1,255 & 2,570 & 158,024 & .04 & .05 \\
\hline August ....... & 2,395 & 692 & 1,008 & 61,980 & .02 & .02 \\
\hline September .... & 2,687 & 692 & 1,397 & 83,127 . & .02 & .03 \\
\hline October ....... & 1,177 & 592 & 825 & 50,728 & .01 & .02 \\
\hline November. . . . . & 1,032 & 517 & 746 & 44,390 & .01 & .01 \\
\hline December & 4,035 & 507 & 1,448 & 89,035 & .02 & .02 \\
\hline The year. & 28,990 & 507 & 3,831 & $2,772,013$ & .06 & .87 \\
\hline
\end{tabular}




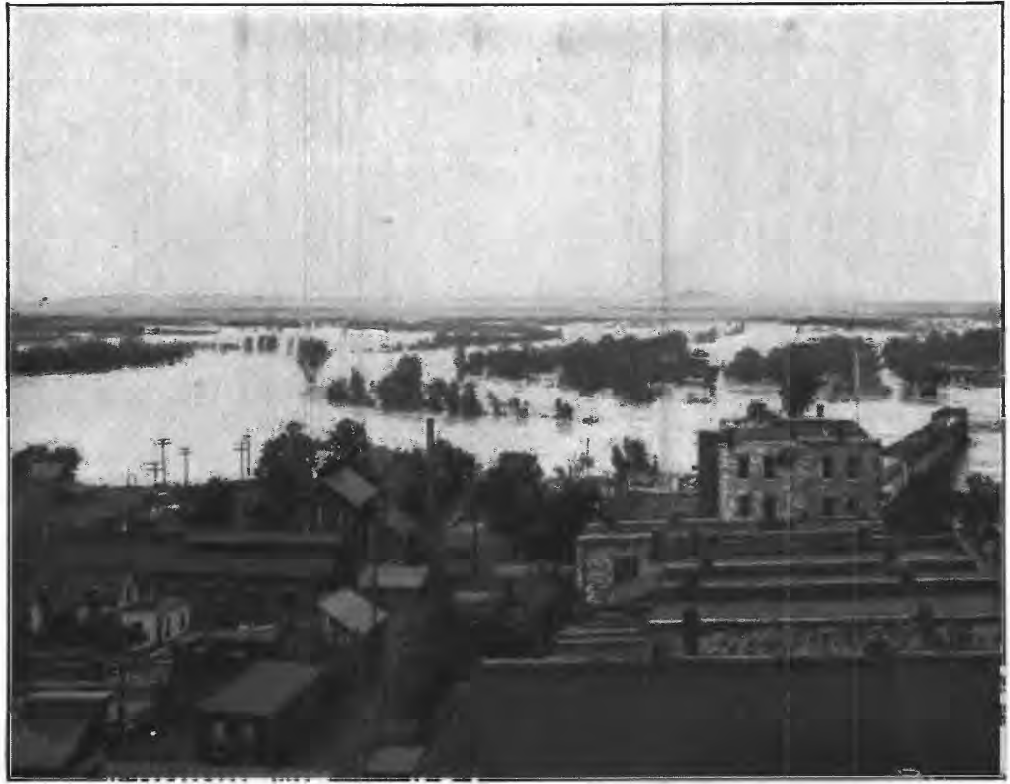

A. VIEW OF THE KANSAS RIVER, DURING FLOOD. TAKEN FROM TOP OF THE NATIONAL BANK, LECOMPTON, KANS.

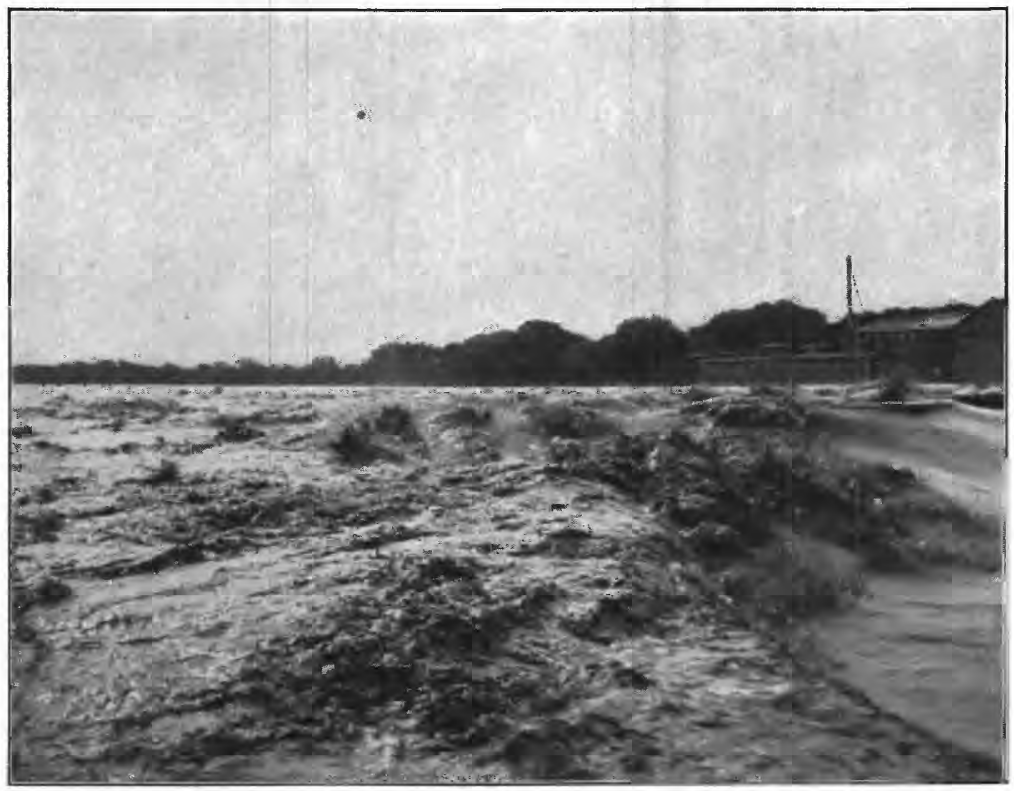

B. "MAD WATERS," LAWRENCE, KANS., DURING FLOOD. 
Estimated monthly discharge of Kansas River at Lecompton, Kans.

[Drainage area, 58,550 square miles.]

\begin{tabular}{|c|c|c|c|c|c|c|}
\hline \multirow[b]{2}{*}{ Month. } & \multicolumn{3}{|c|}{ Discharge in second-feet. } & \multirow[b]{2}{*}{$\begin{array}{c}\text { Total in acre- } \\
\text { feet. }\end{array}$} & \multicolumn{2}{|c|}{ Run-off. } \\
\hline & $\begin{array}{l}\text { Maxi- } \\
\text { mum. }\end{array}$ & $\begin{array}{l}\text { Mini- } \\
\text { mnm. }\end{array}$ & Mean. & & $\begin{array}{c}\text { Second- } \\
\text { feet per } \\
\text { square } \\
\text { mile. }\end{array}$ & $\begin{array}{l}\text { Depth in } \\
\text { inches. }\end{array}$ \\
\hline $1899 . a$ & & & & & & \\
\hline April $b_{-}$ & - & - & 2,693 & 160,245 & 0.05 & 0.06 \\
\hline May ... & 16,800 & 2,380 & 5,455 & 335,415 & .09 & .10 \\
\hline June - - & 24,800 & 3,600 & 10,609 & 631,279 & .18 & .20 \\
\hline July $\ldots . .$. & 30,250 & 3,865 & 9,7771 & 600,795 & .17 & .20 \\
\hline August ... & 8,335 & 2,720 & 4,855 & 298,522 & .08 & .09 \\
\hline September ... & 2,580 & 1,850 & 2,154 & 128,172 & .04 & .05 \\
\hline October & 3,150 & 1,750 & 1,938 & 119,163 & .03 & .03 \\
\hline November.... . & 3,000 & 1,950 & 2,236 & 133,051 & .04 & .05 \\
\hline December ... . & 3,150 & 1,850 & 2,379 & 146,279 & .04 & .05 \\
\hline $1900 . c$ & & & & & & \\
\hline January ........ & 3,481 & 2,960 & 3,421 & 210,349 & .06 & .07 \\
\hline February - & 3,613 & 2,830 & 3,234 & 179,607 & .06 & .06 \\
\hline March .... & 24,898 & 3,220 & 7,807 & 480,034 & .13 & .15 \\
\hline April .. & 9,520 & 4,150 & 5,896 & 350,836 & .10 & .11 \\
\hline May ........ & 12,220 & 6,045 & 7,965 & 489,749 & .14 & .16 \\
\hline June . . . . . . & 9,200 & 3,880 & 6,303 & 375,055 & .11 & .12 \\
\hline July ...... & 18,722 & 3,613 & 7,340 & 451,319 & .13 & .15 \\
\hline August ...... & 5,095 & 3,481 & 4,455 & 273,927 & .08 & .09 \\
\hline September ... & 15,635 & 3,880 & 6,947 & 413,375 & .12 & .13 \\
\hline October & 7,810 & 3,746 & 4,913 & 302,089 & .08 & .09 \\
\hline November.... . & 8,110 & 3,613 & 4,622 & 275,028 & .08 & .09 \\
\hline December ..... & 3,613 & 3,350 & 3,418 & 210,165 & .06 &. .07 \\
\hline The year - & 24,898 & 2,830 & 5,527 & $4,011,533$ & .10 & 1.29 \\
\hline $1901 . d$ & & & & & & \\
\hline January ...... & 2,375 & 1,210 & 1,772 & 108,956 & .03 & .03 \\
\hline February ... & 8,820 & 1,210 & 3,142 & 174,497 & .05 & .05 \\
\hline March ........ & 11,110 & 4,465 & 6,353 & 390,631 & .11 & .13 \\
\hline April $\ldots$ & 25,000 & 4,332 & 12,844 & 764,271 & .22 & .25 \\
\hline May ...... & 7,005 & 2,625 & 4,767 & 293,111 & .08 & .09 \\
\hline June ...... & 4,465 & 2,375 & 3,231 & 192,258 & .06 & .07 \\
\hline July & 2,625 & . 275 & 1,123 & 69,051 & .02 & .02 \\
\hline August & 4,465 & 275 & $2 ; 173$ & 133,613 & .04 & .05 \\
\hline
\end{tabular}

a Twenty-first Ann. Rept. U. S. Geol. Survey, pt. 4, 1901, p. 228. $b$ For entire month, based on gage heights of April 16 to 30 .

c Twenty-second Ann. Rept. U. S. Geol Survey, pt. 4, 1902, p. 338.

$a$ Water-Sup. and Irr. Paper No. 75, U. S. Geol. Survey, 1908, p. 144 
Estimated monthly discharge of Kansas River at Lecompton, Kans.—Continued.

\begin{tabular}{|c|c|c|c|c|c|c|}
\hline \multirow[b]{2}{*}{ Month. } & \multicolumn{3}{|c|}{ Discharge in second-feet. } & \multirow[b]{2}{*}{$\begin{array}{l}\text { Total in acre- } \\
\text { feet. }\end{array}$} & \multicolumn{2}{|c|}{ Run-off. } \\
\hline & $\begin{array}{l}\text { Maxi- } \\
\text { mum. }\end{array}$ & $\begin{array}{l}\text { Mini- } \\
\text { mum. }\end{array}$ & Mean. & & $\begin{array}{c}\text { Second- } \\
\text { feet per } \\
\text { square } \\
\text { mile. }\end{array}$ & $\begin{array}{l}\text { Depth in } \\
\text { inches. }\end{array}$ \\
\hline 1901. & & & & & & \\
\hline September ... & 6,710 & 2,375 & 4,367 & 259,855 & 0.07 & 0.08 \\
\hline October ..... & 5,000 & 445 & 2,270 & 139,577 & .04 & .05 \\
\hline November - & 1,885 & 275 & 1,222 & 72,714 & .02 & .02 \\
\hline December _ _ _ & 1,000 & 625 & 805 & 49,498 & .01 & .01 \\
\hline The year & 25,000 & 275 & 3,672 & $2,648,032$ & .06 & .85 \\
\hline $1902 . a$ & & & & & & \\
\hline January . . . . . & 1,000 & 445 & 767 & 47,161 & .01 & .01 \\
\hline February ... & 625 & 275 & 492 & 27,324 & .01 & .01 \\
\hline March ..... & 3,675 & 100 & 2,460 & 151,259 & .04 & .05 \\
\hline April ..... & 3,415 & 2,250 & 2,653 & 157,864 & .05 & .06 \\
\hline May _...... & 23,075 & 2,125 & 8,435 & 518,648 & .14 & .16 \\
\hline June ...... . . & 28,500 & 11,110 & 17,131 & $1,019,365$ & .29 & .32 \\
\hline July . . . . . . & 81,400 & 11,450 & 38,291 & $2,354,422$ & .65 & .75 \\
\hline August .... & 40,812 & 6,415 & 11,941 & 734,223 & .20 & .23 \\
\hline September - & 53,050 & 5,270 & 14,990 & 891,977 & .26 & .29 \\
\hline Oetober & 42,112 & 9,130 & 17,734 & $1,090,421$ & .30 & .35 \\
\hline November & 13,320 & 9,450 & 10,830 & 614,430 & .18 & .20 \\
\hline December .. - & 15,900 & 9,130 & 11,785 & 724,631 & .20 & .23 \\
\hline The year - & 81,400 & 100 & 11,459 & $8,361,725$ & .20 & 2.66 \\
\hline 1903 & & & & & & \\
\hline January ..... & 14,170 & 11,100 & 12,613 & 775,542 & .22 & .25 \\
\hline February & 13,830 & 9,130 & 11,035 & 612,883 & .19 & .20 \\
\hline March & 25,000 & 9,610 & 16,156 & 993,394 & .28 & .32 \\
\hline April & 10,265 & 5,275 & 7,182 & 427,359 & .12 & .13 \\
\hline May ..... & 221,000 & 5,000 & 45,018 & $2,768,049$ & .77 & .89 \\
\hline June . . . . . . & 205,500 & 11,000 & 65,268 & $3,883,715$ & 1.11 & 1.34 \\
\hline July .... & 20,900 & 11,750 & 14,085 & 866,052 & .24 & .28 \\
\hline August .... & 58,500 & 11,187 & 27,568 & $1,695,090$ & .47 & .54 \\
\hline September ... & 18,325 & 2,635 & 8,631 & 513,580 & .15 & .17 \\
\hline October & 5,000 & 2,375 & 3,698 & 227,381 & .063 & .073 \\
\hline November . . . . & 12,500 & 5,692 & 10,182 & 605,871 & .17 & .19 \\
\hline December . . . . . . . & 8,205 & 5,000 & 6,472 & 397,948 & .11 & .13 \\
\hline The year. & 221,000 & 2,375 & 18,992 & $13,766,834$ & .324 & 4.513 \\
\hline
\end{tabular}

$a$ Water-Sup. and Irr. Paper No. 84, U. S. Geol. Survey, 1903, p. 97. 
The hydrographs of this river at this station (see Pl. XII, $A$, p. 52) show very clearly how the discharge varies throughout the year. The minimum flow occurs in December or January, during very cold weather, and has been less than 600 second-feet. The maximum flow oceurs, as a rule, some time between May 1 and July 31, and hence is due to rain and not melting snow. The monthly run-off per square mile prior to May, 1903, varies from 0.01 to 0.60 second-foot and the yearly run-off per square mile from 0.04 to 0.20 second-foot. In June, 1903 , during the flood, however, the run-off per square mile was 1.11 second-feet, and the run-off for the year was 0.324 second-foot. The maximum monthly run-off is 129 times the minimum monthly run-off.

BLUE RIVER NEAR MANHATTAN, KANS.

The station on Blue River is at a highway bridge 4 miles north of Manhattan. It was established April 12, 1895, and has been in operation since that date. The channel is straight for several hundred feet above and below the bridge and is 225 feet wide at ordinary stage, withont piers. The bed is mainly clay and changes very little. The gage is a vertical timber, marked to feet and tenths of a foot. The left bank is subject to overflow. During the flood of May and June, 1903, the water was 3 feet deep on the bridge, and the drift and a considerable portion of the flood, estimated at 60 per cent of the flow, passed around the bridge.

The following table gives the run-off data obtained at this station:

Estimated monthly discharge of Blue River near Manhattan, Kans.

[Drainage area, 9,490 square miles.]

\begin{tabular}{|c|c|c|c|c|c|c|}
\hline \multirow[b]{2}{*}{ Month. } & \multicolumn{3}{|c|}{ Discharge in second-feet. } & \multirow[b]{2}{*}{$\begin{array}{c}\text { Total in acre- } \\
\text { feet. }\end{array}$} & \multicolumn{2}{|c|}{ Run-off. } \\
\hline & $\begin{array}{l}\text { Maxi- } \\
\text { mum. }\end{array}$ & $\begin{array}{l}\text { Mini- } \\
\text { mum. }\end{array}$ & Mean. & & $\begin{array}{c}\text { Second- } \\
\text { feet per } \\
\text { square } \\
\text { mile. }\end{array}$ & $\begin{array}{l}\text { Depth in } \\
\text { inches. }\end{array}$ \\
\hline $1895 . a$ & & & & & & \\
\hline April 14 to 30 & 605 & 502 & 548 & 18,479 & 0.06 & 0.04 \\
\hline May ......... & 986 & 431 & 552 & 33,941 & .06 & .07 \\
\hline June . . . . . & 7,500 & 552 & 1,604 & 95,444 & .17 & .19 \\
\hline July .. & 2,301 & 527 & 756 & 46,485 & .09 & .10 \\
\hline August & 9,900 & $478^{\circ}$ & 2,036 & 125,190 & .21 & .24 \\
\hline September - & 8,550 & 552 & 1,207 & 71,822 & .13 & .15 \\
\hline October & 552 & 385 & 495 & 30,436 & .05 & .06 \\
\hline November & 605 & 385 & 531 & 31,597 & .06 & .07 \\
\hline December $\ldots \ldots$ & 605 & 502 & 577 & 35,478 & .06 & .07 \\
\hline
\end{tabular}

a Eighteenth Ann. Rept. U. S. Geol. Survey, pt. 4, 1897, p. 218. 
Estimated monthly discharge of Blue River near Manhattan, Kans.-Continued.

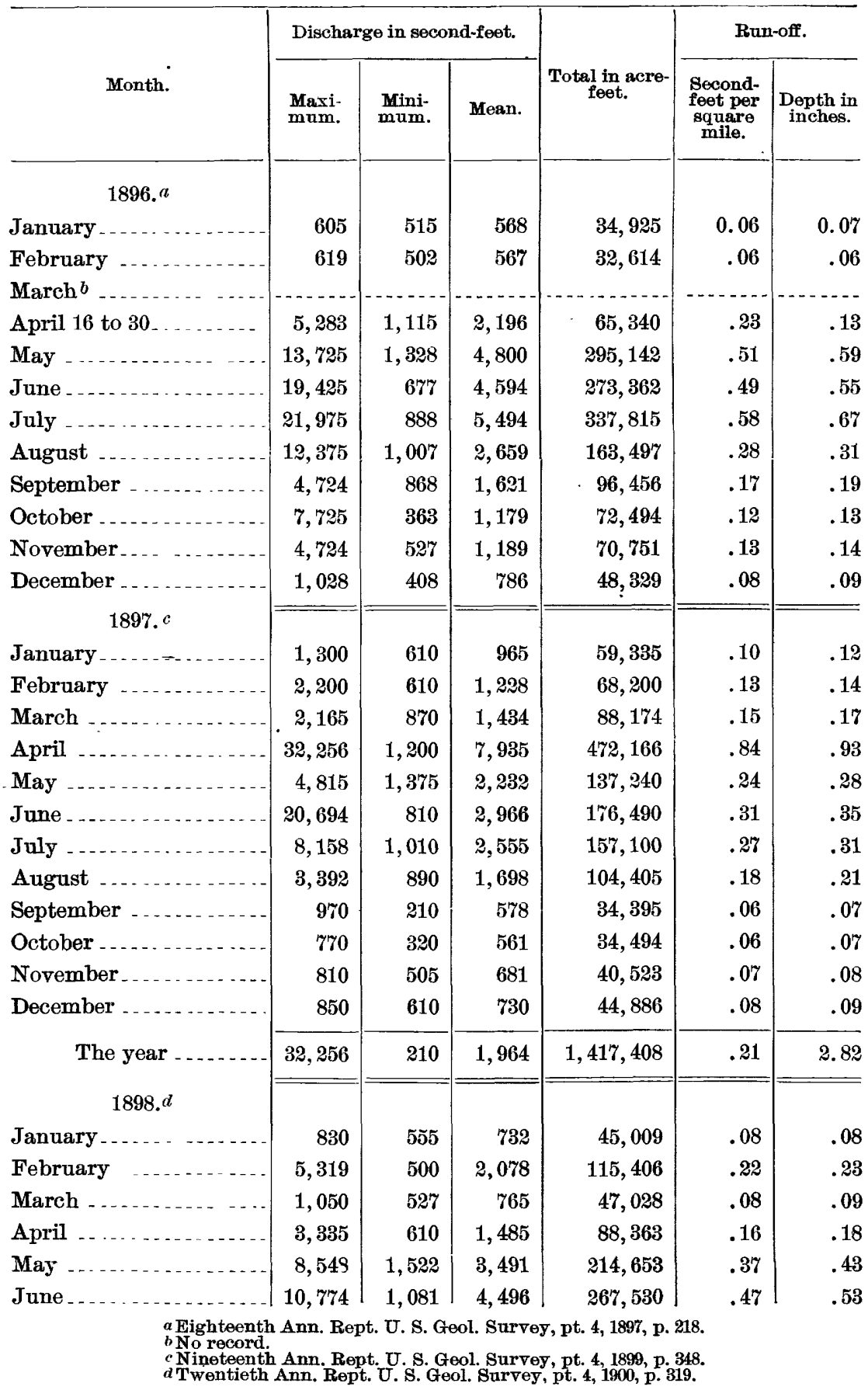




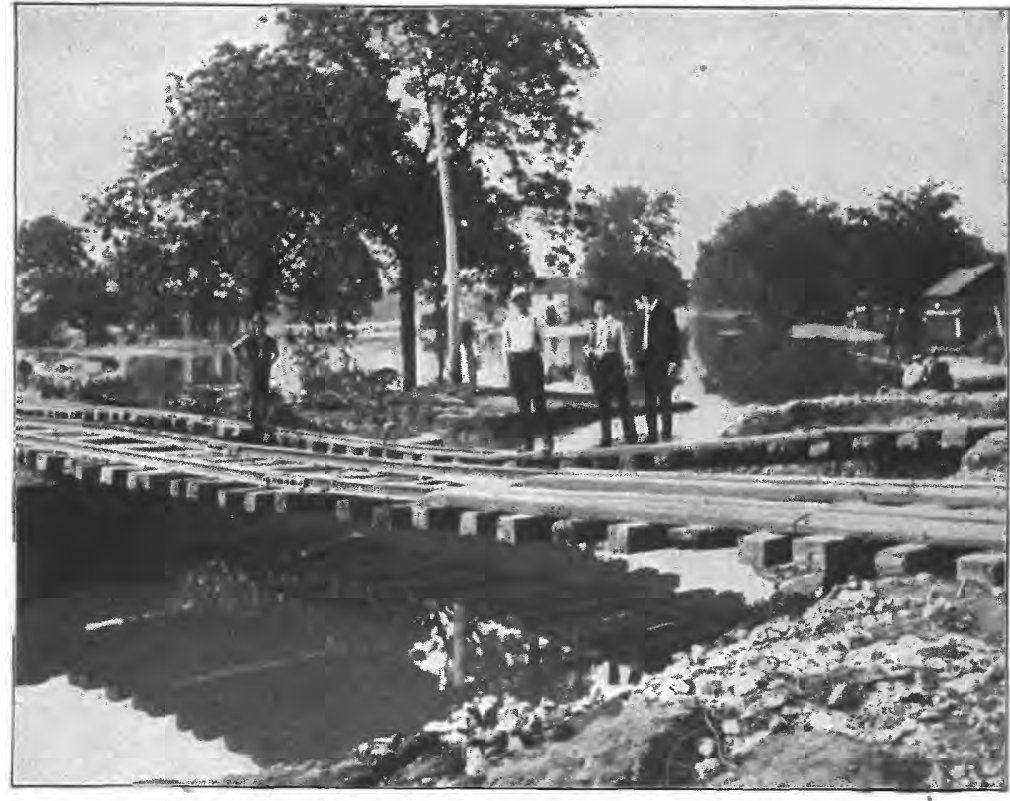

A. UNDERMINED SECTION OF RAILROAD NEAR LAWRENCE, KANS.

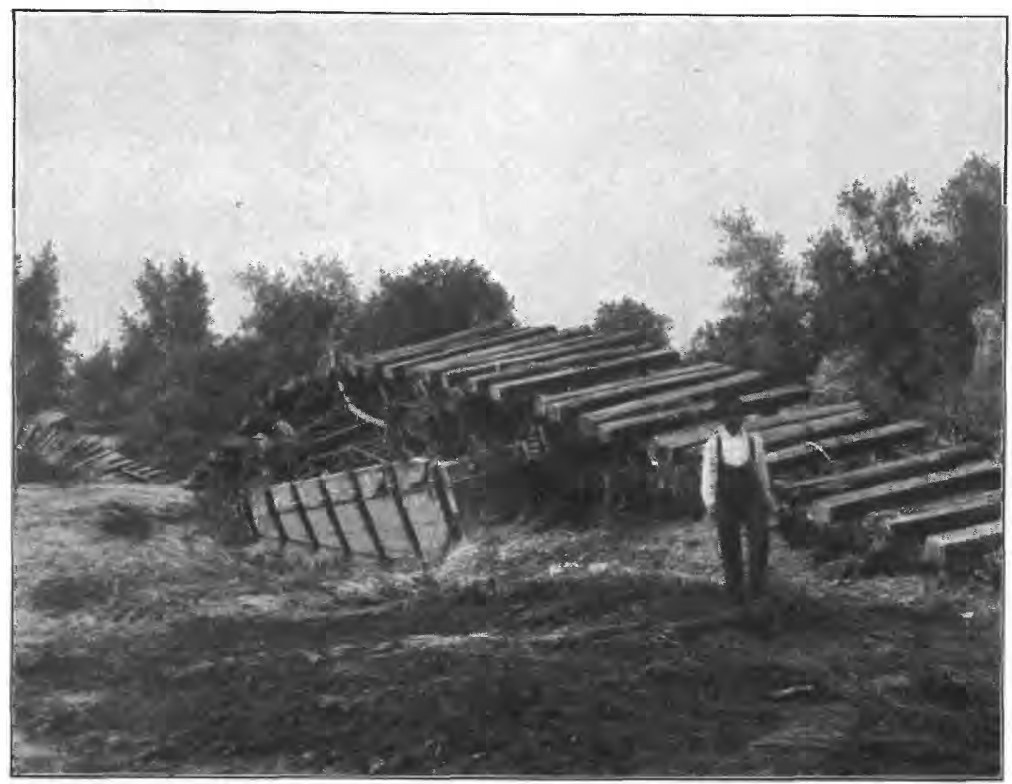

B. RAILROAD TRACK ON TOP OF COAL CAR NEAR LAWRENCE, KANS. 
Estimated monthly discharge of Blue River near Manhattan, Kans.-Continued.

\begin{tabular}{|c|c|c|c|c|c|c|}
\hline \multirow[b]{2}{*}{ Month. } & \multicolumn{3}{|c|}{ Discharge in second-feet. } & \multirow[b]{2}{*}{$\begin{array}{l}\text { Total in acre- } \\
\text { feet. }\end{array}$} & \multicolumn{2}{|c|}{ Run-off. } \\
\hline & $\begin{array}{l}\text { Maxi- } \\
\text { mum. }\end{array}$ & $\begin{array}{l}\text { Mini- } \\
\text { mum. }\end{array}$ & Mean. & & $\begin{array}{l}\text { Second- } \\
\text { feet per } \\
\text { square } \\
\text { mile. }\end{array}$ & $\begin{array}{l}\text { Depth in } \\
\text { inches. }\end{array}$ \\
\hline 1898. & & & & & & \\
\hline July .......... & 1,333 & 500 & 740 & 45,501 & 0.08 & 0.09 \\
\hline August .. . & 610 & 230 & 454 & 27,916 & .05 & .06 \\
\hline September ... & 665 & 230 & 377 & 22,433 & .04 & .04 \\
\hline October & 637 & 207 & 360 & 22,136 & .04 & .04 \\
\hline November.... . & 555 & 342 & 443 & 26,361 & .05 & .06 \\
\hline December . . . . & 775 & 432 & 615 & 37,815 & .06 & .07 \\
\hline The year & 10,774 & 207 & 1,336 & 960,151 & .14 & 1.90 \\
\hline $1899 .^{a}$ & & & - & & & \\
\hline January . . . . . . & 910 & 680 & 721 & 44,333 & .08 & .09 \\
\hline February & 1,080 & 770 & 876 & 48,651 & .09 & .09 \\
\hline March . . . . & 7,240 & 792 & 1,845 & 113,445 & .19 & .22 \\
\hline April ...... & 1,325 & 702 & 944 & 56,172 & .10 & .11 \\
\hline May ..... & 29,693 & 635 & 4,081 & 250,931 & .43 & .49 \\
\hline June & 30,080 & 1,325 & 4,767 & 283,656 & .50 & .56 \\
\hline July .... & $10,3 \pi 1$ & 885 & 2,699 & 165,955 & .28 & $.32^{\circ}$ \\
\hline August ... & 6,367 & 305 & 1,532 & 94,199 & .16 & .18 \\
\hline September & 635 & 400 & 498 & 29,633 & .05 & .06 \\
\hline October & 2,212 & 287 & 597 & 36,708 & .06 & .07 \\
\hline November ... & 612 & 460 & 536 & 31,894 & .06 & .07 \\
\hline December & 747 & 380 & 524 & 32,220 & .06 & .07 \\
\hline The year & 30,030 & 287 & 1,685 & $1,187,797$ & .17 & 2.33 \\
\hline $1900 . b$ & & & & & & \\
\hline January . . . . . . & 960 & 270 & 619 & 38,061 & .07 & .08 \\
\hline February & 815 & 460 & 585 & 32,489 & .06 & .06 \\
\hline March . . . . . . & 5,705 & 657 & 1,388 & 85,345 & .15 & .17 \\
\hline April & 4,457 & 522 & 1,392 & 82,830 & .15 & .17 \\
\hline May .... & 8,240 & 1,160 & 2,736 & 168,230 & .29 & .33 \\
\hline June.... & 1,690 & 590 & 967 & 57,540 & .10 & .11 \\
\hline July ..... & 23,280 & 400 & 2,580 & 158,638 & .27 & .31 \\
\hline August .... & 2,927 & 500 & 973 & 59,827 & .10 & .12 \\
\hline September - & 4,410 & 522 & 1,812 & 107,821 & .19 & .21 \\
\hline October & $1,110^{-}$ & 545 & 731 & 44,947 & .08 & .09 \\
\hline
\end{tabular}

a Twenty-first Ann. Rept. U. S. Geol. Survey, pt. 4, 1901, p. 227.

$b$ Twenty-second Ann. Rept. U. S. Geol. Survey, pt. 4, 1902, p. 3337. 
Estimated monthly discharge of Blue River near Manhattan, Kans.-Continued.

\begin{tabular}{|c|c|c|c|c|c|c|}
\hline \multirow[b]{2}{*}{ Month. } & \multicolumn{3}{|c|}{ Discharge in second-feet. } & \multirow[b]{2}{*}{$\begin{array}{l}\text { Total in acre- } \\
\text { feet. }\end{array}$} & \multicolumn{2}{|c|}{ Run-off. } \\
\hline & $\begin{array}{l}\text { Maxi- } \\
\text { mum. }\end{array}$ & $\begin{array}{l}\text { Mini- } \\
\text { mum. }\end{array}$ & Mean. & & $\begin{array}{c}\text { Second- } \\
\text { feet per } \\
\text { square } \\
\text { mile. }\end{array}$ & $\begin{array}{l}\text { Depth in } \\
\text { inches. }\end{array}$ \\
\hline 1900. & & & & & & \\
\hline November & 1,500 & 590 & 727 & 43,259 & 0.08 & 0.09 \\
\hline December . . . & 635 & 460 & 589 & 36,216 & .06 & .07 \\
\hline The year - & 23,280 & 270 & 1,258 & 915,203 & .13 & 1.81 \\
\hline 1901.“ & & & & & & \\
\hline January ..... & 815 & 522 & 682 & 41,935 & .07 & .08 \\
\hline February & 4,082 & 635 & 1,471 & 81,695 & .16 & .17 \\
\hline March _... & 3,013 & $\cdot 7 \% 0$ & 1,129 & 69,420 & .12 & .14 \\
\hline April .... & 13,155 & 1,010 & 2,146 & 127,696 & .23 & .26 \\
\hline May - - & 2,325 & 725 & 1,152 & 70,834 & .12 & .14 \\
\hline June ... & 1,500 & 460 & 828 & 49,269 & .09 & .10 \\
\hline July ...... & 770 & 305 & 473 & 29,084 & .05 & .06 \\
\hline August .... & 2,800 & 380 & r75 & 47,653 & .08 & .09 \\
\hline September ... & 1,010 & 305 & 511 & 30,407 & .05 & .06 \\
\hline October .... & 590 & 380 & 470 & 28,899 & .05 & .06 \\
\hline November... & 1,325 & 460 & 590 & 35,107 & .06 & .07 \\
\hline December & 680 & 380 & 498 & 30,621 & .05 & .06 \\
\hline The year - & 13,155 & 305 & 894 & 642,620 & .09 & 1.29 \\
\hline $1902 . b$ & & & & & & \\
\hline January ... . - & 560 & 408 & 461 & 28,346 & .05 & .06 \\
\hline February -. - & 910 & 408 & 619 & 34,378 & .07 & .07 \\
\hline March ..... & 910 & 480 & 618 & 37,983 & .07 & .08 \\
\hline April ...... & 560 & $40 \dot{8}$ & 483 & 28,740 & .05 & .06 \\
\hline May ........ & 17,510 & 408 & 2,157 & 132,629 & .23 & .27 \\
\hline June........ & 17,510 & 910 & 6,298 & 374,757 & .66 & .74 \\
\hline July _....... & 43,430 & 4,540 & 16,866 & $1,03 \%, 050$ & 1.78 & 2.05 \\
\hline August ... . . & 27,686 & 1,790 & 4,329 & 266,180 & .46 & .53 \\
\hline September .... & 29,990 & 1,460 & 5,011 & 298,175 & .53 & .59 \\
\hline October ........ & 20,006 & 1,790 & 5,071 & 311,804 & .53 & .61 \\
\hline November. . . . . & 4,740 & 1,526 & 1,945 & 115,735 & .20 & .22 \\
\hline December ............ & 3,136 & 1,066 & 1,897 & 116,642 & .20 & .23 \\
\hline The year & 43,430 & 408 & 3,813 & $2,782,419$ & .40 & 5.51 \\
\hline
\end{tabular}


Estimated monthly discharge of Blue River near Manhattan, Kans.-Cont.nued.

\begin{tabular}{|c|c|c|c|c|c|c|}
\hline \multirow[b]{2}{*}{ Month. } & \multicolumn{3}{|c|}{ Discharge in second-feet. } & \multirow[b]{2}{*}{$\begin{array}{c}\text { Total in acre- } \\
\text { feet. }\end{array}$} & \multicolumn{2}{|c|}{ Run-off. } \\
\hline & $\begin{array}{l}\text { Maxi- } \\
\text { mum. }\end{array}$ & $\begin{array}{l}\text { Mini- } \\
\text { mum. }\end{array}$ & Mean. & & $\begin{array}{l}\text { Second- } \\
\text { feet per } \\
\text { square } \\
\text { mile. }\end{array}$ & $\begin{array}{l}\text { Depth in } \\
\text { inches. }\end{array}$ \\
\hline 1903. & & & & & & \\
\hline January _.... & 2,710 & 875 & 1,542 & 94,814 & 0.16 & 0.18 \\
\hline February $\ldots .$. & 11,460 & 785 & 2,373 & 131,790 & .25 & .26 \\
\hline March ..... & 9,815 & 1,220 & 4,929 & $303,07 \%$ & .52 & .60 \\
\hline April & 1,560 & 785 & 1,046 & 62,241 & .11 & .12 \\
\hline May ......... & 68,770 & 1,220 & 19,092 & $1,173,920$ & 2.01 & 2.42 \\
\hline June.... & 66,170 & 3,430 & 16,427 & 977,474 & 1.73 & 1.98 \\
\hline July -.. & 4,580 & 1,700 & 2,644 & 162,573 & .28 & .32 \\
\hline August. . . . . . & 34,710 & 1,840 & 9,626 & 591,880 & 1.01 & 1.16 \\
\hline September ...... & 6,235 & 1,155 & 2,576 & - 153,282 & .27 & .30 \\
\hline October .... & 2,710 & 925 & 1,337 & 82,209 & .14 & .16 \\
\hline November.. & 5,860 & 1,035 & 1,849 & 50,519 & .19 & .21 \\
\hline December ....... & 2,290 & 785 & 1,044 & 64,193 & .11 & .18 \\
\hline The year - & 68,770 & 785 & 5,374 & $3,847,967$ & .565 & 7.78 \\
\hline
\end{tabular}

The hydrograph of this stream at the gaging station is shown on Pl. XII, $B$, p. 52. It resembles to some extent that for the station on Kansas River at Lawrence, the minimum discharge occurring in December or January, and the maximum some time between April 1 and August 31. The monthly run-off per square mile prior to 1903 varied from 0.04 to 1.78 second-feet, and the yearly run-off per square mile from 0.09 to 0.40 second-foot. In May, 1903, the run-off per square mile was 2.01 second-feet, and the run-off per square mile for the year 1903 was 0.565 second-foot. The maximum monthly discharge is 53 times the minimum monthly discharge.

This stream is seen to have a more steady flow than Kansas River. This is because the Blue has a larger rainfall over its whole drainage area than the Kansas. In the Blue River watershed the mean annual rainfall is about 30 inches, and in the Kansas River basin it varies from 35 inches in the eastern part to 12 inches in the western part.

REPUBLIOAN RIVER AT JUNCTION, KANS.

There are four stations on Republican River. One is at Junction, Kans., one at Superior, and two at Benkelman, Nebr. The station at Junction, Kans., is at Washington street highway bridge. It was established April 26, 1895, and has been maintained continuously since that time. This bridge is at a large bend in the stream. At low stages the channel is straight for 200 feet above and below the 
station. The width is about 375 feet, broken by three piers. The bed is sandy and somewhat changeable. The velocity is rapid. The gage is a vertical timber marked to feet and tenths of a foot. During the flood of May and June a portion of the flow, estimated at 50 per cent of the total, passed around the left abutment and scoured out a channel about 4 feet deep and 200 to 300 feet in width.

The run-off results obtained at tlis station are given in the following table:

Estimated monthly discharge of Republican River at Junction, Kans.

[Drainage area, 25,837 square miles.]

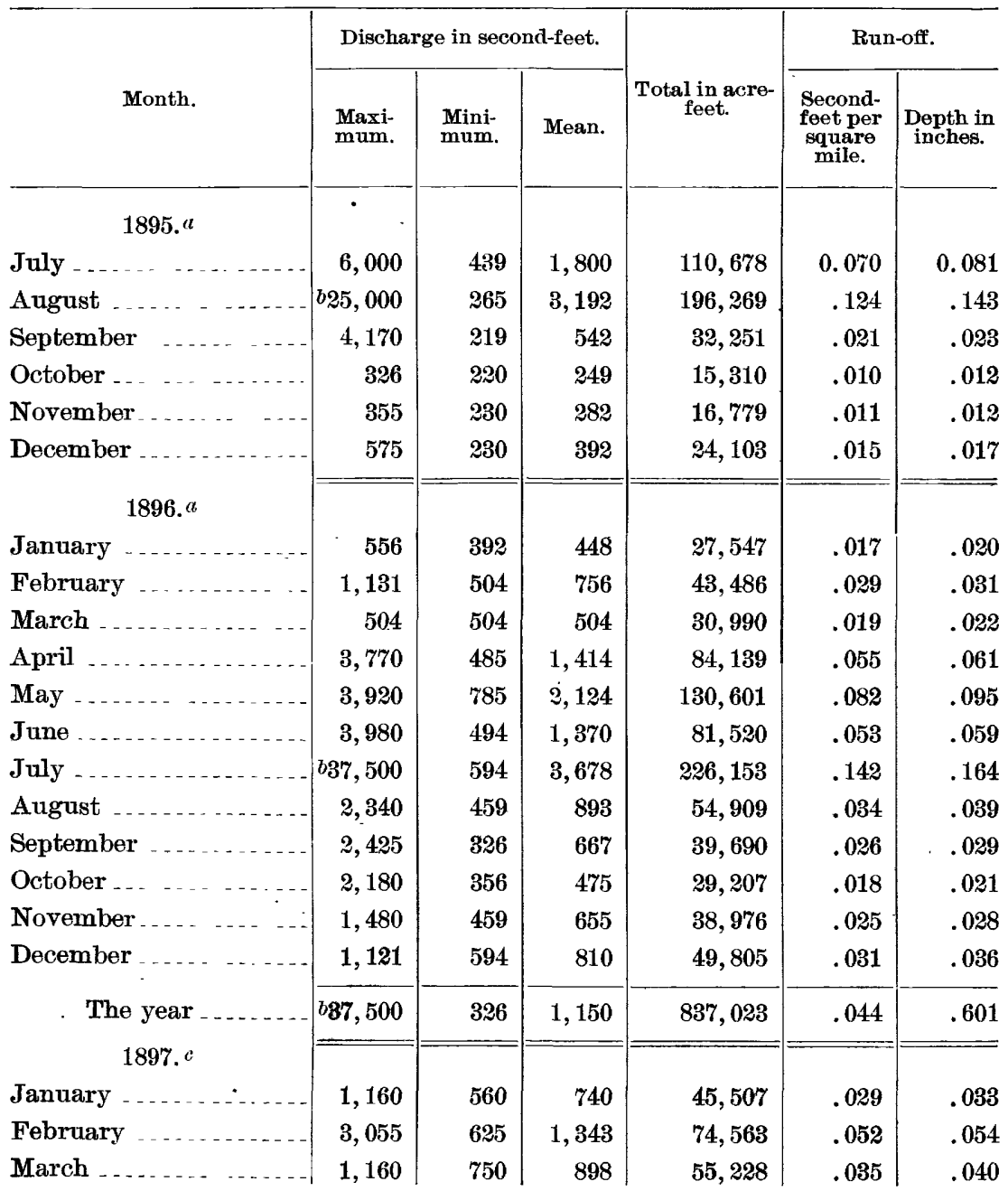

$a$ Eighteenth Ann. Rept. U. S. Geol. Survey, pt. 4, 1897, p. 205. $b$ Estimated

$c$ Nineteenth Ann. Rept. U. S. Geol. Survey, pt. 4, 1899, p. 340. 


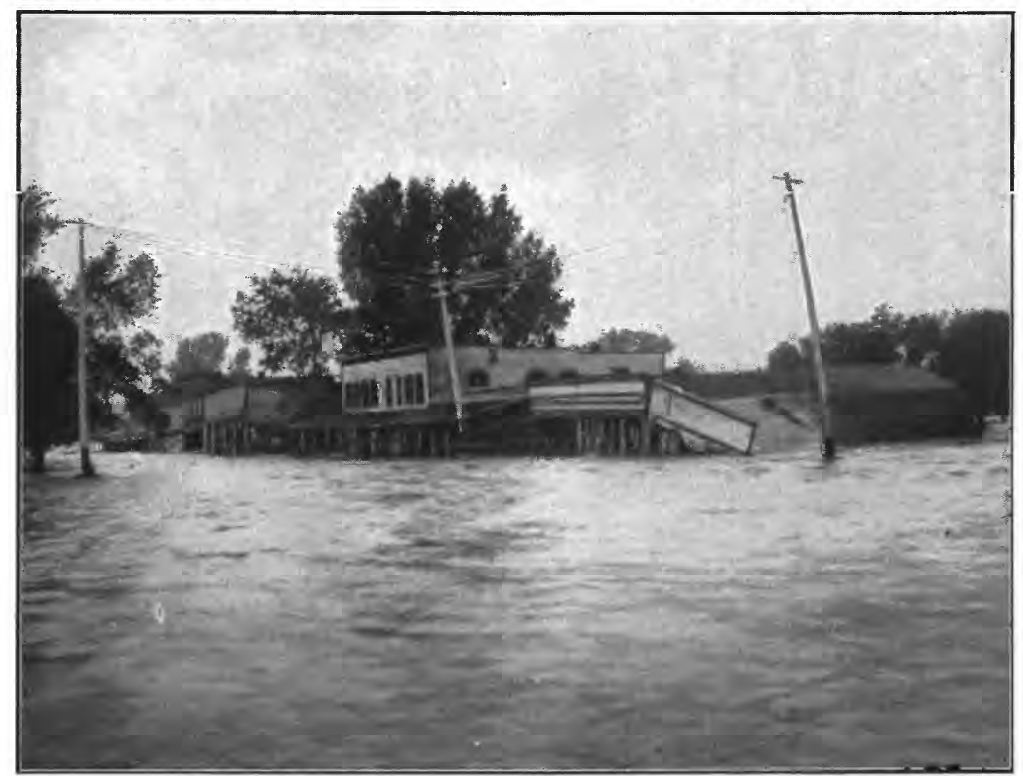

A. BRIDGE STREET, NORTH LAWRENCE, KANS, DURING THE FLOOD.

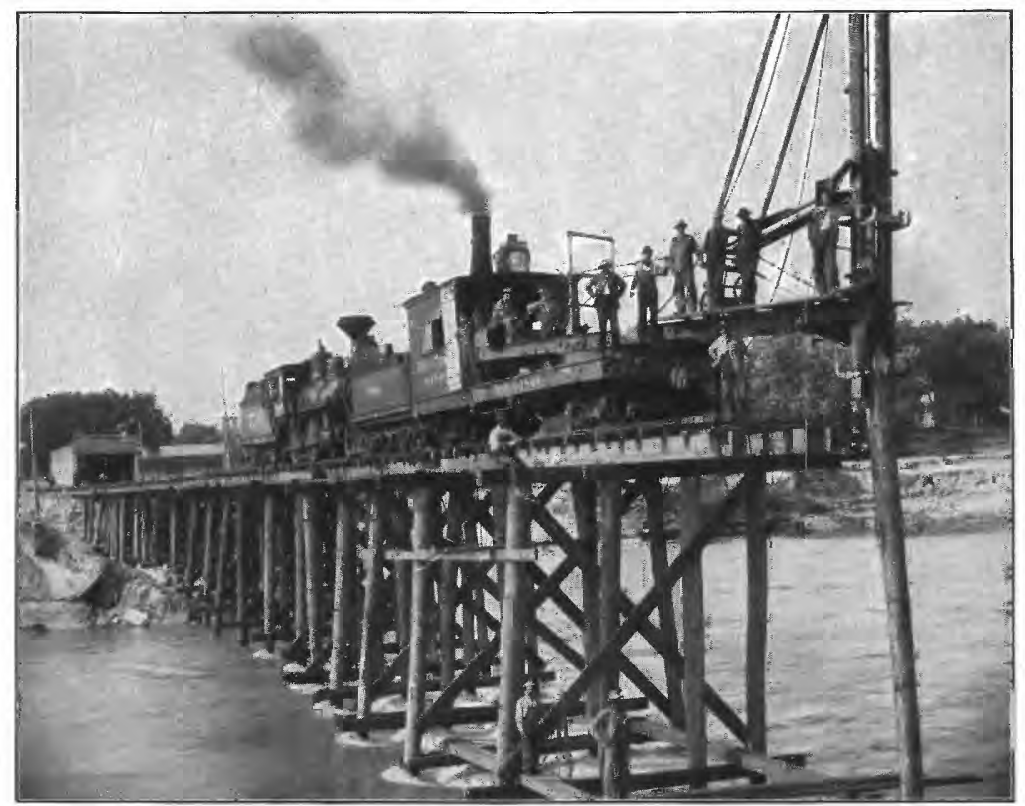

B. PILE DRIVER CONSTRUCTING TEMPORARY BRIDGE OVER NEW NORTH CHANNEL, LAWRENCE, KANS. 
Estimated monthly discharge of Republican River at Junction, Kans.-Continued.

\begin{tabular}{|c|c|c|c|c|c|c|}
\hline \multirow[b]{2}{*}{ Month. } & \multicolumn{3}{|c|}{ Discharge in second-feet. } & \multirow[b]{2}{*}{$\begin{array}{l}\text { Total in acre- } \\
\text { feet. }\end{array}$} & \multicolumn{2}{|c|}{ Run-off. } \\
\hline & $\begin{array}{l}\text { Maxi- } \\
\text { mum. }\end{array}$ & $\begin{array}{l}\text { Mini- } \\
\text { mum. }\end{array}$ & Mean. & & $\begin{array}{c}\text { Second- } \\
\text { feet per } \\
\text { square } \\
\text { mile. }\end{array}$ & $\begin{array}{l}\text { Depth in } \\
\text { inches. }\end{array}$ \\
\hline 1897. & & & & & & \\
\hline April ......... & 8,250 & 1,000 & 2,032 & 120,895 & $0.078^{\circ}$ & 0.087 \\
\hline May $\ldots . . . . .$. & 2,550 & 325 & 833 & 51,213 & .032 & .037 \\
\hline June . . . . . . & 6,053 & 290 & 1,592 & 94,713 & .062 & .068 \\
\hline July $\ldots \ldots$ & 6,360 & 440 & 1,824 & 112,147 & .071 & .082 \\
\hline August ..... & 2,210 & 254 & 619 & 38,042 & .024 & .028 \\
\hline September . . & 537 & 125 & 204 & 12,156 & .008 & .009 \\
\hline October .... & 415 & 85 & 205 & 12,605 & .008 & .009 \\
\hline November. . & 1,120 & 290 & 632 & $37,5 \% 7$ & .024 & .027 \\
\hline December ... & 930 & 290 & 668 & 41,070 & .026 & .030 \\
\hline The year & 6,360 & 85 & 966 & 695,716 & .087 & .504 \\
\hline $1898 . a$ & & & & & & \\
\hline January ...... & 900 & 475 & 732 & 45,009 & .03 & .03 \\
\hline February .... & 1,895 & 645 & 1,034 & 57,425 & .04 & .04 \\
\hline March . . . . . & 825 & 475 & 656 & 40,336 & .03 & .03 \\
\hline April ......... & 1,310 & 590 & 804 & 47,841 & .03 & .03 \\
\hline May ......... & 7,175 & 862 & 2,126 & 130,723 & .08 & .09 \\
\hline June........ & 6,165 & 700 & 2,125 & 126,446 & .08 & .09 \\
\hline July .... & 645 & 210 & 429 & 26,378 & .02 & .02 \\
\hline August & 252 & 69 & 142 & 8,732 & .01 & .01 \\
\hline September .... & 325 & 69 & 155 & 9,223 & .01 & .01 \\
\hline October ......... & 252 & 124 & 190 & 11,683 & .01 & .01 \\
\hline November $\ldots$ & 475 & 210 & 310 & 18,446 & .01 & .01 \\
\hline December . ... & 645 & 325 & 403 & 24,780 & .02 & .02 \\
\hline The year & 7,175 & 69 & 759 & 547,022 & .03 & .39 \\
\hline $1899 . b$ & & & & & & \\
\hline January . . . . . & 870 & 500 & 702 & 43,165 & .027 & .031 \\
\hline February ..... & 1,020 & 555 & 768 & 42,653 & .030 & .031 \\
\hline March . . ... & 2,320 & 870 & 1,432 & 88,050 & .055 & .063 \\
\hline April & 1,020 & 615 & 870 & 51,769 & .034 & .038 \\
\hline May .. & 7,750 & 500 & 1,515 & 93,154 & .059 & .068 \\
\hline June . . & 12,000 & 475 & 1,959 & 116,569 & .076 & .085 \\
\hline July $\ldots \ldots \ldots$ & 3,570 & 395 & 1,415 & 87,005 & .055 & .063 \\
\hline August $=\ldots$ & 2,395 & 295 & 838 & 51,527 & .032 & .037 \\
\hline
\end{tabular}

a Twentieth Ann. Rept. U. S. Geol. Survey, pt. 4, 1900, p. 318.

$b$ Twenty-first Ann. Rept. U. S. Geol. Survey, pt. 4, 1901, p. 221.

IRR $96-04-4$ 
Estimated monthly discharge of Republican River at Junction, Kans._Continued.

\begin{tabular}{|c|c|c|c|c|c|c|}
\hline \multirow[b]{2}{*}{ Month. } & \multicolumn{3}{|c|}{ Discharge in second-feet. } & \multirow[b]{2}{*}{$\mid \begin{array}{c}\text { Total in acre- } \\
\text { feet. }\end{array}$} & \multicolumn{2}{|c|}{ Run-off. } \\
\hline & $\begin{array}{l}\text { Maxi- } \\
\text { mum. }\end{array}$ & $\begin{array}{l}\text { Mini- } \\
\text { mum. }\end{array}$ & Mean. & & $\begin{array}{l}\text { Second- } \\
\text { feet per } \\
\text { square } \\
\text { mile. }\end{array}$ & $\begin{array}{l}\text { Depth in } \\
\text { inches. }\end{array}$ \\
\hline 1899. & & & & & & \\
\hline September . . . & 345 & 100 & 187 & 11,127 & 0.007 & 0.008 \\
\hline October .... & 1,140 & 35 & 302 & 18,569 & .012 & .014 \\
\hline November & 395 & 63 & 175 & 10,413 & .007 & .008 \\
\hline December . - & 800 & 205 & 488 & 30,006 & .019 & .022 \\
\hline The year - & 12,000 & 35 & 888 & 644,007 & .034 & .468 \\
\hline $1900 . a$ & & & & & & \\
\hline January ..... & 670 & 400 & 559 & 34,372 & .02 & .02 \\
\hline February - - & 890 & 550 & 716 & 39,765 & .03 & .03 \\
\hline March . . . . & 4,875 & 610 & 1,327 & 81,594 & .05 & .06 \\
\hline April ..... & 3,450 & 500 & 1,465 & 87,173 & .06 & .07 \\
\hline May ....... & 3,260 & 735 & 1,362 & 83,746 & .05 & .06 \\
\hline June $\ldots . .$. & 975 & 450 & 554 & 32,965 & .02 & .02 \\
\hline July _ . . . - & 735 & 225 & 373 & 22,935 & .01 & .01 \\
\hline August .... & 450 & 150 & 275 & 16,909 & .01 & .01 \\
\hline September & 3,090 & 198 & $7 \% 1$ & 45,878 & .03 & .03 \\
\hline October ..... & 345 & 150 & 258 & 15,864 & .01 & .01 \\
\hline November. . . . & 225 & 130 & 162 & 9,640 & .01 & .01 \\
\hline December ... & 500 & 173 & 257 & 15,802 & .01 & .01 \\
\hline The year - & 4,875 & 130 & 673 & 486,643 & .03 & .34 \\
\hline $1901 . b$ & & & & & & \\
\hline January . . . - & 570 & 405 & 510 & 31,359 & .020 & .023 \\
\hline February _ . & 1,015 & 450 & 669 & 37,154 & .026 & .027 \\
\hline March $\ldots \ldots . .$. & 1,750 & 850 & 1,030 & 63,332 & .040 & .046 \\
\hline April & 5,010 & 930 & 1,530 & 91,041 & .059 & .066 \\
\hline May ..... & 1,015 & 405 & 747 & 45,931 & .029 & .033 \\
\hline June _.... & 510 & 315 & 406 & 24,159 & .016 & .018 \\
\hline July ...... & 450 & 75 & 177 & 10,883 & .007 & .008 \\
\hline August ... & 110 & 20 & 53 & 3,259 & .002 & .002 \\
\hline September & 3,160 & 20 & 906 & 53,911 & .036 & .040 \\
\hline October ...... & 770 & 405 & 564 & 34,679 & .022 & .025 \\
\hline November. . & 510 & 405 & 472 & 28,086 & .018 & .020 \\
\hline December .. & 660 & 450 & 594 & 36,524 & .023 & .027 \\
\hline The year - & 5,010 & 20 & 638 & 460,318 & .025 & .335 \\
\hline
\end{tabular}


Estimated monthly discharge of Republican River at Junction, Kans.-Continued.

\begin{tabular}{|c|c|c|c|c|c|c|}
\hline \multirow[b]{2}{*}{ Month. } & \multicolumn{3}{|c|}{ Discharge in second-feet. } & \multirow[b]{2}{*}{$\begin{array}{c}\text { Total in acre- } \\
\text { feet. }\end{array}$} & \multicolumn{2}{|c|}{ Run-off. } \\
\hline & $\begin{array}{l}\text { Maxi- } \\
\text { mum. }\end{array}$ & $\begin{array}{l}\text { Mini- } \\
\text { mum. }\end{array}$ & Mean. & & $\begin{array}{l}\text { Second- } \\
\text { feet per } \\
\text { square } \\
\text { mile. }\end{array}$ & $\begin{array}{l}\text { Depth in } \\
\text { inches. }\end{array}$ \\
\hline $1902 . a$ & & & & & & \\
\hline January .... & 945 & 600 & 710 & 43,656 & 0.03 & 0.03 \\
\hline February & 1,425 & 735 & 795 & 43,041 & .03 & .03 \\
\hline March .... & 1,480 & 570 & 887 & 54,539 & .03 & .03 \\
\hline April .. & 1,207 & 510 & 654 & 38,916 & .03 & .03 \\
\hline May ... & 7,800 & 482 & 2,128 & 130,846 & .08 & .09 \\
\hline June .... & 8,400 & 1,260 & 3,338 & 198,625 & .13 & .15 \\
\hline July ... & 23,100 & 840 & 7,887 & 484,953 & .30 & .35 \\
\hline August . . - & 11,700 & 260 & 2,046 & 125,804 & .08 & .09 \\
\hline September. & 10,500 & 88 & 1,646 & 97,944 & .06 & .07 \\
\hline October .... & 5.150 & 427 & 1,436 & 88,296 & .06 & .07 \\
\hline November.... & 787 & 400 & 471 & 28,026 & .02 & .02 \\
\hline December .... . & 2,443 & 220 & 422 & 25,944 & .02 & .02 \\
\hline The year & 23,100 & 88 & 1,867 & $1,360,590$ & .07 & .98 \\
\hline 1903. & & & & & & \\
\hline January ..... & 1,102 & 325 & 684 & 42,058 & .026 & .030 \\
\hline February - & 3,600 & 482 & 1,217 & 67,589 & .047 & .049 \\
\hline March ...... & 13,500 & 1,155 & 5,099 & 313,525 & .200 & .230 \\
\hline April .. & 1,102 & 375 & 624 & 37,130 & .024 & .027 \\
\hline May .... & 47,520 & 682 & 12,112 & 744,738 & .470 & .540 \\
\hline June .... & 44,280 & 1,370 & 8,162 & 485,673 & .310 & .340 \\
\hline July .... & 9,750 & 997 & 2,578 & 158,515 & .100 & .120 \\
\hline August ..... & 10,350 & 735 & 3,254 & 200,081 & .120 & .140 \\
\hline September & 3,020 & 400 & 859 & 51,114 & .033 & .037 \\
\hline October ...... & 1,315 & 240 & 466 & 28,653 & .018 & .021 \\
\hline November .. & 1,207 & 455 & 746 & 44,390 & .029 & .032 \\
\hline December. . . . & 1,102 & 570 & 757 & 46,546 & .029 & .033 \\
\hline The year & 47,520 & 240 & 3,046 & $2,220,012$ & .117 & 1.599 \\
\hline
\end{tabular}

$\alpha$ Water-Sup. and Irr. Paper No. 84, U. S. Geol. Survey, 1903, p. 102.

The hydrograph for this stream at this station is shown on Pl. XII, $C$. It is seen to resemble to some extent that for Kansas River at Lawrence, Kans. The minimum flow, however, occurs in the fall instead of in the winter. The maximum flow usually occurs some time between April 1 and July 31.

The monthly run-off per square mile prior to 1903 varied from 0.002 


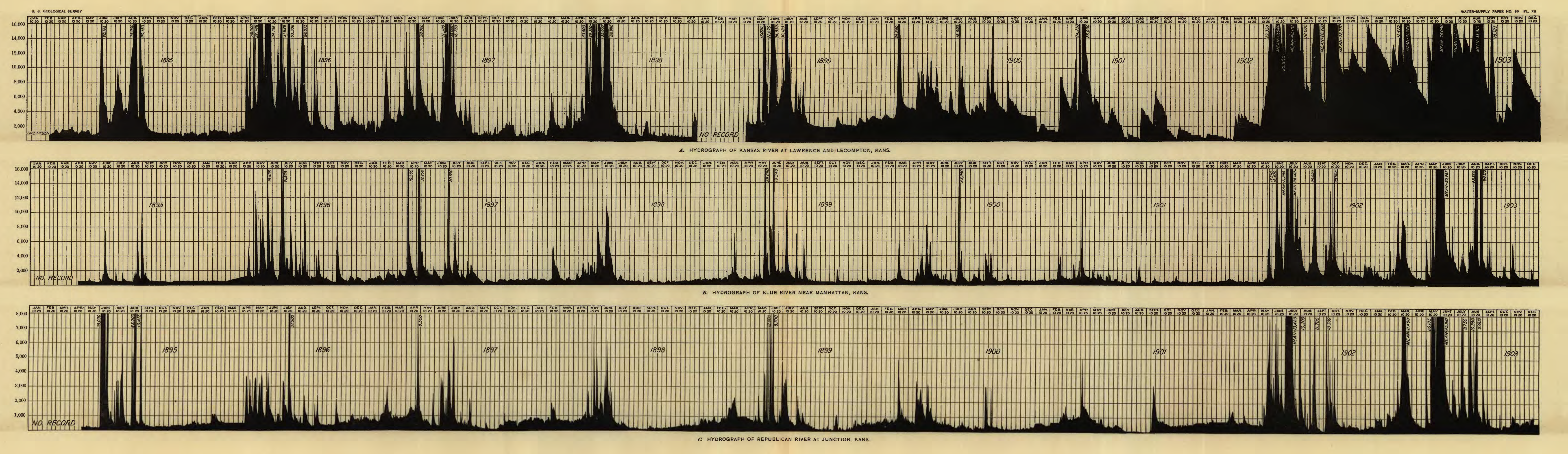


to 0.30 second-feet and the yearly run-off per square mile from 0.03 to 0.07 second-feet. The run-off for May, 1903 , was 0.47 second-feet and the yearly run-off for 1903 was 0.117 . The maximum monthly discharge is 230 times the minimum monthly discharge.

REPUBLICAN RIVER NEAR SUPERIOR, NEBR.

The station on Republican River near Superior, Nebr., is at a highway bridge, 150 feet upstream from a dam which diverts water into a mill race. The channel at this point is about 500 feet wide, broken by three piers. The bed is sand and silt and somewhat changeable. The velocity is sluggish at low stages. The first gage used at this place was an inclined timber fastened to the left bank just above the bridge. In the spring of 1898 two other gages were established here, one in the river a few feet upstream from the crest of the dam, the other in the mill race at a bridge about 150 feet below its head. The discharge of this mill race was measured at this bridge, and the difference between it and the river at the bridge gave the amount flowing over the dam. It was found, however, that the discharge of the mill race was regulated more or less by the mill below, so that there was no relation between the gage heights and the discharge. The method of remedying this defect is described on page 103 of WaterSupply and Irrigation Paper No. 84.

The run-off data obtained at this station are given in the following table:

Estimated monthly discharge of Republican River near Superior, Nebr.

[Drainage area, 22,347 square miles.]

\begin{tabular}{|c|c|c|c|c|c|c|}
\hline \multirow[b]{2}{*}{ Month. } & \multicolumn{3}{|c|}{ Discharge in second-feet. } & \multirow[b]{2}{*}{$\begin{array}{l}\text { Total in acre- } \\
\text { feet. }\end{array}$} & \multicolumn{2}{|c|}{ Run-off. } \\
\hline & $\begin{array}{l}\text { Maxi- } \\
\text { mum. }\end{array}$ & $\begin{array}{l}\text { Mini- } \\
\text { mum. }\end{array}$ & Mean. & & $\begin{array}{l}\text { Second- } \\
\text { feet per } \\
\text { square } \\
\text { mile. }\end{array}$ & $\begin{array}{l}\text { Depth in } \\
\text { inches. }\end{array}$ \\
\hline $1896 .^{a}$ & & & & & & \\
\hline June $^{b} \ldots \ldots$ & & & 627 & 13,244 & 0.028 & 0.011 \\
\hline July $e_{\ldots} \ldots$ & & & 1,179 & 70,155 & .093 & .059 \\
\hline August ..... & & . & 659 & 40,520 & .029 & .083 \\
\hline September $d$ & & & 279 & 16,048 & .012 & .013 \\
\hline October $\ldots=$ & & & 230 & 14,142 & .010 & .012 \\
\hline November $e_{-}$ & & $\ldots$. & 449 & 25,827 & .020 & .022 \\
\hline
\end{tabular}

$a$ Based on daily discharges published in Eighteenth Ann. Rept. U. S. Geol. Survey, pt. 4, 1897, p. 202. Discharge at both dam and mill race are included.

b For 11 days.

c For 30 days.

$d$ For 29 days.

$e$ For 29 days. 
Estimated monthly discharge of Republican River near Superior, Nebr.-Cont'd.

\begin{tabular}{|c|c|c|c|c|c|c|}
\hline \multirow[b]{2}{*}{ Month. } & \multicolumn{3}{|c|}{ Discharge in second-feet. } & \multirow[b]{2}{*}{$\begin{array}{c}\text { Total in acre- } \\
\text { feet. }\end{array}$} & \multicolumn{2}{|c|}{ Run-off. } \\
\hline & $\begin{array}{l}\text { Maxi- } \\
\text { mum. }\end{array}$ & $\begin{array}{l}\text { Mini- } \\
\text { mum. }\end{array}$ & Mean. & & $\begin{array}{l}\text { Second- } \\
\text { feet per } \\
\text { square } \\
\text { mile. }\end{array}$ & $\begin{array}{l}\text { Depth in } \\
\text { inches. }\end{array}$ \\
\hline $1897 . a^{\prime}$ & & & & & & \\
\hline January ${ }^{b} \ldots \ldots$ & 900 & 555 & 710 & 43,656 & 0.032 & 0.037 \\
\hline February $b$ & 1,520 & 420 & 906 & 50,316 & .041 & .043 \\
\hline $\operatorname{March}^{b} \ldots$ & 650 & 385 & 510 & 31,359 & .023 & .026 \\
\hline April ..... & 2,870 & 620 & 1,244 & 74,023 & .056 & .062 \\
\hline May ... - & 1,130 & 180 & 420 & 25,825 & .019 & .022 \\
\hline June ${ }^{b}$ & 750 & 180 & 359 & 21,362 & .016 & .018 \\
\hline July ....... & $4, \mathbf{3 1 0}$ & 119 & 922 & 56,690 & .041 & .047 \\
\hline August $\ldots \ldots \ldots$ & 1,460 & 94 & 259 & 15,924 & .012 & .014 \\
\hline September & 241 & 0 & 71 & 4,225 & .003 & .003 \\
\hline $1898 . c$ & & & & & & \\
\hline April $d \ldots$ & 2,130 & 490 & 755 & 44,926 & .03 & .03 \\
\hline May ... & 1,870 & 500 & 1,053 & 64,747 & .05 & .06 \\
\hline June ... & 2,300 & 560 & 1,235 & 73,487 & .06 & .07 \\
\hline July ....... & 1,345 & 220 & 479 & 29,453 & .02 & .02 \\
\hline August . . . . . & 380 & 100 & 195 & 11,990 & .01 & .01 \\
\hline September . ... & 470 & 185 & 289 & 17,197 & .01 & .01 \\
\hline October ...... & 365 & 145 & 264 & 16,233 & .01 & .01 \\
\hline November $e^{-.}$ & 470 & 320 & 382 & 22,731 & .02 & .02 \\
\hline - $\quad 1899 . f$ & & & & & & \\
\hline $\operatorname{March} g \ldots \ldots$ & 956 & 601 & 706 & 43,411 & .081 & .086 \\
\hline April ......... & 842 & 375 & 578 & 34,393 & .026 & .029 \\
\hline May - . . . & 1,800 & 292 & 511 & 31,420 & .023 & .026 \\
\hline June $\ldots \ldots$ & 4,036 & 141 & 531 & 31,597 & .021 & .023 \\
\hline July . . . . . . & 1,384 & 209 & 458 & 28,162 & .020 & .023 \\
\hline August $_{\text {... }}$ & 868 & 136 & 303 & 18,631 & .014 & .016 \\
\hline September.... & 102 & 6 & 50 & 2,975 & .002 & .002 \\
\hline October & 101 & 24 & 53 & 3,259 & .002 & .002 \\
\hline $1900 . h$ & ' & & & & & \\
\hline April $\ldots \ldots \ldots$ & 1,671 & 565 & 909 & 54,089 & .041 & .046 \\
\hline May - & 2,945 & 320 & 735 & 45,193 & .033 & .038 \\
\hline June................. & 674 & 250 & 392 & 23,326 & .018 & .020 \\
\hline
\end{tabular}

a Nineteenth Ann. Rept. U. S. Geol. Survey, pt. 4, 1899, p. 339. Discharges represent amount going over dam only; the mill race carries on an average, 85 second-feet.

bapproximate.

cTwentieth Ann. Rept. U. S. Geol. Survey, pt. 4, 1900, p. 317.

d For entire month; based on gage heights of April 20 to 30.

$e$ For entire month; based on gage heights of November 1 to 19

f'Twenty-first Ann. Rept. U. S. Geol. Survey, pt. 4, 1901, p. 220

$g$ For entire month, based on gage heights of March 19 to 31 .

hTwenty-second Ann. Rept. U. S. Geol. Survey, pt. 4, 190\%, p. 332. 
Estimated monthly discharge of Republican River near Superior, Nebr.-Cont'd.

\begin{tabular}{|c|c|c|c|c|c|c|}
\hline \multirow[b]{2}{*}{ Month. } & \multicolumn{3}{|c|}{ Discharge in second-feet. } & \multirow[b]{2}{*}{$\begin{array}{l}\text { Total in acre- } \\
\text { feet. }\end{array}$} & \multicolumn{2}{|c|}{ Run-off. } \\
\hline & $\begin{array}{l}\text { Maxi- } \\
\text { mum. }\end{array}$ & $\begin{array}{l}\text { Mini- } \\
\text { mum. }\end{array}$ & Mean. & & $\begin{array}{c}\text { Second- } \\
\text { feet per } \\
\text { square } \\
\text { mile. }\end{array}$ & $\begin{array}{l}\text { Depth in } \\
\text { inches. }\end{array}$ \\
\hline July 1900. & 349 & 67 & 159 & 9,7978 & 0.006 & 0.007 \\
\hline August ....... & 1,278 & 24 & 149 & 9,162 & .006 & .007 \\
\hline September - - & 2,010 & 8 & 156 & 9,283 & .006 & .007 \\
\hline October ..... & 148 & 26 & 69 & 4,243 & .003 & .003 \\
\hline November $a_{-}$ & 162 & 36 & 87 & 5,177 & .004 & .004 \\
\hline April 1901. & $1,50 \%$ & 637 & 961 & 57,183 & .043 & .048 \\
\hline May ........ & 622 & 146 & 364 & 22,381 & .016 & .018 \\
\hline June $\ldots . . . . .$. & 480 & 117 & 219 & 13,031 & .010 & .011 \\
\hline July ......... & 154 & 5 & 44 & 2,618 & .002 & .002 \\
\hline August & 856 & 5 & 70 & 4,304 & .003 & .003 \\
\hline September & 4,991 & 10 & 1,246 & 74,142 & .056 & .062 \\
\hline October & 1,490 & 285 & 443 & 27,239 & .020 & .020 \\
\hline November & 1,030 & 312 & 419 & 24,932 & .019 & .021 \\
\hline $1902 . c$ & & & & & & \\
\hline March 9 to 31 & -...- & & 675 & 29,453 & .03 & .02 \\
\hline April ....... & 740 & 390 & 555 & 33,020 & .02 & .02 \\
\hline May .... & 2,810 & 335 & 1,269 & 78,020 & .06 & .07 \\
\hline June ..... & 3,235 & 320 & 1,372 & 81,640 & .06 & .07 \\
\hline $\operatorname{July}^{d} \ldots$ & 12,490 & 970 & 3,080 & 189,360 & .14 & .16 \\
\hline August & 1,920 & 330 & 674 & 41,440 & .03 & .03 \\
\hline September & 10,875 & 155 & 1,175 & 69,910 & .05 & .06 \\
\hline October $\ldots$ & 1,995 & 520 & 937 & 57,610 & .04 & .05 \\
\hline November - & 970 & 460 & 622 & 37,010 & .03 & .03 \\
\hline 1903. & & & & & & \\
\hline March 14-31 . . & 7,750 & 1,260 & 2,692 & 96,120 & .120 & .080 \\
\hline April ........ & 1,260 & 705 & 918 & 54,625 & .041 & .046 \\
\hline May .... & 14,100 & 845 & 4,491 & 276,141 & .201 & .232 \\
\hline June . ... & 6,455 & 835 & 1,921 & 114,307 & .086 & .096 \\
\hline July .... & 7,825 & 465 & 1,948 & 119,7778 & .087 & .100 \\
\hline August & 3,285 & 520 & 1,230 & 75,630 & .055 & .063 \\
\hline September & 700 & 270 & 389 & 23,147 & .017 & .019 \\
\hline October & 390 & 245 & 326 & 20,045 & .015 & .017 \\
\hline November ... & 690 & 130 & 417 & 24,813 & .019 & .021 \\
\hline
\end{tabular}

a For entire month, based on gage heights of November 1 to 24 .

$b$ Water-Sup. and Irr. Paper No. 75, U. S. Geol. Survey, 1903, p. 140.

$c$ Water-Sup. and Irr. Paper No. 84, U. S. Geol. Survey, 1903, p. 105.

d Exclusive of four days flood discharge. 
It is seen that the minimum monthly discharge occurs in September and is less than 50 second-feet. The smallest daily discharge is 0 . The maximum monthly discharge is 4,491 second-feet, which is 102 times the minimum monthly discharge. The monthly run-off per square mile varies from 0.002 to 0.20 second-feet.

\section{REPUBLICAN RIVER NEAR BENKELMAN, NEBR.}

A station was established on North Fork of Republican River about 2 miles west of Benkelman, Nebr., November 4, 1894. A station was also established on South Fork near Benkelman, at about the same time. The former station was maintained continuously until September 1, 1895. The other was maintained, with short breaks, to September 31, 1895. The stream bed at these stations is sandy and shifting, and each flood changes the channel by a considerable amount, so that a rating curve at either station was applicable for only a few months. Stations were again established at these places in May, 1903.

The monthly discharge was as follows:

Estimated monthly discharge of Republican River at Benkelman, Nebr.

\begin{tabular}{|c|c|c|c|c|}
\hline \multirow{2}{*}{ Month. } & \multicolumn{3}{|c|}{ Discharge in second-feet. } & \multirow{2}{*}{$\begin{array}{l}\text { Total in } \\
\text { aere-feet. }\end{array}$} \\
\hline & $\begin{array}{l}\text { Maxi- } \\
\text { mum. }\end{array}$ & $\begin{array}{l}\text { Mini- } \\
\text { mum. }\end{array}$ & Mean. & \\
\hline $\begin{array}{c}\text { NORTH FORK. } \\
1903 .\end{array}$ & & & & \\
\hline May $20-31 \ldots$ & 71 & 47 & 58 & 1,382 \\
\hline June $\ldots \ldots \ldots$ & 81 & 43 & 59 & 5,511 \\
\hline July .......... & 112 & 19 & 39 & 2,398 \\
\hline August ...... & 61 & 26 & 32 & 1,968 \\
\hline September . . - & $4 \%$ & 19 & 39 & 2,321 \\
\hline October & 54 & 43 & 49 & 3,013 \\
\hline November 1-20a $a_{\ldots} \ldots \ldots \ldots$ & 64 & 50 & 56 & 2,204 \\
\hline $\begin{array}{c}\text { SOUTH FORK. } \\
1903 .\end{array}$ & & & & \\
\hline May $20-31 \ldots \ldots$ & 57 & 36 & 48 & 1,148 \\
\hline June .......... & 65 & 7 & 37 & 2,202 \\
\hline July .......... & 36 & 7 & 15 & 922 \\
\hline August $\ldots . . . . . .$. & 79 & 7 & 25 & 1,537 \\
\hline September $b$ & 22 & 7 & 11 & 655 \\
\hline October & 50 & 22 & 39 & 2,398 \\
\hline November 1-20 $a$ & $65-$ & 50 & 57 & 2,269 \\
\hline
\end{tabular}

a Frozen November 21 to December 31

$b$ Records from 6 to 13 , inclusive, are missing. 
SOLOMON RIVER AT BELOIT AND NEAR NILES, KANS.

A station was established on Solomon River at a highway bridge in Beloit, April 22, 1895, and was maintained continuously until June 30, 1897, when it was discontinued on account of poor section. The present gaging station on Solomon River is located 56 miles down the river from Beloit, at an iron bridge abont $1 \frac{1}{2}$ miles from Niles. It was established May 5, 1897, and has been maintained continuously since that date. The channel at the present station is about 150 feet wide, nearly straight for 100 feet above and below, and broken by two piers. The bed is clay and silt. The velocity is sluggish at low stages. Surface fluctuations are measured with a wire gage.

The run-off data obtained at these two stations on Solomon River are given in the following table:

Estimated monthly discharge of Solomon River at Beloit, Kans.

[Drainage area, 5,539 square miles.]

\begin{tabular}{|c|c|c|c|c|c|c|}
\hline \multirow[b]{2}{*}{ Month. } & \multicolumn{3}{|c|}{ Discharge in second-feet. } & \multirow[b]{2}{*}{$\begin{array}{c}\text { Total in acre- } \\
\text { feet. }\end{array}$} & \multicolumn{2}{|c|}{ Run-off. } \\
\hline & $\begin{array}{l}\text { Maxi- } \\
\text { mum. }\end{array}$ & $\begin{array}{l}\text { Mini- } \\
\text { mum. }\end{array}$ & Mean. & & $\begin{array}{c}\text { Second- } \\
\text { feet per } \\
\text { square } \\
\text { mile. }\end{array}$ & $\begin{array}{l}\text { Depth in } \\
\text { inches. }\end{array}$ \\
\hline $1895 . a$ & & & & & & \\
\hline July ........... & $b 21,000$ & 159 & 2,202 & 135,396 & 0.399 & 0.460 \\
\hline August ......... & $b 24,000$ & 172 & 1,699 & 100,164 & .294 & .339 \\
\hline September . . . . . . . & 615 & 14 & 156 & 9,283 & .028 & .032 \\
\hline October ................ & 62 & $\gamma$ & 28 & 1,722 & .005 & .006 \\
\hline November . . . . . . . . & 26 & 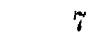 & 23 & 1,369 & .004 & .005 \\
\hline December . . . . . . . . & 250 & 7 & 114 & $\%, 010$ & .021 & .024 \\
\hline $1896 . a$ & & & & & & \\
\hline January _... $\ldots \ldots$ & 121 & 5 & 88 & 5,411 & .016 & .018 \\
\hline February .................. & 121 & 19 & 103 & 5,925 & .018 & .020 \\
\hline 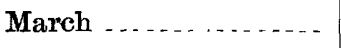 & 123 & 8 & 94 & 5,780 & .017 & .019 \\
\hline April .............. & $b 18,500$ & 8 & 1,658 & 98,658 & .300 & .334 \\
\hline May ................... & 4,700 & 72 & 429 & 26,378 & $.07 \%$ & .089 \\
\hline June ....................... & 8,740 & 104 & 852 & 50,698 & .154 & .172 \\
\hline July .......... & $b 21,800$ & 108 & 1, 238 & 76,122 & .226 & .255 \\
\hline August _. . . & 803 & 92 & 354 & 21,767 & .065 & .073 \\
\hline September .............. & 960 & 28 & 130 & 7,735 & .023 & .026 \\
\hline October .................... & 6,760 & 10 & 302 & 18,569 & .055 & .062 \\
\hline 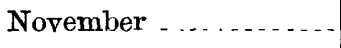 & 117 & 34 & 76 & $\dot{4}, 522$ & .013 & .015 \\
\hline December ............. & 124 & 38 & 92 & 5,657 & .017 & .019 \\
\hline The year ......... & $b 21.800$ & 5 & 451 & 327,222 & .083 & 11.02 \\
\hline
\end{tabular}

a Eighteenth Ann. Rept. U. S. Geol. Survey, pt. 4, 1897, pp. 209-210.

$b$ Estimated. NoTE.-Recent measurements show that these estimates are too large. 
Estimated monthly discharge of Solomon River at Beloit, Kans.-Continued.

\begin{tabular}{|c|c|c|c|c|c|c|}
\hline \multirow[b]{2}{*}{ Month. } & \multicolumn{3}{|c|}{ Discharge in second-feet. } & \multirow[b]{2}{*}{$\begin{array}{l}\text { Total in acre. } \\
\text { feet. }\end{array}$} & \multicolumn{2}{|c|}{ Run-off. } \\
\hline & $\begin{array}{l}\text { Maxi- } \\
\text { mum. }\end{array}$ & $\begin{array}{l}\text { Mini- } \\
\text { mum. }\end{array}$ & Mean. & & $\begin{array}{c}\text { Second- } \\
\text { feet per } \\
\text { square } \\
\text { mile. }\end{array}$ & $\begin{array}{l}\text { Depth in } \\
\text { inches. }\end{array}$ \\
\hline $1897 . a$ & & & & & & \\
\hline January & 225 & 16 & 130 & 8,024 & 0.023 & 0.027 \\
\hline February & $38 \%$ & 20 & 193 & 10,724 & .035 & .036 \\
\hline March - & 312 & 92 & 227 & 13,933 & .041 & .047 \\
\hline April & 7,470 & 180 & 663 & 39,463 & .120 & .133 \\
\hline May . & 368 & 18 & 150 & 9,254 & .027 & .031 \\
\hline June . . . . . . . . & 6,400 & 19 & 1,377 & 81,913 & .249 & .278 \\
\hline
\end{tabular}

a Nineteenth Ann. Rept. U. S. Geol. Survey, pt. 4, 1899, p. 341.

Estimated monthly discharge of Solomon River near Niles, Kans.

[Drainage area, 6,815 square miles.]

\begin{tabular}{|c|c|c|c|c|c|c|}
\hline \multirow[b]{2}{*}{ Month. } & \multicolumn{3}{|c|}{ Discharge in second-feet. } & \multirow[b]{2}{*}{$\begin{array}{l}\text { Total in acre- } \\
\text { feet. }\end{array}$} & \multicolumn{2}{|c|}{ Run-off. } \\
\hline & $\begin{array}{l}\text { Maxi- } \\
\text { mum. }\end{array}$ & $\begin{array}{l}\text { Mini- } \\
\text { mum. }\end{array}$ & Mean. & & $\begin{array}{l}\text { Second- } \\
\text { feet per } \\
\text { square } \\
\text { mile. }\end{array}$ & $\begin{array}{l}\text { Depth in } \\
\text { inches. }\end{array}$ \\
\hline $1897 . a$ & & & & & & \\
\hline May ${ }^{b} \ldots$ & 669 & 161 & 267 & 16,411 & 0.039 & 0.045 \\
\hline June _ . & 4,500 & 103 & 1,083 & 64,433 & .159 & .177 \\
\hline July & 5,380 & 215 & 838 & 51,551 & .123 & .142 \\
\hline August & 320 & 108 & 193 & 11,892 & .028 & .033 \\
\hline September & 200 & 65 & 106 & 6,319 & .016 & .017 \\
\hline October & 142 & 62 & 97 & 5,976 & .014 & .016 \\
\hline November - - & 154 & 86 & 114 & 6,784 & .017 & .019 \\
\hline December . . . . . . . . & 161 & 60 & 100 & 6,124 & .015 & .017 \\
\hline $1898 . c$ & & & & & & \\
\hline January ..... & 172 & 126 & 155 & 9,531 & .02 & .02 \\
\hline February .... & 260 & 109 & 164 & 9,108 & .02 & .02 \\
\hline March ..... & 190 & 98 & 131 & 8,055 & .02 & .02 \\
\hline April . & 353 & 109 & 146 & 8,688 & .02 & .02 \\
\hline May ..... & 677 & 160 & 243 & 14,942 & .04 & .04 \\
\hline June .... & 1,175 & 196 & 534 & 31,775 & .08 & .09 \\
\hline July ..... & 335 & 79 & 156 & 9,592 & .02 & .02 \\
\hline August - & 103 & 35 & 56 & 3,443 & .01 & .01 \\
\hline September & 190 & 42 & 79 & 4,701 & .01 & .01 \\
\hline
\end{tabular}

a Nineteenth Ann. Rept. U. S. Geol. Survey, pt. 4, 1899, p. 343.

$b$ Estimated from gage heights of May 6 to 31 .

cTwentieth Ann. Rept. U. S. Geol. Survey, pt. 4, 1900, p. 314. 
Estimated monthly discharge of Solomon River near Niles, Kans.-Continued.

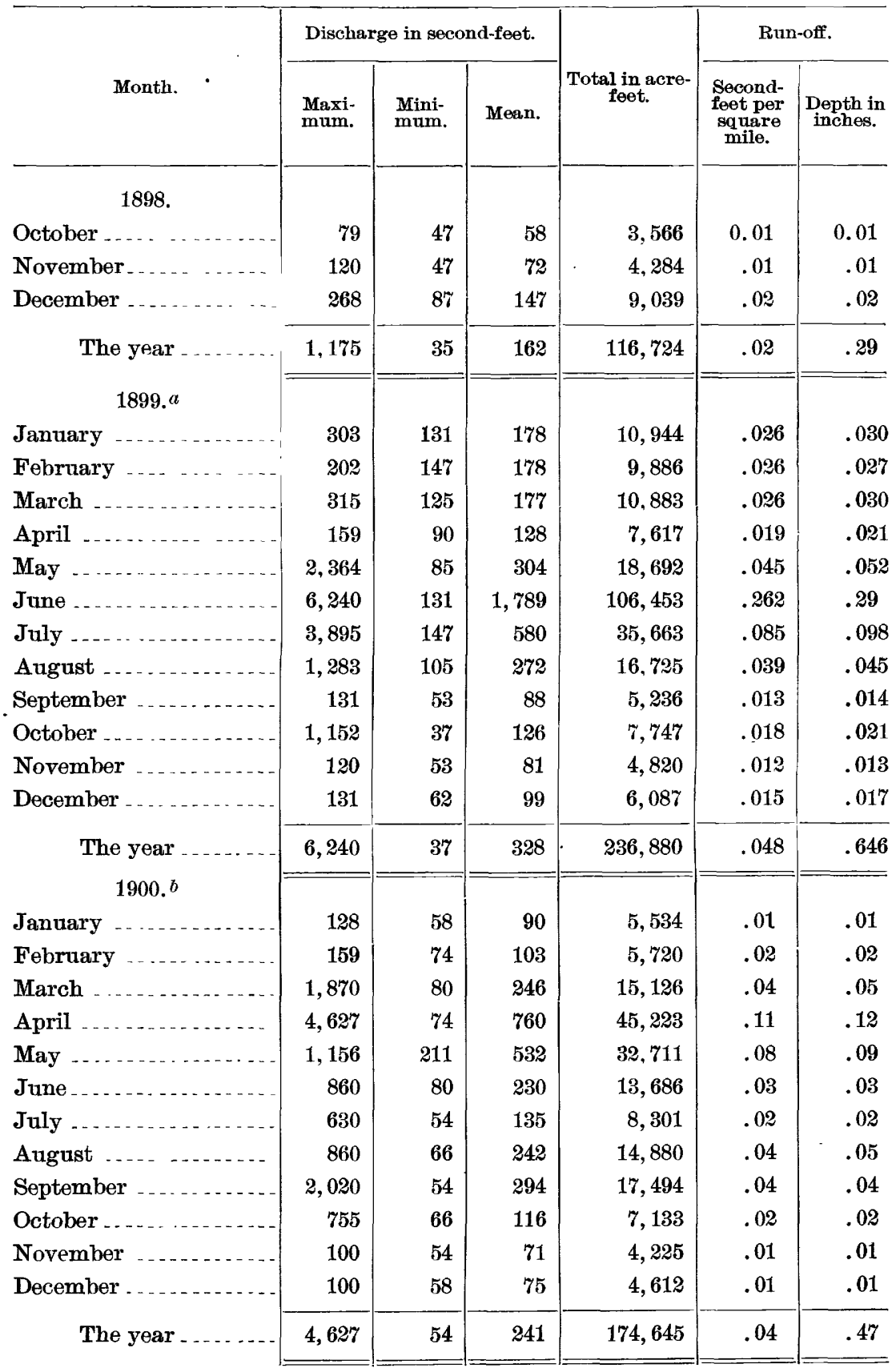


Estimated monthly discharge of Solomon River near Niles, Kans,-Continued.

\begin{tabular}{|c|c|c|c|c|c|c|}
\hline \multirow[b]{2}{*}{ Month. } & \multicolumn{3}{|c|}{ Discharge in second-feet. } & \multirow[b]{2}{*}{$\begin{array}{c}\text { Total in acre- } \\
\text { feet. }\end{array}$} & \multicolumn{2}{|c|}{ Run-off. } \\
\hline & $\begin{array}{l}\text { Maxi- } \\
\text { mum. }\end{array}$ & $\begin{array}{l}\text { Mini- } \\
\text { mum. }\end{array}$ & Mean. & & $\begin{array}{l}\text { Second- } \\
\text { feet per } \\
\text { square } \\
\text { mile. }\end{array}$ & $\begin{array}{l}\text { Depth in } \\
\text { inches. }\end{array}$ \\
\hline $1901 . a$ & & & & & & \\
\hline January -. & 114 & 46 & 91 & 5,595 & 0.013 & 0.015 \\
\hline February ... & 193 & 54 & 90 & 4,998 & .013 & .014 \\
\hline March .... & 341 & 100 & 152 & 9,346 & .022 & .025 \\
\hline April ..... & 2,020 & 114 & 452 & 26,896 & .066 & .074 \\
\hline May ...... & 303 & 89 & 142 & 8,731 & .021 & .024 \\
\hline June . . . . . . & 989 & 46 & 157 & 9,342 & .023 & .026 \\
\hline July ....... & 54 & 7 & 27 & 1,660 & .004 & .005 \\
\hline August ...... & 62 & 7 & 18 & 1,107 & .003 & .003 \\
\hline September - - & 1,604 & 70 & 243 & 14,460 & .036 & .040 \\
\hline October $\ldots . . . .$. & 89 & 38 & 67 & 4,120 & .010 & .012 \\
\hline November .... & 176 & 38 & 99 & 5,891 & .015 & .017 \\
\hline December .... . & 100 & 54 & 79 & 4,858 & .012 & .014 \\
\hline The year & 2,020 & 7 & 135 & 97,004 & .020 & .269 \\
\hline $1902 . b$ & & & & & & \\
\hline January - . . . & 152 & 94 & 106 & 6,517 & .02 & .02 \\
\hline February . . . . . & 142 & 102 & 119 & 6,608 & .02 & .02 \\
\hline March $\ldots \ldots$ & 207 & 38 & 101 & 6,210 & .02 & .02 \\
\hline April ...... & 152 & 54 & 89 & 5,296 & .01 & .01 \\
\hline May . . . . . & 1,415 & 38 & 285 & 17,524 & .04 & .05 \\
\hline June . . . . & 6,155 & 316 & 1,392 & 82,830 & .20 & .22 \\
\hline July ... & 7,040 & 252 & 2,492 & 153,227 & .37 & .43 \\
\hline August ...... & 2,375 & 299 & 847 & 52,080 & .12 & .14 \\
\hline September & 7,040 & 132 & 1,392 & 82,830 & .20 & .22 \\
\hline October ....... & 7,780 & 761 & 2,263 & 139,145 & .33 & .38 \\
\hline November .... & 855 & 470 & 601 & 35,764 & .09 & .10 \\
\hline December .... & 490 & 316 & 402 & 24,718 & .06 & .07 \\
\hline The year & 7,780 & 38 & 841 & 612,749 & .12 & 1.68 \\
\hline 1903. & & & & & & \\
\hline January - ... & 410 & 282 & 341 & 20,967 & .050 & .058 \\
\hline February ..... & 830 & 237 & 356 & 19,882 & .052 & .054 \\
\hline March & 5,002 & 587 & 1,866 & 114,736 & .270 & .310 \\
\hline April $\ldots . .$. & 564 & 120 & 345 & 20,529 & .051 & .057 \\
\hline May ... & 9,946 & 635 & 4,835 & 297,292 & .710 & .820 \\
\hline June..... & 10,602 & 1,765 & 4,447 & 264,615 & .650 & .720 \\
\hline
\end{tabular}

a Water-Sup. and Irr. Paper No. 75, U. S. Geol. Survey, 1903, p. 142. $b$ Water-Sup. and Irr. Paper No. 84, U. S. Geol. Survey, 1908, p. 107. 
Estimated monthly discharge of Solomon River near Niles, Kans.-Continued.

\begin{tabular}{|c|c|c|c|c|c|c|}
\hline \multirow[b]{2}{*}{ Month. } & \multicolumn{3}{|c|}{ Discharge in second-feet. } & \multirow[b]{2}{*}{$\begin{array}{c}\text { Total in acre- } \\
\text { feet. }\end{array}$} & \multicolumn{2}{|c|}{ Run-off. } \\
\hline & $\begin{array}{l}\text { Maxi- } \\
\text { mum. }\end{array}$ & $\begin{array}{l}\text { Mini- } \\
\text { mum. }\end{array}$ & Mean. & & $\begin{array}{l}\text { Second- } \\
\text { feet per } \\
\text { square } \\
\text { mile. }\end{array}$ & $\begin{array}{l}\text { Depth in } \\
\text { inches. }\end{array}$ \\
\hline 1908. & - & & & & & \\
\hline July ... . . . . & 4,074 & 835 & 1,658 & 101,946 & 0.240 & 0.280 \\
\hline August ....... & 7,091 & 1,190 & 3,625 & 222,893 & .530 & .610 \\
\hline September .... . & 2,460 & 472 & 970 & 57,719 & .140 & .160 \\
\hline October $\ldots \ldots$ & 495 & 363 & 427 & 26,255 & .063 & .073 \\
\hline November.... ..... & 760 & 343 & 456 & 27,134 & .067 & .075 \\
\hline The period & 10,602 & 120 & 1,611 & $1,173,958$ & .235 & 3.217 \\
\hline
\end{tabular}

The hydrographs for this stream at these stations are shown in Pl. XIII, $B$, p. 64 . The minimum monthly flow was very small, and less than 20 second-feet in August, 1901. The flood flow is occasionally very large, and was 4,835 second-feet in May, 1903 . The maximum monthly discharge is 269 times the minimum monthly discharge. The monthly run-off per square mile varies from 0.003 to 0.710 .

SALINE RIVER AT BEVERLY AND NEAR SALINA, KANS.

A station was established on Saline River at Beverly, April 18, 1895, and was maintained continuously from that date to June 30,1897 , when it was discontinued on account of poor section. The present station on Saline River is located at a highway bridge, about $4 \frac{1}{2}$ miles north of Salina and 24 miles down the river from Beverly. It was established May 4, 1897, to take the place of the station at Beverly, and has been maintained continuously from that time to the present. The channel is about 170 feet wide, nearly straight for a short distance above and below the bridge, and without piers. The bed is soft material; the velocity sluggish. Surface fluctuations are measured with a wire gage. Both banks are subject to overflow during floods. 
The run-off results obtained at this station are given in the following tables:

Estimated monthly discharge of Saline River at Beverly, Kans.

[Drainage area, 2,730 square miles.]

\begin{tabular}{|c|c|c|c|c|c|c|}
\hline \multirow{2}{*}{ Month. } & \multicolumn{3}{|c|}{ Discharge in second-feet. } & \multirow[b]{2}{*}{$\begin{array}{c}\text { Total in acre- } \\
\text { feet. }\end{array}$} & \multicolumn{2}{|c|}{ Run-off. } \\
\hline & $\begin{array}{l}\text { Maxi- } \\
\text { mum. }\end{array}$ & $\begin{array}{l}\text { Mini- } \\
\text { mum. }\end{array}$ & Mean:- & & $\begin{array}{l}\text { Second- } \\
\text { feet per } \\
\text { square } \\
\text { mile. }\end{array}$ & $\begin{array}{l}\text { Depth in } \\
\text { inches. }\end{array}$ \\
\hline 1895. $a$ & & & & & & \\
\hline July _...... & $b 10,000$ & 73 & 574 & 35,294 & 0.201 & 0.232 \\
\hline August & 339 & 58 & 101 & 6,210 & .037 & .043 \\
\hline September & 92 & 9 & 38 & 2,261 & .014 & .016 \\
\hline October ..... & 58 & 6 & 27 & 1,660 & .010 & .012 \\
\hline November - :- & 62 & 9 & 33 & 1,964 & .012 & .013 \\
\hline December .. . . & 57 & 13 & 33 & 2,029 & .012 & .014 \\
\hline $1896 . a$ & & & & & & \\
\hline January & 76 & 26 & 52 & 3,197 & .019 & .022 \\
\hline February & 96 & 33 & 51 & 2,934 & .018 & .020 \\
\hline March & 65 & 33 & 49 & 3,013 & .018 & .020 \\
\hline April - & 693 & 37 & 151 & 8,986 & .055 & .062 \\
\hline May ..... & 3,000 & 45 & 313 & 19,245 & .114 & .132 \\
\hline June...... & $b 16,000$ & 167 & 2,291 & 136,324 & .839 & .936 \\
\hline July _. & 679 & 103 & 286 & 17,586 & .104 & .120 \\
\hline August ....... & 493 & 41 & 107 & 6,579 & .037 & .045 \\
\hline September & 90 & 33 & 58 & 3,451 & .021 & .024 \\
\hline October & $b 6,130$ & 31 & 260 & 15,987 & .095 & .109 \\
\hline November . ... & 188 & 41 & 75 & 4,463 & .027 & .031 \\
\hline December & 98 & 31 & 62 & 3,505 & .023 & .027 \\
\hline The year & $b 16,000$ & 26 & 313 & 225,270 & .114 & 1.548 \\
\hline $1897 . c$ & & & & & & \\
\hline January .... & 108 & 17 & 48 & 2,927 & .017 & .020 \\
\hline February & 243 & 27 & 73 & 4,054 & .026 & .027 \\
\hline March $\ldots \ldots$ & 67 & .32 & 46 & 2,835 & .017 & .019 \\
\hline April & 626 & 49 & 192 & 11,424 & .070 & .078 \\
\hline May .......... & 357 & 53 & 146 & 8,953 & .053 & .061 \\
\hline June . . . . . . . & $b_{11}, 000$ & 38 & 452 & 26,920 & .166 & .185 \\
\hline
\end{tabular}

a Eighteenth Ann. Rept. U. S. Geol. Survey, pt. 4, 1897, p. 212.

$b$ Approximate.

cNineteenth Ann. Rept. U. S. Geol. Survey, pt. 4, 1899, p. 344. 
Estimated monthly discharge of Saline River near Salina, Kans.

[Drainage area, 3,311 square miles.]

\begin{tabular}{|c|c|c|c|c|c|c|}
\hline \multirow[b]{2}{*}{ Month. } & \multicolumn{3}{|c|}{ Discharge in second-feet. } & \multirow{2}{*}{$\begin{array}{l}\text { Total in acre- } \\
\text { feet. }\end{array}$} & \multicolumn{2}{|c|}{ Run-oft. } \\
\hline & $\begin{array}{l}\text { Maxi- } \\
\text { mum. }\end{array}$ & $\begin{array}{l}\text { Mini- } \\
\text { mum. }\end{array}$ & Mean. & & $\begin{array}{c}\text { Second } \\
\text { feet per } \\
\text { square } \\
\text { mile. }\end{array}$ & $\begin{array}{l}\text { Depth in } \\
\text { inches. }\end{array}$ \\
\hline $189 \% . a$ & & & & & & \\
\hline May . . . . . . . & 335 & 79 & 147 & 9,039 & 0.044 & 0.051 \\
\hline June ... . . . . & $b 4,400$ & 51 & 256 & 15,203 & .077 & .085 \\
\hline July _...... & ${ }^{a} 685$ & 36 & 83 & 5,104 & .025 & .028 \\
\hline August ........ & 381 & 28 & 74 & 4,532 & .022 & .025 \\
\hline September - & 57 & 20 & 30 & 1,803 & .009 & .010 \\
\hline October .... & 70 & 16 & 32 & 1,955 & .010 & .011 \\
\hline November - & 48 & 26 & 38 & 2,279 & .012 & .013 \\
\hline December .. . & 46 & 28 & 41 & 2,521 & .012 & .014 \\
\hline $1898 . c$ & & & & & & \\
\hline January ... & 82 & 40 & 57 & 3,505 & .02 & .02 \\
\hline February -- & 94 & 34 & 50 & 2,777 & .02 & .02 \\
\hline March ..... & 46 & 24 & 37 & 2,275 & .01 & .01 \\
\hline April ... & 60 & 24 & 35 & 2,083 & .01 & .01 \\
\hline May .... & 1,095 & 34 & 109 & 6,702 & .03 & .04 \\
\hline June . . . . . . & 1,100 & 72 & 271 & 16,126 & .08 & .09 \\
\hline July . . . . & 421 & 22 & 86 & 5,288 & .03 & .03 \\
\hline August ... & 32 & 7 & 20 & 1,230 & .01 & .01 \\
\hline September _. . _ _. . . & 970 & 6 & 121 & 7,440 & .04 & .04 \\
\hline October & 52 & 22 & 35 & 2,152 & .01 & .01 \\
\hline November . & 40 & 15 & 25 & 1,488 & .01 & .01 \\
\hline Decernber ... & 690 & 29 & 144 & 8,854 & .04 & .04 \\
\hline The year . . . ..... & 1,100 & 6 & 83 & 59,920 & .03 & .33 \\
\hline $1899 . d$ & & & & & & \\
\hline January & 110 & 60 & 67 & 4,120 & .020 & .023 \\
\hline February . . . . . . & 102 & 50 & 63 & 3,499 & .019 & .020 \\
\hline March . . . . . . . & 117 & 50 & 80 & 4,919 & .024 & .028 \\
\hline April _............ & 72 & 30 & 53 & 3,154 & .016 & .018 \\
\hline May & 1,010 & 18 & 155 & 9,531 & .047 & .054 \\
\hline June _ - & 5,000 & 110 & 1,334 & 79,378 & .403 & .45 \\
\hline July _..... & 684 & 132 & 279 & 17,155 & .084 & .097 \\
\hline August ... . . & 152 & 62 & 100 & 6,149 & .030 & .035 \\
\hline September . . . . . & 102 & 55 & 68 & 4,046 & .021 & .023 \\
\hline
\end{tabular}

a Nineteenth Ann. Rept. U. S. Geol. Survey, pt. 4, 1899, p. 346 b Approximate.

c Twentieth Ann. Rept. U. S. Geol. Survey, pt. 4, 1900, p. 316.

$d$ Twenty-first Ann. Rept. U. S. Geol. Survey, pt. 4, 1901, p. 224. 
Estimated monthly discharge of Saline River near Salina, Kans, -Continued.

\begin{tabular}{|c|c|c|c|c|c|c|}
\hline \multirow[b]{2}{*}{ Month. } & \multicolumn{3}{|c|}{ Discharge in second-feet. } & \multirow[b]{2}{*}{$\begin{array}{l}\text { Total in acre- } \\
\text { feet. }\end{array}$} & \multicolumn{2}{|c|}{ Run-off. } \\
\hline & $\begin{array}{l}\text { Maxi- } \\
\text { mum. }\end{array}$ & $\begin{array}{l}\text { Mini- } \\
\text { mum- }\end{array}$ & Mean. & & $\begin{array}{c}\text { Second- } \\
\text { feet per } \\
\text { square } \\
\text { mile. }\end{array}$ & $\begin{array}{l}\text { Depth in } \\
\text { inches. }\end{array}$ \\
\hline 1899. & & & & & & \\
\hline October ....... & 386 & 40 & 79 & 4,858 & 0.024 & 0.028 \\
\hline November & 181 & 70 & 88 & 5,236 & .027 & .030 \\
\hline December . . & 102 & 70 & 84 & 5,165 & .025 & .029 \\
\hline The year - & 5,000 & 18 & 204 & 147,210 & .062 & .835 \\
\hline $1900 . a$ & & & & & & \\
\hline January & 55 & 42 & 49 & 3,013 & .01 & .01 \\
\hline February - & 55 & 42 & 47 & 2,610 & .01 & .01 \\
\hline March .......... & 700 & 44 & 114 & 7,010 & .03 & .03 \\
\hline April . . . . . . . & 2,930 & 50 & 471 & 28,026 & .04 & .06 \\
\hline May ....... & 1,100 & 166 & 347 & 21,336 & .10 & .12 \\
\hline June....... & $1,42^{r}$ & 70 & 245 & 14,578 & .07 & .08 \\
\hline July . . . . . & 3,370 & 46 & 382 & 23,488 & .12 & .14 \\
\hline August ... & 370 & 36 & 76 & 4,673 & .02 & .02 \\
\hline September - & 1,160 & 40 & 120 & 7,141 & .04 & .04 \\
\hline October & 133 & 40 & 56 & 3,443 & .02 & .02 \\
\hline November ... & 76 & 46 & 51 & 3,035 & .02 & .02 \\
\hline December . . . . . . & 60 & 46 & 53 & 3,259 & .02 & .02 \\
\hline The year. & 3,370 & 36 & 168 & 121,612 & .05 & $.6 \%$ \\
\hline $1901 . b$ & & & & & & \\
\hline January ...... & 71 & 47 & 56 & 3,443 & .017 & .020 \\
\hline February ..... & 115 & 55 & 74 & 4,110 & .022 & .023 \\
\hline March ..... & 122 & 51 & 76 & 4,673 & .023 & .027 \\
\hline April ...... & 3,580 & 85 & 470 & 27,967 & .142 & .158 \\
\hline May ......... & 315 & 60 & 112 & 6,887 & .034 & .039 \\
\hline June $\ldots . . . . .$. & 2,680 & 37 & 376 & 22,374 & .114 & .127 \\
\hline July . . . . . & 51 & 22 & 31 & 1,906 & .009 & .010 \\
\hline August ..... & 153 & 25 & 47 & 2,890 & .014 & .016 \\
\hline September .... & 85 & 40 & 53 & 3,154 & .016 & .018 \\
\hline October ........ & 60 & 37 & 47 & 2,890 & .014 & .016 \\
\hline November ........... & 65 & 40 & 53 & 3,154 & .016 & .018 \\
\hline December $\ldots . . . . . .$. & 65 & 47 & 57 & 3,505 & .017 & .020 \\
\hline The year - & 3,580 & 22 & 121 & 86,953 & .036 & .492 \\
\hline
\end{tabular}


Estimated monthly discharge of Saline River near Salina, Kans.-Continued.

\begin{tabular}{|c|c|c|c|c|c|c|}
\hline \multirow[b]{2}{*}{ Month. } & \multicolumn{3}{|c|}{ Discharge in second-feet. } & \multirow[b]{2}{*}{$\begin{array}{c}\text { Total in acre- } \\
\text { feet. }\end{array}$} & \multicolumn{2}{|c|}{ Run-off. } \\
\hline & $\begin{array}{l}\text { Maxi- } \\
\text { mum. }\end{array}$ & $\begin{array}{l}\text { Mini- } \\
\text { mum. }\end{array}$ & Mean. & & $\begin{array}{c}\text { Second- } \\
\text { feet per } \\
\text { square } \\
\text { mile. }\end{array}$ & $\begin{array}{l}\text { Depth in } \\
\text { inchee. }\end{array}$ \\
\hline $1902 . a$ & & & & $\vec{v}$ & & \\
\hline January - .. - & 90 & 45 & 64 & 3,935 & 0.019 & 0.022 \\
\hline February ... & 70 & 41 & 60 & 3,332 & .018 & .019 \\
\hline March .... & 75 & 34 & 45 & 2,767 & .014 & .016 \\
\hline April ....... & 41 & 25 & 35 & 2,083 & .011 & .012 \\
\hline May ...... & 698 & 25 & 112 & 6,886 & .034 & .039 \\
\hline June . . . . . & 1,892 & 70 & 792 & 47,127 & .239 & .267 \\
\hline July ... . . . & 2,507 & 110 & 621 & 38,184 & .188 & .217 \\
\hline August ... & 1,910 & 100 & 512 & 31,482 & .155 & .179 \\
\hline September & 3,920 & 110 & 874 & 52,007 & .264 & .295 \\
\hline October .... & 3,920 & 364 & 1,089 & 66,960 & .329 & .379 \\
\hline November & 424 & 250 & 305 & 18,159 & .092 & .103 \\
\hline December. . . . & 275 & 190 & 234 & 14,388 & .071 & .082 \\
\hline The year & $3 ; 920$ & 25 & 395 & 287,310 & .120 & 1.630 \\
\hline 1903. & & & & & & \\
\hline January ..... & 240 & 180 & 205 & 12,605 & .062 & .071 \\
\hline February $\ldots .$. & 280 & 140 & 207 & 11,496 & .062 & .064 \\
\hline March ... & 1,336 & 210 & 628 & 38,614 & .190 & .220 \\
\hline April ... & 340 & 220 & 271 & 16,126 & .082 & .091 \\
\hline May ...... & $\tau, 580$ & 910 & 2,685 & 165,094 & .810 & .930 \\
\hline June . . . . . . & 7,895 & 835 & 2,873 & 170,955 & .870 & .970 \\
\hline July ..... & 985 & 332 & 533 & 32,773 & .160 & .180 \\
\hline Angust & 3,410 & 458 & 1,434 & 88,173 & .430 & .500 \\
\hline September .. & 472 & 207 & 322 & 19,799 & .097 & .108 \\
\hline October . . . . & 262 & 168 & 212 & 13,035 & .064 & 074 \\
\hline November . - & 304 & 168 & 223 & 13,270 & .067 & .075 \\
\hline
\end{tabular}

a Water-Sup. and Irr. Paper No. 84, U. S. Geol. Survey, 1903, p. 110.

The hydrograph for this stream at this station is shown on Pl. XIII, $A$. The mean monthly flow is seen to be very small, being only 20 second-feet in August, 1898. The maximum is very large, and usually occurs between May 1 and July 31. The monthly run-off per square mile varies from less than 0.01 to 0.87 second-foot. The yearly run-off per square mile varies from 0.03 to 0.120 second-foot for the years with complete record. The maximum monthly discharge is 143 times the minimum monthly discharge. 
SMOKY HILL RIVER AT ELLSWORTH, KANS.

The station on Smoky Hill River is at a highway bridge in Eilsworth. It was established April 17, 1895, and has been maintained continuously from that time to the present. The channel is about 180 feet wide at ordinary stage and nearly straight for 200 feet above and below the station. The bed is mainly sandy material and somewhat ehangeable. Velocity is moderate at ordinary stages. The surface fluctuations are read from the vertical gage bolted to one of the bridge piers.

The run-off results obtained at this station are given in the following table:

Estimated monthly discharge of Smoky Hill River at Ellsworth, Kans.

[Drainage area, 7,980 square miles.]

\begin{tabular}{|c|c|c|c|c|c|c|}
\hline \multirow[b]{2}{*}{ Month. } & \multicolumn{3}{|c|}{ Discharge in second-feet. } & \multirow[b]{2}{*}{$\begin{array}{c}\text { Total in acre- } \\
\text { feet. }\end{array}$} & \multicolumn{2}{|c|}{ Run-off. } \\
\hline & $\begin{array}{l}\text { Maxi- } \\
\text { mum. }\end{array}$ & $\begin{array}{l}\text { Mini- } \\
\text { mum. }\end{array}$ & Mean. & & $\begin{array}{c}\text { Second- } \\
\text { feet per } \\
\text { square } \\
\text { mile. }\end{array}$ & $\begin{array}{l}\text { Depth in } \\
\text { inches. }\end{array}$ \\
\hline 1895. $a$ & & & & & & \\
\hline April $1 \%-30^{-} \ldots \ldots$ & 14 & 11 & 12 & 336 & 0.002 & 0.001 \\
\hline May ....... & 20 & 9 & 11 & 676 & .001 & .001 \\
\hline June . . . . . . & 4,900 & 10 & 690 & 41,058 & .086 & .096 \\
\hline July . . . . . . & 21,000 & 202 & 1,438 & 88,420 & .180 & .208 \\
\hline August ........ & 344 & 65 & 186 & 11,437 & .023 & .027 \\
\hline September - . & 135 & 19 & 44 & 2,618 & .006 & .007 \\
\hline October & 22 & 14 & 18 & 1,107 & .002 & .003 \\
\hline November . .... & 19 & 12 & 18 & 1,071 & .002 & .003 \\
\hline December .... & 22 & 11 & 17 & 1,045 & .002 & .003 \\
\hline 1896. $a$ & & & & - & & \\
\hline January ....... & 57 & 17 & 25 & 1,537 & .003 & .004 \\
\hline February ..... & 49 & 18 & 26 & 1,496 & .003 & .004 \\
\hline March ....... & 21 & 14 & 18 & 1,107 & .002 & .002 \\
\hline April .. & 800 & 14 & 130 & 7,736 & .016 & .018 \\
\hline May ....... & 116 & 18 & 62 & 3,812 & .078 & .009 \\
\hline June . .... & 1,713 & $\tau^{2}$ & 313 & 18,625 & .039 & .044 \\
\hline July $\ldots \ldots$ & 951 & 119 & 230 & 14,142 & .029 & .033 \\
\hline August ....... & 372 & 66 & $\cdot 115$ & 7,071 & .014 & .016 \\
\hline September .... & 117 & 50 & 72 & 4,284 & .009 & .010 \\
\hline October ....... & 255 & 25 & 54 & 3,320 & .007 & .008 \\
\hline November . ... & 122 & 20 & 54 & 3,213 & .007 & .008 \\
\hline December ...... & 43 & 18 & 34 & 2,337 & .004 & .005 \\
\hline The year - & 1,713 & 14 & 95 & 68,680 & .012 & .161 \\
\hline
\end{tabular}

$a$ Eighteenth Ann. Rept. U. S. Geol. Survey, pt. 4, 1897, p. 214.

$\operatorname{IRR} 96-04-5$ 
Estimated monthly discharge of Smoky Hill River at Ellsworth, Kans.-Cont'd.

\begin{tabular}{|c|c|c|c|c|c|c|}
\hline \multirow[b]{2}{*}{ Month. } & \multicolumn{3}{|c|}{ Discharge in second-feet. } & \multirow[b]{2}{*}{$\begin{array}{l}\text { Total in acre- } \\
\text { feet. }\end{array}$} & \multicolumn{2}{|c|}{ Run-off. } \\
\hline & $\begin{array}{l}\text { Maxi- } \\
\text { mum. }\end{array}$ & $\begin{array}{l}\text { Mini- } \\
\text { mum. }\end{array}$ & Mean. & & $\begin{array}{l}\text { Second- } \\
\text { feet per } \\
\text { square } \\
\text { mile. }\end{array}$ & $\begin{array}{l}\text { Depth in } \\
\text { inches. }\end{array}$ \\
\hline$+\quad 1897 . a$ & & & & & & \\
\hline January $\ldots \ldots \ldots \ldots$ & 153 & 22 & 68 & 4,198 & 0.008 & 0.010 \\
\hline February .......... & 213 & 35 & 122 & 6,798 & .015 & .016 \\
\hline March & 77 & 22 & 35 & 2,164 & .004 & .005 \\
\hline April ....... & 385 & 35 & 158 & 9,401 & .020 & .022 \\
\hline May ....... & 385 & 87 & 173 & 10,624 & .022 & .025 \\
\hline June....... & 240 & 35 & 87 & 5,153 & .011 & .012 \\
\hline July ........ & 97 & 19 & 38 & 2,336 & .005 & .006 \\
\hline August ...... & 295 & 15 & 95 & 5,854 & .012 & .014 \\
\hline September & 130 & 15 & 40 & 2,386 & .005 & .006 \\
\hline October $\ldots \ldots$ & 97 & 10 & 32 & 1,949 & .004 & .005 \\
\hline November ..... & 27 & 15 & 38 & 2,285 & .005 & .005 \\
\hline December.... . & 107 & 19 & 38 & 2,337 & .005 & .006 \\
\hline The year.. & $38 \tilde{5}$ & 10 & 77 & 55,485 & .010 & .132 \\
\hline $1898 . b$ & & & & & & \\
\hline January ....... & 70 & 18 & 36 & 2,214 & .005 & .005 \\
\hline February . . . & 95 & 21 & 47 & 2,610 & .006 & .006 \\
\hline March ....... & 32 & 16 & 24 & 1,476 & .003 & .003 \\
\hline April ...... & 37 & 15 & 20 & 1,190 & .003 & .003 \\
\hline May ........ & 1,000 & 32 & 136 & 8,362 & .017 & .020 \\
\hline June & $\pi 17$ & 78 & 281 & 16,721 & .035 & .039 \\
\hline July ........ & 78 & 18 & 43 & 2,644 & .005 & .006 \\
\hline August ....... & 105 & 15 & 25 & 1,537 & .003 & .004 \\
\hline September .... & r63 & 14 & 131 & 7,795 & .016 & .018 \\
\hline October ....... & 55 & 18 & 30 & 1,845 & .004 & .004 \\
\hline November . . . & 42 & 18 & 19 & 1,131 & .002 & .003 \\
\hline December . . . . . & $14 \%$ & 24 & 53 & 3,259 & .006 & .007 \\
\hline The year .- & 1,000 & 14 & $r 0$ & 50,784 & .009 & .118 \\
\hline $1899 . c$ & & & & & & \\
\hline January .............. & 75 & $14^{\circ}$ & 44 & 2,705 & .0055 & .0063 \\
\hline February .............. & 84 & 42 & 63 & 3,499 & .0079 & .0082 \\
\hline March ......... & 75 & 19 & 40 & 2,460 & .0050 &, 0058 \\
\hline April $\ldots \ldots \ldots$ & 35 & 10 & 20 & 1,190 & .0025 & .0028 \\
\hline May $\ldots \ldots$ & 23 & 10 & 11 & 676 & .0014 & .0016 \\
\hline
\end{tabular}


Estimated monthly discharge of Smoky Hill River at Ellsworth, Kans.-Cont'd.

\begin{tabular}{|c|c|c|c|c|c|c|}
\hline \multirow[b]{2}{*}{ Month. } & \multicolumn{3}{|c|}{ Diseharge in second-feet. } & \multirow[b]{2}{*}{$\begin{array}{l}\text { Total in acre- } \\
\text { feet. }\end{array}$} & \multicolumn{2}{|c|}{ Run-off. } \\
\hline & $\begin{array}{l}\text { Maxi- } \\
\text { mum. }\end{array}$ & $\begin{array}{l}\text { Mini- } \\
\text { mum. }\end{array}$ & Mean. & & $\begin{array}{l}\text { Second- } \\
\text { feet per } \\
\text { square } \\
\text { mile. }\end{array}$ & $\begin{array}{l}\text { Depth in } \\
\text { inches. }\end{array}$ \\
\hline 1899. & & & & & & \\
\hline June ..... . & 3,890 & 10 & 492 & 29,276 & 0.0617 & 0.0688 \\
\hline July $\ldots \ldots$ & 7,947 & 56 & 832 & 51,158 & .1043 & .1202 \\
\hline August . & 862 & 42 & 152 & 9,846 & .0190 & .0219 \\
\hline September - & 75 & 19 & 46 & 2,737 & .0058 & .0064 \\
\hline October .... & 124 & 14 & 48 & 2,951 & .0060 & .0069 \\
\hline November. & 42 & 19 & 30 & 1,785 & .0038 & .0043 \\
\hline December .... & 35 & 19 & $2 \tau$ & 1,660 & .0034 & .0039 \\
\hline The year & 7,947 & 10 & 150 & 109,443 & .0189 & $.25 \% 1$ \\
\hline $1900 . a$ & & & & & & \\
\hline January $b$ & 97 & 40 & 49 & 3,013 & .006 & $.00 \%$ \\
\hline February $^{b}$ & $\ldots$ & $\ldots$ & 60 & 3,332 & .008 & .008 \\
\hline $\operatorname{March}^{b} \ldots$ & 183 & 40 & 66 & 4,058 & .008 & .009 \\
\hline April $\ldots \ldots$ & 594 & 35 & 156 & 9,283 & .020 & .022 \\
\hline May ...... & 660 & 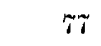 & 147 & 9,039 & .018 & .021 \\
\hline June & 616 & $8 \pi$ & 241 & 14,340 & .030 & .083 \\
\hline July _. . - & 705 & 35 & 117 & $r, 194$ & .015 & .017 \\
\hline August ... & 97 & 18 & 47 & 2,890 & .006 & .007 \\
\hline September .... & 616 & 18 & 140 & 8,331 & .018 & .020 \\
\hline October . ..... & 144 & 40 & 78 & 4,796 & .010 & .012 \\
\hline November..... & 40 & 22 & 28 & 1,666 & .004 & .004 \\
\hline December ..... & 26 & 18 & 21 & 1,291 & .003 & .003 \\
\hline The year & $\ldots$ & - - & 96 & 69,283 & .012 & .163 \\
\hline $1901 . c$ & & & & & & \\
\hline January ........ & 120 & 18 & 50 & $3,0 \% 4$ & .006 & .007 \\
\hline February .. & 165 & 20 & ro & 3,999 & .009 & .009 \\
\hline March ... & 50 & 20 & 33 & 2,029 & .004 & .005 \\
\hline April & 662 & 23 & 124 & 7,378 & .016 & .018 \\
\hline May .... & 81 & 23 & 47 & 2,890 & .006 & $.00 \%$ \\
\hline June .... & 142 & 23 & 48 & 2,856 & .006 & .007 \\
\hline July _.......... & 18 & 5 & 9 & 553 & $\ldots 001$ & $.0) 1$ \\
\hline August _...... & $14 ?$ & 5 & 46 & $2,828^{\prime}$ & .006 & .007 \\
\hline September ..... & 142 & 12 & 62 & 3,689 & .008 & .009 \\
\hline
\end{tabular}

a Twenty-second Ann. Rept. U. S. Geol. Survey, pt. 4, 1902 , p. 336.

$b$ Approximate.

$c$ Water-Sup. and Irr. Paper No. 75, U. S. Geol. Survey, 1903, p. 143. 
Estimated monthly discharge of Smoky Hill River at Ellsworth, Kans._Cont'd.

\begin{tabular}{|c|c|c|c|c|c|c|}
\hline \multirow[b]{2}{*}{ Month. } & \multicolumn{3}{|c|}{ Discharge in second-feet. } & \multirow[b]{2}{*}{$\begin{array}{l}\text { Total in acre- } \\
\text { feet. }\end{array}$} & \multicolumn{2}{|c|}{ Run-off. } \\
\hline & $\begin{array}{l}\text { Maxi- } \\
\text { mum. }\end{array}$ & $\begin{array}{l}\text { Mini. } \\
\text { mum. }\end{array}$ & Mean. & & $\begin{array}{l}\text { Second- } \\
\text { feet per } \\
\text { square } \\
\text { mile. }\end{array}$ & $\begin{array}{l}\text { Depth in } \\
\text { inches. }\end{array}$ \\
\hline 1901. & & & & & & \\
\hline October . . ..... & 73 & 14 & 36 & 2,214 & 0.005 & 0.006 \\
\hline November.... & 14 & 8 & 11 & 655 & .001 & .001 \\
\hline December ... & 50 & 12 & 22 & 1,353 & .003 & .003 \\
\hline The year & 652 & 5 & 47 & 33,518 & .006 & .080 \\
\hline 1902. $a$ & & & & & & \\
\hline January ...... & 55 & 17 & 24 & 1,475 & .003 & .003 \\
\hline February -. & 100 & 17 & 38 & 2,110 & .005 & .005 \\
\hline March ..... & 290 & 19 & 39 & 2,398 & .005 & .006 \\
\hline April ...... & 23 & 15 & 18 & 1,071 & .002 & .002 \\
\hline May . . . . . & 700 & 13 & 87 & 5,349 & .011 & .013 \\
\hline June . . . . . & 4,856 & 40 & 821 & 48,853 & .103 & .115 \\
\hline July ....... & 3,267 & 137 & 891 & 54,785 & .112 & .129 \\
\hline Àugust $\ldots . .$. & 7,375 & 62 & 1,021 & 62,779 & .128 & .148 \\
\hline September - & 7,840 & 100 & 1,033 & 61,468 & .130 & .144 \\
\hline October ...... & 1,390 & 187 & 588 & 36,155 & .074 & .085 \\
\hline November. . . & 187 & 62 & 125 & 7,438 & .016 & .017 \\
\hline December ... & 85 & 40 & 64 & 3,935 & .008 & .009 \\
\hline The year - & 7,840 & 13 & 396 & 287,816 & .050 & .676 \\
\hline 1903. & & & & & & \\
\hline January . . . . . & 131 & 50 & 69 & 4,243 & .0086 & .0099 \\
\hline February & 110 & 50 & 65 & 3,610 & .0081 & .0084 \\
\hline March & $1, \pm 10$ & 62 & 431 & 26,501 & .0340 & .0620 \\
\hline April... & 1,834 & 62 & 182 & 10,830 & .0230 & .0260 \\
\hline May ... & 11,392 & 510 & 2,356 & 144,865 & .3000 & .3400 \\
\hline June . . & 3,750 & 342 & 937 & 55,755 & .1200 & .1300 \\
\hline July _... & 305 & 120 & 180 & 11,068 & .2300 & .2600 \\
\hline August_... & 2,708 & 155 & 735 & 45,193 & .0920 & .1100 \\
\hline September & 143 & 50 & 81 & 4,820 & .0100 & .0110 \\
\hline October & 92 & 45 & 58 & 3,566 & .0073 & .0084 \\
\hline November...:- & 120 & 45 & 70 & 4,304 & .0088 & .0098 \\
\hline December & 92 & 36 & 44 & 2,705 & .0055 & .0063 \\
\hline The year & 11,392 & 36 & 434 & 317,460 & .0723 & .9818 \\
\hline
\end{tabular}

$a$ Water-Sup. and Irr. Paper No. 84, U. S. Geol. Survey, 1903, p. 112. 
The hydrograph of this stream at this station is shown on PI. XIII, C. The minimum monthly flow is seen to have been less than 10 secondfeet during July, 1901. The maximum discharge was 1,438 secondfeet in July, 1895, which is 160 times the minimum monthly discharge. The monthly run-off per square mile varies from less than 0.001 to 0.18 , and the yearly run-off from 0.006 to 0.050 second-feet.

\section{COMPARISON OF FLOOD AND ORDINARY DATA.}

In the following table is given a comparison of the ordinary low flow with the flood flow of these streams. The flood flow is seen to be many times larger than the ordinary low-water flow.

Low-water and flood-flow data of streams in Kansas River basin.

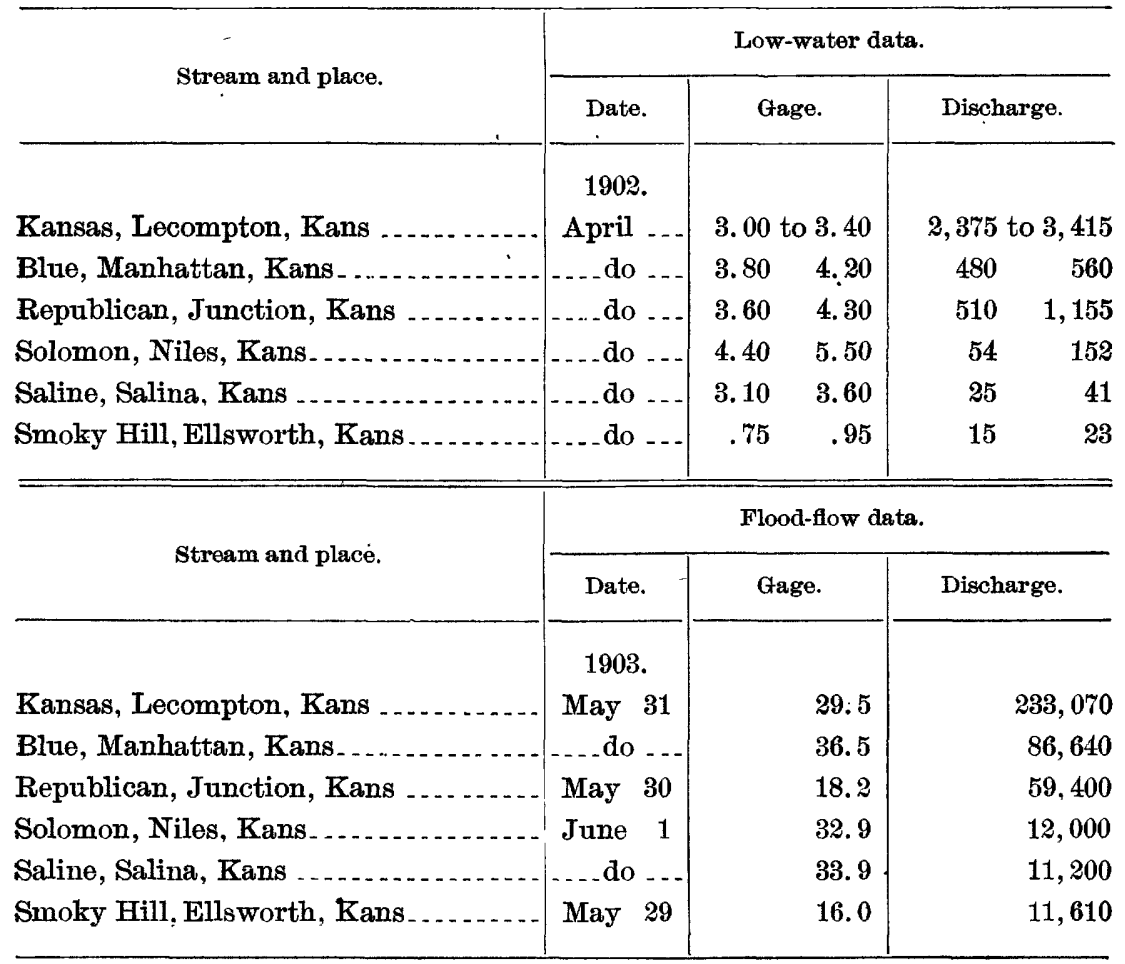

The following table gives a comparison of the discharges at the six gaging stations and also the run-off for four months of 1903. The stations are arranged in order from the west to the east. The increase in run-off from the west to the east is clearly shown. 
Comparisons of monthly discharge and run-off at gaging stations in Kansas River watershed.

MONTH OF APRIL, 1902.

\begin{tabular}{|c|c|c|c|c|c|c|}
\hline \multirow[b]{2}{*}{ Stream and place. } & \multicolumn{3}{|c|}{ Discharge in second-feet. } & \multirow[b]{2}{*}{$\begin{array}{c}\text { Total in } \\
\text { acre-feet. }\end{array}$} & \multicolumn{2}{|c|}{ Run-off. } \\
\hline & $\begin{array}{l}\text { Maxi- } \\
\text { mum. }\end{array}$ & $\begin{array}{l}\text { Mini- } \\
\text { mum. }\end{array}$ & Mean. & & $\begin{array}{l}\text { Second- } \\
\text { feet per } \\
\text { square } \\
\text { mile. }\end{array}$ & $\begin{array}{l}\text { Depth in } \\
\text { inches. }\end{array}$ \\
\hline Smoky Hill, Ellsworth, Kans . . ......... & 23 & 15 & 18 & $1,0 \pi 1$ & 0.002 & 0.002 \\
\hline Saline, Salina, Kans $\ldots \ldots$ & 41 & 25 & 35 & 2,083 & .01 & .01 \\
\hline Solomon, Niles, Kans & 152 & 54 & 89 & 5,296 & .01 & .01 \\
\hline Republican, Junction, Kans & $1,20 \%$ & 510 & 654 & 38,916 & .03 & .03 \\
\hline Republican, Superior, Nebr . . . ........... & $\tau 40$ & 390 & 555 & 33,020 & .02 & .02 \\
\hline Blue, Manhattan, Kans . .................. & 560 & 408 & 483 & 28,740 & .05 & .06 \\
\hline Kansas, Lecompton, Kans $\ldots . .$. & 3,415 & 2,250 & 2,653 & 157,864 & .05 & .06 \\
\hline
\end{tabular}

MONTH OF MAY, 1902 .

\begin{tabular}{|c|c|c|c|c|c|c|}
\hline Smoky Hill, Ellsworth, Kans . . . . . . . . . & 700 & 13 & $8 i$ & 5,349 & 0.011 & 0.013 \\
\hline 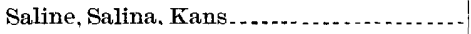 & 698 & 25 & 112 & 6,886 & .034 & .089 \\
\hline Solomon, Niles, Kans & 1.415 & 38 & 285 & 17,524 & .04 & .05 \\
\hline Republican, Junction, Kans ............... & 7.800 & 489 & 2,128 & 130,846 & .08 & .09 \\
\hline Republican, Superior, Nebr $\ldots . .$. & 2.810 & 335 & 1,269 & ז8,020 & .06 & .07 \\
\hline Blue, Manhattan, Kans . . . . . . . & 17,510 & 408 & 2,157 & 139,629 & .23 & .27 \\
\hline Kansas, Lecompton, Kans ......... & $93,0 \pi 5$ & 2,125 & 8,435 & 518,648 & .14 & .16 \\
\hline
\end{tabular}

MONTH OF JUNE, 1902

\begin{tabular}{|c|c|c|c|c|c|c|}
\hline Smoky Hill, Ellsworth, Kans . . . . . . . . & 4,856 & 40 & $8: 21$ & 48,853 & 0.10 & 0.12 \\
\hline Saline, Salina, Kans $\ldots \ldots \ldots$ & $1,89: 3$ & \%0 & 792 & 4,127 & .24 & .27 \\
\hline Solomon, Niles, Kans ............ & 6,155 & 316 & 1,392 & 82,830 & .20 & .22 \\
\hline Republican, Junction, Kans .............. & 8.400 & 1,260 & 3,338 & 198,625 & .13 & .15 \\
\hline Republican, Superior, Nebr ................. & 3,935 & $3: 0$ & $1,3 \%$ & 81,640 & .06 & $.0 i$ \\
\hline Blue, Manhattan, Kans . . . . . . . . . . . . & 17,510 & 910 & 6,298 & 374,757 & .66 & .74 \\
\hline Kansas, Lecompton, Kans $\ldots \ldots \ldots$ & 28,500 & 11,110 & 17,131 & $1,019,365$ & .29 & .320 \\
\hline
\end{tabular}

MONTH OF JULY, 1902

\begin{tabular}{|c|c|c|c|c|c|c|}
\hline Smoky Hill, Ellsworth, Kaus ............. & 3,267 & 137 & 891 & 54,785 & 0.112 & $0.1,39$ \\
\hline Saline, Salina, Kans. & 2,507 & 110 & $6 \% 1$ & 38,184 & .188 & .217 \\
\hline 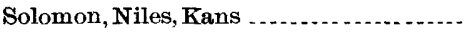 & 7,040 & 252 & 2,492 & 153,227 & .37 & .43 \\
\hline Republican, Junction, Kans ................ & 23,100 & 840 & $7,88 i$ & 484,953 & .30 & .35 \\
\hline Republican, Superiol', Nebr $\ldots . . . . . .$. & 12,490 & $9 \% 0$ & a 3,080 & - $a 189,360$ & a. 14 & a. 16 \\
\hline 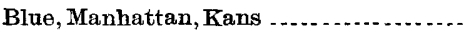 & 43,430 & 4,540 & $16,8 \in 6$ & $1,087,050$ & 1.78 & 2.05 \\
\hline 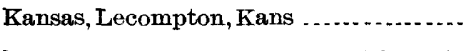 & 81,400 & 11,450 & 38,291 & $2,354,422$ & .65 & .75 \\
\hline
\end{tabular}

\section{METHODS FOR PREVENTING DAMAGE BY FUTURE FLOODS.}

It must be remembered that the storm that caused the flood on Kansas River was not a local one of short duration, but extended over a considerable portion of six States and Territories and lasted nearly half a month. The storm was brought about by a rare combination of atmospheric pressure, temperature, moisture, and wind 
velocity. Each of these was practically at or near its maximum influence at the time. There is no reason why this combination of rainfall factors may not occur again, and when it does occur a storm of approximately the same magnitude may be expected. Nothing whatever can be done to prevent its occurrence. It is sixty years since the last great flood, but there is no way of predicting when the next one will occur.

Although nothing can be done to prevent the occurrence of such a storm, much can be done to lessen the height of the resulting flood and the loss of property due to it. It is self-evident that to reduce the magnitude of a flood we must in some way either store the water that falls or hasten its flow from the drainage area, or both.

\section{SURFACE AND GROUND STORAGE.}

Nature has two ways of storing water, viz, on the surface of the ground and in the ground. In mountain regions water is stored for several months as snow and ice, and in the early summer passes down the streams. In regions of higher temperature surface water is stored in lakes, ponds, and swamps. Where streams are fed from mountain snow or lakes the distribution of flow throughout the year is very different from that of streams without surface storage. Surface storage in some sections of the country is vastly greater than that in others. In Maine, for example, there is 1 square mile of lake and pond area to every 14.3 square miles of land area. In other words, 7 per cent of the surface is natural water storage. On the prairies of the Kansas River watershed the natural surface storage is so small that it amounts practically to nothing.

EFFECT OF GROUND STORAGE ON' FLOW OF STREAMS.

A rainfall of a depth of, say, 2 inches on a watershed disappears in three ways. A part flows over the surface and forms what is called surface run-off. A second part evaporates, thus passing off unseen from the surface of the ground and from pools of water. A third part sinks into the ground and is held for a greater or less time, but eventually is either absorbed by vegetation and passes off into the air through leaves or percolates through the ground into the streams. The total run-off-that which is left of the rainfall after the loss by evaporation and plant growth-varies from about 50 per cent in the eastern part of the country to almost nothing in the arid portions.

The amount of water that the soil will hold when saturated or full, depends on its porosity and depth. Let us suppose that the ground at a certain place is composed of a 6 -foot layer of sand whose porosity is $33 \frac{1}{3}$ per cent. Each foot in depth of this material will contain, when fully saturated, 4 inches of water, and the 6-foot layer will contain 2 feet depth of water. It will rarely be possible to store, even in sand, this amount of water, because it is seldom empty. It always holds back or contains some water. 
miles. The ratio of 455,348 to $5 S, 550$ shows the average number of acre-feet of water flowing on May 31 from each square mile of the whole drainage of Kansas River. In other words, if there had been a storage reservoir 1 acre in area and 7.8 feet deep on every square mile of the whole Kansas River drainage basin the water flowing down Kansas River on May 31 would have filled every one of them. If on each half section of the whole of the Kansas River basin there had been a reservoir 1 acre in extent and 4 feet in depth the water flowing in Kansas River on May 31 would have been sufficient to nearly fill each one of them.

\section{RAPID REMOVAL OF WATER.}

Water that can not be lield back for some days by storage should be passed out of the watershed as rapidly as possible if the danger of floods is to be reduced to a minimum. Anything that retards the flow backs up the water and causes a rise in the river and consequent overflow of area.

Dams and river bends have a decided retarding effect. The water has a longer distance to travel by reason of the bends and thus a longer time is necessary for it to pass out of the watershed, and the velocity of the water is reduced by striking the bank at each bend.

Bridges across a stream are sometimes a very fruitful cause of increasing high water. They restrict both the width and depth of the waterway. The partial or total destruction of nearly all the bridges across Kansas River is very positive evidence of this fact. The Engineering News of September 17, 1903, contains the following in regard to the restriction in width of Kansas River at Kansas City:

The Kaw [Kansas] River near the mouth has been gradually encroached upon for years, the abutting property owners filling in and reclaiming the land for ind ustrial purposes. The normal width of the river from bank to bank is about 800 feet. At the James street bridge, just above the mouth, this channel has been narrowed down to about 450 feet between abutments. The effect of this construction is also shown by the fact that the high-water mark at the-Turkey Creek pumping station, about 2 miles above the mouth of the river, was 10 feet above that at the mouth. If the river had been given its natural width through the city, the water would not have risen so high by from 6 to 8 feet in the upper districts as it did nnder the existing conditions. It is evident that the clear channel of the Kaw should be made from 800 to 1,000 feet wide from Argentine to the Missouri River.

A channel 200 feet wide was cut around the north end of the bridge at Lawrence by the flood. This channel is being closed by an embankment. The closing of this opening by a solid structure, thus reducing the waterway to its old dimensions, which the flood has shown to be too small, is ignoring one of the obvious lessons of the flood. It would have been better to have bailt a structure here with gates for holding back the water for power purposes, which could have been opened in time of flood to give a larger waterway. 
The masonry arch bridge across the Kansas at Topeka is a good example of the evil resulting from restricting too much the waterway. The flood passed several feet in depth over both abutments of this bridge, washing out one of them and badly damaging the bridge and the other abutment. The old bridge at this place had six spans of 150 feet each; the present masonry structure has reduced the waterway nearly one-half, and has had much to do with the overflow at Topeka. There are several new bridges across the Kansas that restrict its flow much more than the old ones. The small saving in the cost of a bridge by reducing its length 100 feet is paid many times over in the loss of property caused by the overflow due to restricting the waterway. A very obvious means of reducing the height of future floods is to widen the channel in the cities through which the river passes. The minimum width and the number and size of bridge piers should be prescribed by law.

This flood has shown that many of the bridges across Kansas River before the flood were too low. The new ones should be higher than the old ones or of a design such that the bridge can be raised or swung out of the way during very high water and leave a clear channel for drift to pass.

CUT-OFFS AND OVERFLOW CHANNELS.

The effect of a cut-off is to shorten the distance traveled by the water, to reduce the loss of head due to friction, to increase the velocity of flow, and thus to reduce the height of the flood. If the bed and banks are composed of firm material that will not be worn away by the current, this plan works well, but for rivers flowing through alluviąl material, such as Mississippi, lower Missouri, and Kansas rivers, this remedy is only temporary. The increased velocity will cause additional scours and the formation of new bends. Thus this process will continue until the river is restored to its former length. The studies of Humphrey and Abbott, and other engineers, of the Mississippi prove conclusively that this plan is not a good one for rivers flowing through alluvial bottoms.

Overflow channels increase the high-water waterway of the river and thus reduce the height of flood. They are equivalent to widening the main channel. Increasing the area of the main channel for a given amount, say 1,000 square feet, is, as a rule, more effective than one or more overflow channels of the came total area.

\section{LEVEES.}

Levees are proposed as a remedy for floods. This method is nsed on the Mississippi for securing the land against inundation. It was begun in 1717 at New Orleans by riparian owners and carried on until 1850 by the States through which the river passes. Since this date levee building has been carried on by cooperation of the state and National governments. All of the engineers who have made a 
study of methods of preventing floods in the Mississippi basin recommend this as the only feasible method of accomplishing the desired result. The levees or earth banks on each side of the river approximately parallel to the course of the stream, limit the width of the stream, increase somewhat the velocity and consequent scour, and the height of high water.

Three objections are raised to the use of levees: First. That they can not be made strong enough. Second. The cost is too great. Third. They raise the bed of the river by depositing in it the silt that otherwise would be deposited on the flooded land.

It is difficult to see how the third objection can be true. The increased velocity will cause a scour rather than a deposit of material on the bed. Furthermore, a careful study of the effect of the levees along Mississippi River fails to show any appreciable rise in the bed of that river.

The numerous and frequent breaks in the levees during the floods apparently show that there may be some truth in the first objection. This is only apparent, however, as earth embankments can be made so strong and durable that they will not fail and so high that the greatest floods can not pass over them. Many earth dams and embankments have been built much higher than any of the levees and have stood the test of many years. The strength and durability of such a structure is only a matter of cost.

Whether or not the levee method of preventing inundation of the Kansas River bottom is feasible can be definitely decided when the cost and benefits to be derived are known. Ordinary floods cause overflow of some of the bottom lands along the river. The flood of 1903 was 17 feet higher than ordinary floods, so that the levee will need to be 20 feet high in some places. The cost per mile in length of an embankment of this height, with a top width of 5 feet and side slopes of 2 horizontal and 1 vertical, will be as follows, assuming the cost to be 20 cents per cubic yard:

$$
\frac{900 \times 5280}{27} \times .20=\$ 35,200 .
$$

If the embankment is only 10 feet high, 3 feet top width, side slopes of 2 horizontal to 1 vertical and the cost per cubic yard 20 cents, the total cost per mile of the embankment will be $\$ 8,993$.

The benefits to be derived will scarcely justify either of these expenditures except at or near cities.

SUMMARY.

The highest recorded flood at St. Louis occurred in 1785 . The flood of 1844 came within 1 foot of the height reached in 1785, and the flood of 1903 came within about 3 feet of the stage of 1785 .

The highest flood on record at Kansas City was in 1844. The flood 
of 1903 , although it did not reach that height, was vastly more destructive on account of the country being more thickly settled and improved.

The Kansas River gage records at Lawrence and Lecompton cover a period of twenty-two years. The flood of May and June, 1903, was $17 \frac{1}{2}$ feet higher than at any other time within this period. The volume flowing in Kansas River on May 31 was nearly three and a half times larger than that at any time during these twenty-two years.

The period of excessive rainfall extended from May 16 to May 31. Water fell to a depth of 10 inches in some places during this time. The rainfall at some of the stations for the whole month of May was 17 inches, so that the precipitation for the first half was above the normal, the ground was well supplied with moisture, and the flow of the streams was above the normal. The mean annual rainfall of the Kansas River basin varies from about $3 \check{5}$ inches in the eastern part to 12 inches in the western part. About 14 per cent of this mean annual rain falls in May, but in May, 1903, nearly 50 per cent of the mean annual rainfall occurred.

The drainage area of Kansas River is a long narrow strip between the Platte and the Arkansas River drainage areas. It is rolling prairie without mountains, with broad, shallow valleys, fertile soil, and very little forest. There is very little service storage, but the ground will absorb a large quantity of water. The flood flow of the stream is large and the minimum flow small, as compared with streams in the eastern half of the United States.

The Kansas River bottom is mainly sandy, allnvial material from 1 to 4 miles in width; the banks as a rule are not more than 10 feet in height and are easily eroded by the current.

For eleven days, May 28 to June 7, inclusive, the water was from 1 to 12 feet higher at Lecompton than it had been before in twenty-two years; and for twenty days, May 23 to June 11, it was from half a foot to $17 \frac{1}{2}$ feet higher than ordinary high water. The whole river bottom was flooded, crops were destroyed, stock drowned and swept away; railroads were under water, partly washed away and undermined; wooden buildings were lifted from their foundations and swept down the stream; brick and stone buildings crumbled and fell; bridges were swept away and cities left without drinking water, light, or power; traffic was almost entirely suspended for two weeks. The property loss in Kansas and Kansas City is estimated to have been $\$ 22,000,000$.

Nothing can be done to prevent the recurrence of a storm like the one from May 16 to 31, 1903, which caused this enormous loss, and no person can predict the time of occurrence of the next one.

To reduce the magnitude of the resulting flood, the rainfall must quickly be passed out of the watershed or-stored in it. The opportunities for surface storage in the Kansas River basin are small, for the 
valleys and depressions are broad and shallow, the amount that can be stored small, and the cost of storage large. On the headwaters, where the possibility of storage is greatest, the rainfall is smallest. By a glance at the map it will be seen that nearly all of the rain that caused this flood fell on the lower half of the watershed, where the possibilities for surface storage are the least.

If there had been a reserroir 1 acre in extent and 4 feet in depth on each half section of land in the whole Kansas River basin, the volume of water flowing down Kansas River on May 31 was sufficient to have nearly filled all of them.

Ground storage in the Kansas River basin is large; it can be increased by cultivation of the soil and growth of forests. Not more than 7 per cent of the rainfall on this drainage area appears as runoff in ordinary years; the remaining 93 per cent disappears as evaporation directly from the surface and indirectly through plant growth.

Any obstruction in the form of a dam, bend in the channel, or reduction of the normal width retards the flow and increases the magnitude of a flood. The partial destruction of nearly all the bridges across Kansas River is positive evidence that they restricted the flow too much. The normal width of Kansas River at Kansas City has been reduced nearly one-half, and as a result the recent flood was about 10 feet lower at the mouth than about 2 miles up from the mouth.

Reducing the length of the channel by straightening it will reduce the magnitude of the flood, but in alluvial bottom land the increased velocity causes scour and the formation of new beds, so the remedy is only temporary.

Overflow channels give an additional waterway and reduce the height of floods, but are seldom practicable.

Levees have proved to be the best means of preventing inundation in the Mississippi River basin; they do not reduce the height of floods, but simply prevent overflow. The cost of levees sufficiently high and durable to prevent overflow of the Kansas River bottom during a flood of the magnitude of that of 1903 would be too expensive to build except in and near cities. 


\section{N D E X.}

Page.

Alston, S. C., stream measurements at .....

Argentine, Kans., view of bridge in, after flood.

Asheville, N, C., rainfall at...............

Balm Creek, Oregon, discharge of .........

Barksdale, s. C., rainfall at ...............

Beloit, Kans., gaging station at ............ stream measurements near............

Benkelman, Nebr., gaging stations at and near

stream measurements near..

Beverly, Kans., gaging station at .......... stream measurementsat.

Bismarck, N. Dak., rainfall at........... 23,24

Blue River, comparison of low-water and flood-water data of..............

drainage area of........................

hydrographs of

measurements of, near Manhattan, Kans ................. 36, 43-47,70

Bowersock, J. D., gaging station at Lawrence, Kans., established by....

Brevard, N. C., rainfall at.

Bridges, restriction by, of width and depth of streams

.. 74-75

Broad River, measurements of, at Alston, S. C

Charlotte, N. C., rainfall at.

Cheyenne, Wyo., rainfall at.............. 23, 24

Clifton, views of, before and after the flood, plate showing............

Clifton mills, destruction of, account of . 16-18

Columbia, s. C., rainfall at............... 14

Concordia, Kans., rainfall at............. 23, 24

Cut-offs, effect of, on flow of streams...... 75

Dams, effect of, on flow of streams........ 74

Davenport, Iowa, rainfall at ............ 23, 24

Denver, Colo., rainfall at................23,24

Des Moines, Jowa, rainfall at............ 23,24

Destruction wrought by Heppner flood....

Destruction wrought by Kansas flood...... 30-32

Destruction wrought by South Carolina flood .......................... 16-18

Dodge, Kans., rainfall at................... 23,24

Drane, B. S., acknowledgments to.......... quoted on destruction of Clifton mills... 16-18

Dubuque, Iowa, rainfall at..............23, 24

Ellsworth, Kans., Smoky Hill River at, comparison of low-water and floodwater data of.

Smoky Hill River at graging atation on. hydnograph of..................... measurements of ..

$35,65-70$

Englemann, George, eited on floods on the Mississippi at St. Louis
Enoree River, high-water mark on......... 16

Fingerville, S. C., high-water mark at...... 16

Floods, methods for preventing damage by . 70-76 See Heppner flood; South Carolina flood; Kansas flood.

"Flow-line" bridge, view of, as repaired .. 30

Fort Smith, Ark., rainfall at............ 23, 24

Fort Worth, Tex., rainfall at............. 23,24

Gaffney, s. C., rainfall at............... 14

Greenville, S. C., rainfall at............... 14

Ground and surface storage of water, effect of, on flow of streams.......... 71-74

Hannibal, Mo., rainfall at................ 23,24

Heath Springs, S. C., rainfall at.......... 14

Hendersonville, N. C., rainfall at......... 14

Henrietta, N. C., rainfall at ............. 14

Henry, A. J., cited on rainfall in South Carolina...................... 14

Heppner, destruction of................. 12

Heppner flood, causes of................. 9-10

description of ....................... 11-12

duration of ....................... 9-10,11

effect of $\ldots \ldots \ldots \ldots \ldots \ldots \ldots \ldots \ldots \ldots \ldots \ldots, 12$

height of $\ldots \ldots \ldots \ldots \ldots \ldots \ldots \ldots \ldots \ldots, \quad 11$

information concerning, sources of..... 10

lessons taught by ..................., 12

loss of life and property due to........ 9,12

Highlands, N. C., rainfall at............... 14

Hinton Creek, Oregon, flood in........... $\quad 12$

Hoyt, J.C., acknow ledgments to........... 9

Huron, S. Dak., rainfall at ................ 23,24

Journal of Agriculture, quoted on the flood at $\mathrm{St}$. Louis ...................

Junction, Kans., Republican River at, comparison of low-water and floodwater data of

(1)................ 69 hydrograph of.................. 52 measurements of ............ 35,48-51,70

Kansas, map of adjacent States and........ 24 map of, showing mean annual rainfall lines......................... 25

Kansas City, flood in the vicinity of.... 29, 80-82 flood records at .................. 20,76-77

Kansas City Southern Railway bridge at, view of, after flood.......... $\quad 34$

map of, showing flooded area ......... $\quad 32$

Missouri Pacific Railway bridge at, view of, after the flood............... 30

rainfall at ............................ 23,24

Kansas City Southern Railway bridge, Kansas City, view of, after flood ....

Kansas City Times quoted on the flood in Kansas City....................

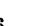

6




\section{LIBRARY CATALOGUE SLIPS.}

[Mount each slip upon a separate card, placing the subject at the top of the second slip. The name of the series should not be repeated on the series card, but the additional numbers should be added, as received, to the first entry.]

\section{Murphy, E[dward] C[harles]}

... Destructive floods in the United States in Igo3, by E. C. Murphy. Washington, Gov't print. off., I904.

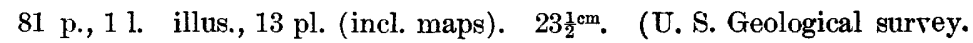
Water-supply and irrigation paper no. 96.)

Subject series M, General hydrographic investigations, 11.

Contents.-Heppner, Oreg., flood.-South Carolina flood.-Notes on early floods in the Mississippi valley.-Kansas floods and hydrographic data.

\section{Murphy, E[dward] C[harles]}

... Destructive floods in the United States in I903, by E. C. Murphy. Washington, Gov't print. off., r904.

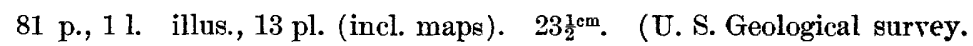
Water-supply and irrigation paper no. 96.)

Subject series M, General hydrographic investigations, 11 .

Contents.-Heppner, Oreg., flood.-South Carolina flood.-Notes on early floods in the Mississippi valley.-Kansas floods and hydrographic data.

\section{U. S. Geological survey.}

Water-supply and irrigation papers.

no. 96. Murphy, E. C. Destructive floods in the United States in 1903. I904.

\section{U. S. Dept. of the Interior.}

see also

U. S. Geological survey. 


\section{Serites K-PUMPTMg WatwR.}

WS 1. Pumping wroter for irrigation, by H. M. Wilson. $1890.55 \mathrm{pp}, 9$ pls.

WS 8. Windrnills for irrigation, by E. C. Murphy. $189 \%$. 49 pp., 8 pls,

WS14. New tests of certain purmps and water lifts uend in irrigation, by O. P. Hood. 1898. $21 \mathrm{pp}, \mathrm{l} \mathrm{pl}$.

WS 20. Experiments with windmills, by T. O. Perry. 1890.97 pp., 12 pls.

WS 29 . Wells and windmills in Nebraska, by E. H. Barbour, $1899.85 \mathrm{pp}, 27 \mathrm{pls}$.

WS 41. The windmill; its efficiency and economic use, Pt, I, by E, C, Murphy. 1901. 72 pp. 14 pls.

WS 42. The windinill, Pt. II (continuation of No. 41). $1901.73-147 \mathrm{pp}, 15-16 \mathrm{pl}$.

WS 91. Natural features and monomic development of Sandusky, Dianmee, Muskingum, and Miami drainage areas in Ohio, hy B. H. Flynn and M. S. Flynn. $1904.130 \mathrm{pr}$.

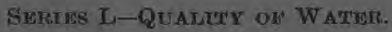

WS 3. Sewage irrigation, by G. W. Rafter. 1897 . 100 pe., 4 pls.

WS.22. Sewage irrigntion, Pt. IT, by G. W. Rafter. 1899.100 pp., i pls.

WS $7 \%$. Sewage pollution neat New Xork City, by M. O. Leighton. 1903. ra jp., 8 gls.

WS 76. Observations on flow of rivers in the vicinity of New York City, by H. A. Preggay. 19013. $108 \mathrm{pp}, 13 \mathrm{pls}$.

Ws 79. Normal and polluted vaters in northeastern United Statos, by M. O. Leighton. 1908. $192 \mathrm{pp} ., 15 \mathrm{pls}$.

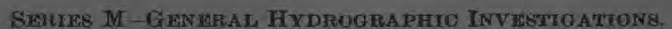

WS 56. Mothorts of stream measurement. $1001.51 \mathrm{pp}$. $12 \mathrm{pls}$.

WS 64. Accuracy of stream measurements, by E. C. Murphy. 1902. 99 pp., 4 pls.

WS 76. Observations on the flow of rivers in the vicinity of New Yark City, by H. A. Preney. 1903. $105 \mathrm{pp}, 13 \mathrm{pls}$.

WS 80. The relation of rainfall to run-off, by G. W. Rafter. 1903. $104 \mathrm{pp}$.

WS 81. Californir hydrogrephy, hy J. B. Lippincott. $1903,488 \mathrm{pD} / \mathrm{pl}$.

WS 88, The Passaic fload of 1902, by G. B. Hollister and M. O. Leighton. 1903. 56 ppo, 15 pls

WS 91. Natural features and esonomic development of Sanausky, Maumee, Muskingum, and Miami drainage areas in Ohio, by B. F. Flynn and M. S. Flynn. 1904. 130 pp.

WS 12, The Passatic flood of 1908 , by M. O. Leighton. 1904. $48 \mathrm{pg}$. $7 \mathrm{pIs}$.

WS 94. Hydrographic manual of the United States Geological Survey, prepared liy If. C. Mur: phy, J. C. Foyt, and G. B, Hollister. $1924.76 \mathrm{pp}, 3 \mathrm{pls}$.

WS 95. Aceuracy of stream measurements (stecond edition), by E. C. Murphy. 1904 - pp.. 6 puls.

WS 96. Destructive floods in the United States in 1908 , by E. C. Murpliy. $1972 . \quad-$ Pp., 13 pls.

\section{SERMEA N-WATWR POWER.}

WS 24. Water resources of State of New York, Pt. I, by G. W. Rafter. 1899. 92 pp., 18 pls.

Ws 25. Water resources of State of New York, Pt. XI, by G. W. Ruaftex, 1809.1 100-2ki pp., 12 pls. WS 44. Profiles of rivers, by Henry Gannett. $1901.100 \mathrm{pp} \cdot 11 \mathrm{pls}$.

WS 62. Hydrogrephy of the Southern Appalachian Mountain rngion, Pt. I, by H. A. Pressey1902. $95 \mathrm{pp}, 25$ pls.

WS 63, Hydrography of the Southern Appalachian Mountain region, Pt. U, by H. A. Pressey.

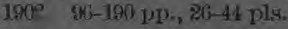

WS 69. Water powers of the State of Maine, by H. A. Pressey. 19u2. 121 p1., 14 ply.

Iux. $96-3$

[Continked on fokrth page of cover.] 


\section{SERTES O-UNDREGROUNO WATERS.}

WS 4. A reconna issnnco in southesstern Wrahington, by I. C. Russell. 189?. 96 1p., 7 pls.

WS 6. Underground waters of southwestern Kansas, by Erasmus Haworth. 1995. 65 pp. 12 pls.

WS 7. Seepage watens of northern Utah, by Samuel Fortiex. $189 \%$. 50 pp.. 3 pls.

WS 12. Undergraund waters of soulheastern Nebraska, by N. H. Darton. 1898.56 pu, \&1 pls.

WS 21. Wells of northern Indiana, by Frank Leverett. 1899.82 pp., 2 pls.

WS 26. Wells of southern Indiana (continustion of No. 21), by Frank Lererett. 1899. 6. pp.

WS 30. Water resources of the Lower Peninsula of Michigan, by A. C. Lane. 1899.97 pp.; i pls.

WS 31. Lower Michigan mineral waters, by A. C. Lane. 1899.97 pl., 4 pls,

WS 34. Geology and water resoures of a portion of southeasteru South Dakota, by J. E. Todd. 1900, 34 pp., 15 pls.

WS 53. G6 alogy and water resources of Nez Perceg County, Idaho, Pt. I, by I. C. Russell. 1901. $80 \mathrm{pp}, 10 \mathrm{pls}$.

WS 54. Gejlogy and water resourees of Nez Perces County, Idaho, Pt. II, by I. C. Ruseell. 1901. 8i-141 pp.

WS 55. Coology and water resources of a portion of Yakima County, Wash., by G . A. Smith. 1901. $68 \mathrm{pp}, 7 \mathrm{pls}$.

WS $5 \pi$. Preliminary list of deep borings in United , tates, Pt. I, by N. H. Darton. 19ne. 10 pp.

WS 59). Development and application of water in srutharn Califoruis, Pt. I, hy J. B. Lippincott. 1902. $95 \mathrm{ppo}, 11 \mathrm{pls}$.

WS 61. Development and application of water in southeru California, Pt. II, by J. B. Lippincott. 1902. Qu-140 pp.

WS 01. Prelimivary liat of deep borings in Uniteil States, Pt. II, by N. H. Darton. 190z. 67 pp.

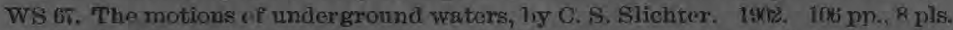

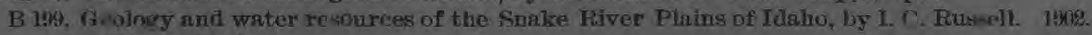
$192 \mathrm{pp}, 25 \mathrm{pls}$.

WS W. Water resourens of Mololoai, Hawailin Islands, by Waldenar Lindgren. 2903. 62 pp., 4 p's.

WS 72. Preliminary report on arterian basins in southwestern Iduho and suutheastern Oregon, by I. C. Rurie11, 1908. 53 pp., 2 pls.

PP 17. Prelimiurry report on the geology and waker zegonrees of Nebraska west of the one hundred and third meridian, by N. H. Darton. 1908 , $69 \mathrm{pp} .43$ pls.

WS 90. Genlogy and water resources of part of the lower James River Valley, Sonth Dakota, by J. E. Toda and C. M. Hall. 1904. 47 pp., 23 pls.

The following papr rs also relate to this subject: Underground wsters of Arkansas Valley in eastern Colorado, Ly G. K. Gilbert, in Seventeenth Annual, Pt. II; Preliminary rejort on artosisn waters of a portion of the Dakotas, by N. H. Darton, in Seventeenth Amuul, Pt. II; Writer resources of Ilinols, hy Frank Lererett, in Sevonteonth Annual. Pt. II; Watur resourcas of Indiane and Ohio, by Frank Levervtt, in Eightenth Annual, Pt. IV: New developments in well boring and irrightion in eastern South Dakotr, by N. H. Darton, in Eightoeuth Anunal, Pt. IV; Rock waters of Ohio, by Edward Orton, in Nineteonth Ammual, Pt. IV; Artakian well prospects in the Atlantic Coastal Plain region, by N. H. Darton, Bulletin No. 12\%.

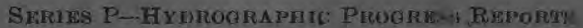

Progress reports may be found in the following publieations: For 1883-s9, Tenth Ammual, Pt. II; for 1889-9l, Dleventh Annus1, Pt. II: for 1890-91, Twelfth Amnual, Pt. II; Enr 1891-412, Thirteenth Ammual, Pt. III; for 1899-94, Bulletiu No. 13I; for 1895, Bulletin No. 14; for 1893, Eighteonth Annual, Pt. IV, WS 11; for 1S97, Nineteenth Anuual, Pt. IV, WS 15, 16; for 18ne, Twentieth Annual, Pt. IV, WS 27, 28; for 1899, Twenth-first Anmual, Pt. IV, WS 35-58; for 1900, Twenty-second Annual, Pt, IV, WS 47-5\%; for 1901. WS 65, 66, 75: for 1902, WS ds- 5 .

Correspondence should be addressed to

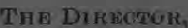

UNITED STATES G FULOQICAL SURVTY,

IRR $96-4$ W ASEUNGTON, D, C:

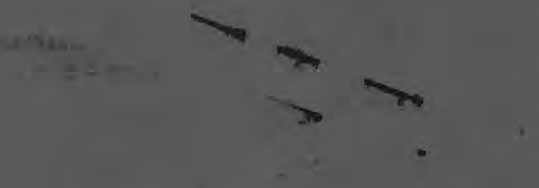

